\title{
AVALIAÇÃO CEFALOMÉTRICA PÓS-DISTALIZAÇÃO REALIZADA POR MEIO DO APARELHO PENDULUM, EM PACIENTES EM TRATAMENTO ORTODÔNTICO COM APARELHO FIXO
}

Fernanda Angelieri

\begin{abstract}
Dissertação apresentada à
Faculdade de Odontologia de Bauru, Universidade de São Paulo, como parte dos requisitos para a obtenção do título de Mestre em Odontologia, área de Ortodontia.
\end{abstract}

(Edição revisada)

Bauru

2002 


\section{AVALIAÇÃO CEFALOMÉTRICA PÓS-DISTALIZAÇÃO REALIZADA POR MEIO DO APARELHO PENDULUM, EM PACIENTES EM TRATAMENTO ORTODÔNTICO COM APARELHO FIXO}

\section{Fernanda Angelieri}

Dissertação apresentada à

Faculdade de Odontologia de Bauru, Universidade de São Paulo, como parte dos requisitos para a obtenção do título de Mestre em Odontologia, área de Ortodontia.

(Edição revisada)

Orientador: Prof. Dr. Renato Rodrigues de Almeida

Bauru 
Angelieri, Fernanda

An43a Avaliação cefalométrica pós-distalização realizada por meio do aparelho Pendulum, em pacientes em tratamento ortodôntico com aparelho fixo / Fernanda Angelieri Bauru, 2002.

170p.: il.; $29,7 \mathrm{~cm}$.

Dissertação. (Mestrado) - Faculdade de Odontologia de Bauru.

USP.

Orientador: Prof. Dr. Renato Rodrigues de Almeida

Autorizo, exclusivamente para fins acadêmicos e científicos, a reprodução total ou parcial desta dissertação/tese, por processos fotocopiadores e outros meios eletrônicos.

Assinatura:

Data:

Projeto de pesquisa aprovado pelo Comitê de Ética em Pesquisa da Faculdade de Odontologia de Bauru, Universidade de São Paulo, em reunião realizada no dia 27 de abril de 2000. 


\section{FERNANDA ANGELIERI}

07 de maio de 1977

1995-1998

2000

Associações
Nascimento

Curso de Odontologia -

Faculdade de Odontologia de

Bauru, Universidade de São

Paulo - Bauru-SP.

Curso de Pós-graduação em Ortodontia, em nível de Mestrado, na Faculdade de Odontologia de Bauru, Universidade de São Paulo.

Associação Paulista de Cirurgiões Dentistas 


\section{DEDICATÓRIA}




\section{A D eus, pelo amor, luz}

e, principalmente, por colocar pessoas

tão maravilhosas em minha vida,

imprescindívess para a realização

deste estudo. 


\section{A os meuspais,}

\section{V ergínio eM aria C laudete,}

meus verdader ros metres, que me ensinaram que com amor, coragem e persever ança conquistamos nossos objetivos, tornandonosmelhoresa cada dia, aprendendo a artede viver e ser feliz; 
A os estimadosirmãos,

\section{D anida eF ábio,}

pela confiança, companheirismo e amizade constantes,

\section{E ao querido $\mathbf{G}$ lauco,}

pelo apoio, compreensão e

paciência na espera por este momento,

D edico etetrabalho, com meu mais profundo afte. 
AGRADECIMENTOS 


\section{M eus sincerosagradecimentos,}

A o meu orientador,

\section{P rof. D r. R enato R odrigues deA Imeida}

pela orientação segura durante a realização deste trabalho, pelos ensinamentos transmitidos e, principalmente, pela confiança em mim depositada; 
A OC oordenador do C urso deM etrado,

\section{P rof. D r. G uilhermedosR eisP ereira J anson}

pela seriedade ededicação com que conduziu todo o curso, inclusive pelas exigências requeridas, que nos mostram, hoje, nossas

verdaderas capacidades, 


\section{$A$ os demais $P$ rofessores $D$ outores}

\section{A rnaldo P inzan,}

D écio $R$ odrigues $M$ artins,

J oséf ernando C astanha H enriques,

M arcosR obertodef reitas,

pela convivência netes anos, pelos ensinamentos e pela amizade. 
A gradeço ainda,

A todos os meus familiares, em especial, aos meus avós H ermínio es anta, Vegǵnio e A delina (in memorian) e aos tios, I da eP aulo, pelo apoio e confiança nos momentos mais difícés,

À $s$ minhas grandes amigas, C elinha, $\mathbf{R}$ gjane, $\mathbf{S}$ andra $e$ H doíza, pelo carinho eamizade sincera;

À S amigas, T ka, $\mathbf{M}$ irda, $\mathbf{A}$ na $\mathbf{P}$ aula, $\mathbf{A}$ naligia, R ganeeJ osiane, que mesmo à distância, torciam por mim;

A o inestimável amigo D anid, pelo companhérismo esolicitude; A os demais amigos do C urso de $M$ estrado: D enise, $\mathbf{F}$ ábio, D aniele, K arina, F abrício, J oxé E duardo, J oxe N orbeto, M aria F enanda, A driana e Claúdia, pelos conhecimentos compartilhados e pela amizade firmada;

A os colegas do M estrado recente: $\mathbf{A}$ ngeda, $\mathbf{D}$ anide, $\mathbf{C}$ esso, L Eniana, $\mathbf{R}$ odrigo, $K$ arina, $C$ risina eA nalu;

A os amigos do D outorado: A na C arla, D anida $\mathbf{G}$ arib, F austo, $\mathbf{R}$ enatha, $P$ aulo, $D$ anilo, $K$ arina $C$ ruz, $K$ arina $V$ alle, A na C laúdia eA driano; 
A os funcionários da $\mathrm{D}$ isciplina de 0 rtodontia: T ereza $\mathrm{C}$ risina A Ives $C$ amaforte $D$ ucatti, $L$ uiz $S$ égio V ieira, $M$ aria J ox dos $S$ antosf ormenti, $V$ era $L$ úcia $R$ odrigues $P$ urgato $E$ anid $F$ rancisso R ascäoS emo, pelo auxílio constante;

A todos os funcionários da B iblioteca, em especial, à V aléria, pela correção das referências bibliográficas,

A os funcionários da $P$ ós $G$ raduação, especialmente à $\mathbf{G}$ mne, A urélio eA na, pela atenção e orientação;

A 0 P rof. D r. A rnaldo P inzan e família, pelo carinho e amizade;

A 0 amigo, A cáciof uziy, pela ajuda na realização deste estudo;

A os alunos da $G$ raduação e pacientes da $C$ línica de $P$ ós G raduação, pela contribuição na minha for mação;

A os pacientes pertencentes à amostra deste estudo, imprescindíveis para a realização do mesmo;

A $\quad$ o P rof. J osé $\mathbf{R}$ obeto $\mathbf{P}$ ereira $\mathbf{L}$ auriş pela elaboração da análise estatística; ao P rof. H édio R equena, pela correção gramatical eao querido colega, F ábioH enriquedeS á L étäo P inheiro, pela corr reção do abstract. 
E specialmente,

A $F$ aculdade de 0 dontologia de $B$ auru, $U$ niversidade de $S$ ão $P$ aulo, representada pelo $D$ iretor, P rof. D r. A ymar P avarini;

A 0 P rof. D r. L uiz F enando P egoraro, $P$ residente da C omissão de $P$ ós $G$ raduação da $F$ aculdade de 0 dontologia de B auru;

A O P rograma E qpeial de T reinamento, P E T , na pessoa do P rof. D r. E duardo B atista F ranco, pela experiência e ensinamentos adquiridos durante 0 curso de $G$ raduação, de inigualável importância para a carreira profissional queinicio;

A $F$ undaçäo de $\mathbf{A}$ mparo à $\mathbf{P}$ eqquisa do $E$ stado de $S$ ão P aulo, F A P ES P, pela concessão da bolsa de estudos;

E a todos, que de uma forma ou outra, me auxiliaram nesta caminhada. 
SUMÁRIO 


\section{SUMÁRIO}

Lista de figuras.....................................................................

Lista de tabelas........................................................................

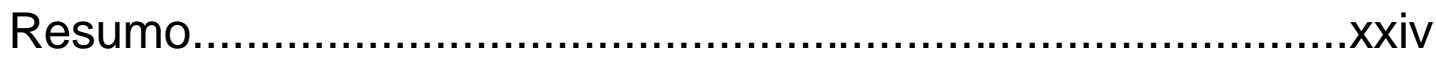

1 - Introdução................................................................. 1

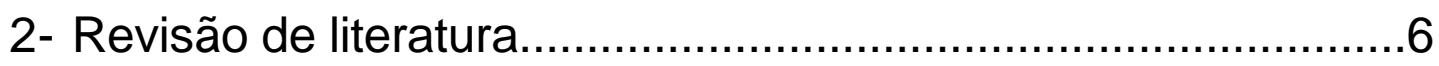

3- Proposição..................................................................

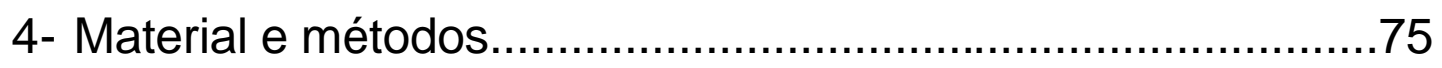

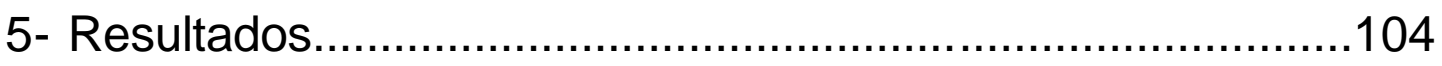

6- Discussão................................................................111

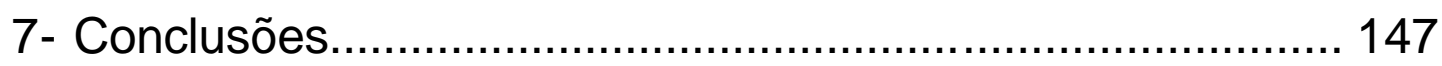

Referências bibliográficas..................................................151

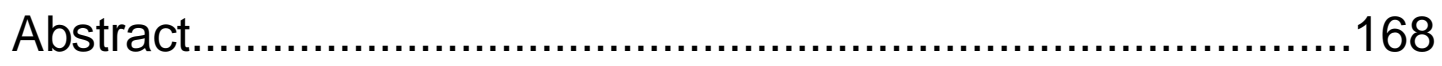

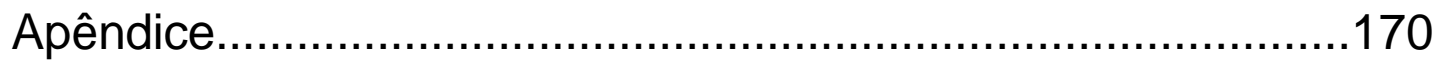




\section{LISTA DE FIGURAS}




\section{LISTA DE FIGURAS}

FIGURA 1 - Aparelho Pendulum demonstrando a préativação das molas TMA, preconizada por HILGERS, utilizada durante a distalização dos molares superiores

FIGURA 2 - Aparelho Pendulum instalado, com as molas TMA pré-ativadas em posição

FIGURA 3 - Aspecto extrabucal de um paciente da amostra 78 logo após a remoção do aparelho Pendulum

FIGURA 4 - Vista intrabucal do mesmo paciente na remoção 78 do aparelho Pendulum

FIGURA 5 - Botão de Nance instalado imediatamente após a 80 remoção de um aparelho Pendulum

FIGURA 6 - Aspecto intrabucal do paciente previamente citado na instalação do aparelho ortodôntico fixo

FIGURA 7 - Aspecto intrabucal do paciente anterior na 83 instalação do fio retangular superior passivo (os pré-molares superiores distalizaram parcialmente)

FIGURA 8 - Aspecto intrabucal de outro paciente da amostra, na fase pós-distalização dos molares superiores por meio do aparelho Pendulum 
FIGURA 9 - Vista intrabucal do paciente anterior no érmino do alinhamento e nivelamento do arco dentário superior. Observe que houve a distalização espontânea dos pré-molares superiores

FIGURA 10 - Telerradiografias em norma lateral tomadas 87 logo após a remoção do aparelho Pendulum e no final do alinhamento/nivelamento do arco dentário superior de um mesmo paciente

FIGURA 11 - Desenho anatômico

FIGURA 12 - Pontos cefalométricos

FIGURA 13 - Linhas e planos

FIGURA 14 - Grandezas angulares esqueléticas

FIGURA 15- Grandezas angulares e lineares do padrão facial

FIGURA 16 - Grandezas dentárias angulares e lineares 100

FIGURA 17 - Grandezas tegumentares 101

FIGURA 18 - Alterações sagitais na maxila 125

FIGURA 19 - Alterações sagitais na mandíbula 127

FIGURA 20 - Alterações na relação maxilomandibular 128

FIGURA 21 - Alterações esqueléticas verticais 130 
FIGURA 22 - Alterações dentárias verticais 132

FIGURA 23 - Alteraçõesnas inclinações dentárias 135

FIGURA 24 - Alterações dentárias sagitais 142

FIGURA 25 - Alterações no perfil mole 143 
LISTA DE TABELAS 


\section{LISTA DE TABELAS}

TABELA 1 - Resultado do teste " $\mathrm{t}$ " de Student para dados pareados

TABELA 2 - Resultado do teste " $\mathrm{t}$ " de Student para dados pareados e de Dalhbergh para análise do erro metodológico

TABELA 3 - Pacientes da amostra - gêneros e idades cronológicas

TABELA 4 - Grandezas angulares esqueléticas dos pacientes da amostra

TABELA 5 - Grandezas do padrão facial dos pacientes deste estudo

TABELA 6 - Grandezas referentes ao perfil mole dos pacientes da amostra

TABELA 7 - Grandezas verticais, sagitais e das inclinações dos incisivos superiores dos pacientes deste estudo

TABELA 8 - Grandezas sagitais, verticais e das inclinações dos primeiros pré-molares superiores dos pacientes desta amostra 
TABELA 9 - Grandezas verticais, sagitais e das inclinações dos primeiros molares superiores dos pacientes deste estudo 
RESUMO 


\section{RESUMO}

O aparelho Pendulum tem demonstrado uma alta efetividade na distalização dos molares superiores para a correção da relação molar de Classe II. Entretanto, muitos efeitos adversos tem sido observados: mesialização e inclinação para mesial dos pré-molares superiores; aumento da altura facial ântero-inferior e uma considerável inclinação para distal dos primeiros molares distalizados, tornando a distalização molar instável. A proposta deste estudo consistiu em avaliar a correção desses efeitos adversos em 23 pacientes ( 7 do gênero masculino e 16 do feminino), apresentando a idade inicial média de 15 anos e 1 mês, tratados por meio do aparelho ortodôntico fixo associado ao Botão de Nance e aparelho extrabucal, de uso noturno. Foram obtidas telerradiografias em norma lateral imediatamente após a remoção do aparelho Pendulum e no término do alinhamento/nivelamento dentários, num período médio de 1 ano. Os resultados obtidos foram submetidos ao teste $t$ de Student, para dados pareados. O ângulo ANB diminuiu em $0,52^{\circ}$ e a altura facial ântero-inferior aumentou em $0,88 \mathrm{~mm}$. Os incisivos superiores extruíram $0,51 \mathrm{~mm}$. Os primeiros pré-molares superiores verticalizaram $10,23^{\circ}$ e distalizaram $2,86 \mathrm{~mm}$, espontaneamente. Os primeiros molares superiores extruíram $0,73 \mathrm{~mm}$, mesializaram 1,2mm e verticalizaram $7,63^{\circ}$. Conclui-se que houve a correção dos principais efeitos adversos promovidos pelo aparelho Pendulum com o uso do aparelho ortodôntico fixo no prazo de um ano, contribuindo para a finalização satisfatória do tratamento ortodôntico. 
INTRODUÇÃO 


\section{INTRODUÇÃO}

Desde a sua classificação, a má oclusão de Classe II vem sendo estudada ostensivamente, principalmente em decorrência do acometimento estético que ocasiona e da significativa prevalência dentro da população. Segundo MOYERS; et al. ${ }^{96}$, em 1980, a Classe II apresenta-se como a má oclusão severa mais freqüentemente encontrada na população, fato confirmado por SILVA FILHO; FREITAS; CAVASSAN ${ }^{120}$, em 1989, que observaram que $42 \%$ das crianças naturais da cidade de Bauru-SP, na faixa etária de 7 a 11 anos, apresenta vam a má oclusão de Classe II.

Quando da sua classificação, em 1899, $\mathrm{ANGLE}^{7}$ definiu a má oclusão de Classe II como "a relação mesiodistal anormal dos arcos dentários, com o arco inferior posicionado dorsalmente ao superior, resultando na desarmonia das linhas faciais e dos incisivos". Desta forma, segundo $\mathrm{ANGLE}^{7}$, a etiologia da Classe II consistia somente no posicionamento posterior do molar inferior, sem qualquer atribuição ao molar superior ou aos componentes esqueléticos.

Com o advento da radiografia œfalométrica, verificoutse que, além do determinante dentário no desenvolvimento da má oclusão de Classe II, havia ainda, em certos casos, uma desarmonia esquelética entre os maxilares.

Vários foram os estudos encontrados na literatura desenvolvidos com 0 intuito de determinar quais as características esqueléticas e dentoalveolares prevalentes na má oclusão de Classe II.

A posição sagital da maxila permanece controversa. Alguns autores afirmam que há uma protrusão maxilar ${ }^{5,114,126}$, outros que se encontra bem posicionada em relação à base do crânio $0^{95,109,111}$ ou mesmo retruída. ${ }^{102}$ 
Observa-se o mesmo com a mandíbula. A grande maioria dos autores afirma a prevalência da retrusão mandibular $69,71,78,95,97,102,109,111$, ${ }^{126}$, porém alguns consideram a mandíbula bem posicionada em relação à base do crânio. ${ }^{5,114}$

Essa grande diversidade das opiniões dos autores reflete a ampla variação de formas em que a má oclusão de Classe II se apresenta na população. De acordo com BISHARA et al. ${ }^{17}$, esta variação torna-se compreensível à medida que diferentes interações entre os tecidos ósseos, dentários e moles coexistem na determinação da relação molar e dos caninos na Classe II.

Cientes da variabilidade existente na Classe II, MOYERS et al. ${ }^{96}$, em 1980, procuraram classificar os diversos tipos de má oclusão de Classe II. A partir do referencial do plano horizontal, seis subgrupos reconhecidos pelas letras $A, B, C, D, E$ e $F$ foram identificados. O tipo A consiste numa "pseudo-Classe II" ou Classe II dentária, sem qualquer componente esquelético. Os quatro tipos seguintes (B, C, D e E) constituemse em verdadeiras síndromes de Classe II esqueléticas graves, com características esqueléticas e dentárias, padrões morfológicos e de crescimento distintos. Quanto ao último tipo $(F)$, esse apresenta poucas características esqueléticas de Classe II, mas não se enquadra na má oclusão de Classe I, sendo a mais freqüente na população. De acordo com os autores, cada subgrupo da má oclusão de Classe II possui uma etiologia diferente, necessitando, por isso, de formas de tratamento distintas.

Atualmente, muitos são os recursos para o tratamento da Classe II, como os vários tipos de tração extrabucal, ortopedia funcional dos maxilares e extrações dentárias. Todavia, vale ressaltar que o sucesso do tratamento apresenta-se diretamente relacionado ao correto diagnóstico diferencial da Classe II e, assim, à indicação precisa da melhor forma de tratamento para sanar as necessidades individuais de cada caso. ${ }^{95,96}$ 
Para a Classe II dentária sem comprometimento esquelético (o tipo A de MOYERS et al. ${ }^{96}$ ), o tratamento mais indicado constitui-se na retração de todos os dentes superiores para uma relação molar, de caninos e de incisivos normais, sem qualquer alteração na relação esquelética, dimensão vertical ou comprometimento no arco dentário inferior, por meio da distalização dos molares superiores. ${ }^{96}$

Inicialmente, preconizoutse a utilização do aparelho extrabucal para a distalização dos molares superiores ${ }^{40}, 82,83$, seguido de outros aparelhos que dependiam excessivamente da colaboração do paciente: aparelhos removíveis com molas digitais associados ao aparelho extrabucal $^{35,53,76, \text {; arco de Wilson }}{ }^{67,98,128,129,130}$, dentre outros.

Contudo, verifica-se na literatura ${ }^{38,39,74}$ que a cooperação dos pacientes em Ortodontia apresenta-se como um fator altamente variável e cada vez mais insatisfatória clinicamente. Mc DONALD ${ }^{94}$, em 1973, afirmou que a severidade da má oclusão não se relaciona nem com a cooperação do paciente nem mesmo com o desejo de buscar o tratamento ortodôntico.

Como alternativa para 0 tratamento de pacientes não colaboradores, buscou-se 0 desenvolvimento de mecânicas que independem da colaboração desses.

Recentemente, houve um avanço considerável no desenvolvimento de aparelhos distalizadores de molares superiores que independem da colaboração dos pacientes: os magnetos repelentes ${ }^{59,} 58,72$; as molas de níquel-titânio ${ }^{50,57,104}$; os fios de níquertitânio superelásticos ${ }^{54}$, 77, 86, 90; o aparelho de Nance modificado ${ }^{106,108}$; o Jones $\mathrm{Jig}^{67,76,115,121,123}$; o Distal Jet ${ }^{25,26,34,99,107}$; o aparelho Pendulum 29, 30,31, 36, 49, 52, 70, 87dentre outros.

O aparelho "Pendulum" foi desenvolvido por HILGERS ${ }^{70}$, em 1992. Sua principal função consiste na distalização dos primeiros e segundos molares superiores, em pacientes não colaboradores. É um aparelho dentomuco-suportado, composto por um Botão acrílico de Nance localizado no 
palato, com a finalidade de ancoragem e molas de titânio-molibdênio, que produzem uma força moderada e contínua sobre os molares.

Vários autores comprovaram a eficácia do aparelho Pendulum na correção da má oclusão de Classe $\|^{29,30,31,36,49,52,87}$. Entretanto, apesar da obtenção da distalização efetiva dos molares superiores, ocorrem simultaneamente alguns efeitos adversos, como: mesialização e inclinação para mesial dos pré-molares superiores; acentuada inclinação para distal dos molares distalizados; extrusão dos pré-molares; aumento da altura facial ântero-inferior devido à rotação em sentido horário da mandíbula; aumento da distância intermolares superiores; protrusão e vestibularização dos incisivos superiores; protrusão do lábio superior; aumento do trespasse horizontal e redução do vertical. ${ }^{29,30,36,49,52}$

Acredita-se que esses efeitos adversos resultantes do processo de distalização dos molares superiores sejam corrigidos durante o tratamento ortodôntico com aparelho fixo. Contudo, observa-se na literatura atual raros estudos abordando o tratamento ortodôntico pós-distalização dos molares superiores por meio dos aparelhos intrabucais.

O objetivo deste estudo consiste na avaliação dos efeitos esqueléticos, tegumentares e dentários pós-distalização dos molares superiores com 0 aparelho Pendulum, em pacientes em tratamento ortodôntico fixo, pela análise de telerradiografias em norma lateral imediatamente após a remoção do aparelho distalizador e no término do alinhamento e nivelamento do arco dentário superior. 
REVISÃO DE LITERATURA 


\section{REVISÃO DE LITERATURA}

\section{1 - A CLASSE II}

Em 1899, ANGLE ${ }^{7}$ propôs um dos primeiros conceitos de oclusão na dentadura normal baseando-se nos primeiros molares superiores. As más oclusões foram classificadas de acordo com a relação oclusal apresentada entre o primeiro molar superior e o primeiro molar inferior em Classe I, II ou III. Como o primeiro molar superior era sempre considerado como bem posicionado no complexo craniofacial, ANGLE ${ }^{7}$ caracterizou a má oclusão de Classe II como um relacionamento distal do arco dentário inferior em relação ao superior.

Com o advento da radiografia cefalométrica, observourse que, além do determinante dentário, havia ainda fatores esqueléticos envolvidos no desenvolvimento da má oclusão de Classe II.

\subsection{1 - Prevalência da má oclusão de Classe II}

Assim, no decorrer do tempo, muitos autores procuraram estabelecer as principais características cefalométricas encontradas na Classe II, principalmente por essa má oclusão representar uma significativa porcentagem dos casos tratados nos consultórios odontológicos. De acordo com MASSLER; FRANKEL ${ }^{93}$, em 1951, a proporção entre Classe I e Classe II, em um estudo da prevalência das más oclusões em adolescentes americanos entre 14 e 18 anos de idade compreendeu 3:1, respectivamente. SILVA FILHO; FREITAS; CAVASSAN ${ }^{120}$, em 1989, observaram uma freqüência de $42 \%$ de Classe II, nas crianças naturais da cidade de Bauru SP, na faixa etária de 7 a 11 anos. 


\subsection{2 - Características cefalométricas da má oclusão de Classe II}

As características cefalométricas da Classe II foram investigadas por OPPENHEIN ${ }^{102}$, em 1928, que constatou prevalência da falta de desenvolvimento mandibular, apesar da maxila ter-se apresentado em menor tamanho nos casos por ele avaliados.

Durante muito tempo a distoclusão dos molares inferiores foi considerada uma deficiência de crescimento e/ou retroposicionamento da mandíbula. Um dos primeiros autores a discordar desse fato foi ANDERSON $^{5}$, em 1946, que demonstrou, ao avaliar casos de Classe II, que em muitos deles, a mandíbula apresentava-se normal com a maxila posicionada anteriormente, criando uma aparente distoclusão dos molares inferiores.

A partir de então, a discordância de dados apresentourse como uma constante na literatura. RENFROE ${ }^{109}$, em 1948, concluiu que a retrusão mandibular consistiu na característica mais comumente encontrada na amostra de Classe II por ele avaliada, porém a mandíbula encontrava-se em tamanho normal. Esse dado foi corroborado por RIEDEL ${ }^{111}$, quatro anos mais tarde, que identificou um posicionamento mandibular retrognata e uma posição neutra da maxila. Em 1973, HITCHCOCK ${ }^{71}$ concluiu que as características cefalométricas observadas na Classe II, divisão 1, constituem-se numa protrusão dos dentes ântero-superiores associada à retrusão mandibular.

Com o objetivo de avaliar a freqüência com que ocorrem as principais características da Classe II e a abordagem terapêutica mais adequada, Mc NAMARA JUNIOR ${ }^{95}$, em 1981, analisou telerradiografias em norma lateral de 277 crianças entre 8 e 10 anos. O autor observou que a má oclusão de Classe II pode resultar de várias combinações entre os componentes esqueléticos e dentários. Porém, as características mais prevalentes encontradas em sua amostra foram: posição maxilar retruída ou neutra; dentes ântero-superiores protruídos; retrusão mandibular; dentes 
ântero-inferiores bem posicionados e desenvolvimento vertical excessivo do terço inferior da face.

Já ANDERSON; POPOVICH ${ }^{4}$, em 1983, associaram à Classe II, divisão 1 uma base craniana mais larga, em que a altura craniana superior apresentava-se aumentada e o ângulo da base do crânio apresenta-se maior.

As características cefalométricas de 50 jovens brasileiros possuindo Classe II, divisão 1, com idades variando de 9 a 15 anos, foram analisadas por VALE; MARTINS ${ }^{126}$, em 1987. Observaram que a posição maxilar apresentourse bastante variável, com discreta tendência ao prognatismo; os incisivos superiores apresentaram-se protruídos; a posição mandibular mostrou-se com grande variabilidade, com maior prevalência do retrognatismo mandibular; os incisivos inferiores apresentaram-se retruídos e houve um desenvolvimento vertical excessivo, representado pela altura facial ântero-inferior aumentada.

Corroborando com os resultados de Mc NAMARA JUNIOR ${ }^{95}$, KARLSEN $^{78}$, em 1994, verificou uma mandíbula retrognata e de comprimento diminuído, com acentuada tendência de subdesenvolvimento vertical dos molares superiores e inferiores, em pacientes possuindo Classe II, divisão 1, com ou sem sobremordida profunda.

Contudo, ROSEMBLUM ${ }^{114}$, em 1995, criticou severamente o estudo realizado por Mc NAMARA JUNIOR ${ }^{95}$. O autor afirmou que as medidas mais confiáveis para o correto diagnóstico da Classe II baseiam-se no Plano de Frankfurt e não na linha SN (utilizada por Mc NAMARA JUNIOR ${ }^{95}$ ), que demonstraram prevalência da protrusão maxilar em 56,6\% dos casos contra $26,7 \%$, de retrusão mandibular, ao contrário dos dados apresentados por Mc NAMARA JUNIOR ${ }^{95}$.

O crescimento na Classe II foi analisado por BISHARA et al. ${ }^{17}$, em 1997, que compararam longitudinalmente as alterações dentofaciais em indivíduos com Classe II, divisão 1, não tratados e jovens com oclusão 
normal, entre as dentaduras decídua e permanente. Constataram que a tendência de crescimento apresentou-se similar entre os grupos, com exceção da protrusão do lábio superior. Porém, houve diferenças significativas na magnitude do crescimento, com maior convexidade esquelética e tegumentar na Classe II, divisão 1 , acompanhada de maior tendência à retrusão mandibular. Já pela comparação transversal, observaram-se muitas diferenças no comprimento e posição mandibulares nas idades precoces, não mais verificadas nas idades mais avançadas. Estes dados sugerem que provavelmente há um período de crescimento mandibular tardio na Classe II, quando comparada aos indivíduos normais.

Com o intuito de comparar as más oclusões de Classe II, divisão 1 e Classe II, divisão 2, PANCHERZ; ZIEBER; HOYER ${ }^{103}$, em 1997, realizaram um estudo com crianças nas idades de 8 a 10 anos e 11 a 13 anos. Os resultados revelaram que ambas não são entidades clínicas simples e, com exceção da posição dos incisivos superiores, não se constatou nenhuma outra diferença morfológica entre elas. Independentemente da idade, ampla variação na morfologia dentoesquelética prevaleceu em ambas as más oclusões.

HENRIQUES et al. ${ }^{68}$, em 1998, avaliaram longitudinalmente 25 jovens apresentando má oclusão de Classe II, divisão 1, dos 9 aos 12 anos, não tratados. Verificaram que em $75 \%$ dos casos a mandíbula apresentout se retruída, enquanto a maxila variou entre retruída, bem posicionada e protruída. O padrão de crescimento denotou variabilidade, com distribuição uniforme de indivíduos com predominância de crescimento vertical, horizontal e equilíbrio dos vetores. Os incisivos superiores apresentaram-se geralmente protruídos e tenderam a perpetuar esta característica com o crescimento.

Observa-se na literatura que os resultados pertinentes às características principais da Classe II divergem bastante, podendo estar associada a uma ou à combinação das seguintes condições: 
- protrusão maxilar esquelética adicionada ou não a um tamanho maxilar aumentado;

- protrusão dentária superior;

- retrusão mandibular esquelética associada ou não a uma mandíbula de tamanho diminuído;

- retrusão dentária inferior;

- $\quad$ ângulo da base do crânio obtuso.

A falta de consenso sobre as características dentofaciais da Classe II é um indicador da ampla variabilidade dentro da população ${ }^{17}$. Esse aspecto torna-se compreensível à medida que diferentes interações entre os tecidos ósseos, dentários e moles levam à discrepância dentária descrita como distoclusão. ${ }^{17}$

\subsection{3 - Classificacão da má oclusão de Classe II}

Cientes da variabilidade existente na Classe II, MOYERS et al. ${ }^{96}$, em 1980, utilizaram uma combinação de programas computadorizados e de diversas análises para identificar e classificar os diversos tipos de Classe II. A partir da análise das telerradiografias de uma ampla amostra de indivíduos considerados Classe II (dentariamente) por três ortodontistas, os autores propuseram duas classificações: uma baseada nas variáveis cefalométricas horizontais e outra nas verticais, havendo a combinação de ambas para cada indivíduo. A partir das variáveis horizontais, seis subgrupos foram identificados:

Tipo A: não possui características esqueléticas da Classe II, apenas dentárias. Os dentes superiores apresentam-se protruídos, o que resulta na Classe II dentária.

Tipo B: é uma Classe II esquelética. A mandíbula apresenta-se com tamanho normal e bem posicionada, mas a maxila encontra-se protruída. 
Tipo C: tipo severo de Classe II esquelética. Tanto a mandíbula como a maxila apresentam-se retruídas, devido a um tamanho diminuído. Os incisivos inferiores estão inclinados para vestibular e os incisivos superiores ou apresentam-se verticalizados ou inclinados para vestibular, dependendo do tipo vertical que o indivíduo possua. O perfil facial é acentuadamente convexo.

Tipo D: Classe II esquelética devido a uma mandíbula de tamanho diminuído associada a uma maxila normal ou levemente diminuída. Os incisivos inferiores apresentam-se inclinados para lingual ou verticalizados, enquanto que os superiores apresentam-se inclinados acentuadamente para vestibular.

Tipo E: há uma biprotrusão dos maxilares. Os dentes superiores e inferiores posicionam-se para anterior em relação às suas bases ósseas e os incisivos demonstram uma acentuada inclinação para vestibular.

Tipo F: É o grupo mais heterogêneo com tendências suaves de Classe II esquelética. A mandíbula apresenta-se diminuída e a maxila também pode ser diminuída. Devido à sua grande variabilidade, seria mais fácil descrever que o grupo $\mathrm{F}$ compreende os casos bem suaves dos tipos B, C, D ou E. O tipo $\mathrm{F}$ é o grupo mais freqüente da amostra.

De acordo com os autores, essa classificação proporciona um diagnóstico correto e preciso da má oclusão de Classe II, resultando na escolha do tratamento mais indicado. Os tipos B e E, por exemplo, corresponderam a menos de $20 \%$ da amostra, em que o uso do aparelho extrabucal estaria bem indicado. Já para os tipos C, D e F, representando mais de $50 \%$ da amostra, um aparelho ortopédico para estimular o crescimento mandibular seria mais indicado do que o aparelho extrabucal.

Portanto, a má oclusão de Classe II consiste em uma entidade clínica bastante abrangente, que deve ser avaliada criteriosamente de maneira individual, não podendo ser simplificada em apenas um tipo facial característico. 


\section{2 - FORMAS DE TRATAMENTO PARA A CLASSE II}

Muitas terapêuticas apresentam-se disponíveis aos ortodontistas para o tratamento da Classe II. Essas incluem os diferentes aparelhos extrabucais, aparelhos ortopédicos funcionais, diversos protocolos de extrações dentárias e, mais atualmente, os distalizadores de molares superiores. ${ }^{95,96} \mathrm{O}$ conhecimento e o correto diagnóstico da Classe II tornamse imprescindíveis, na medida em que cada aparelho difere nos efeitos promovidos na estrutura craniofacial, inclusive redirecionando o crescimento nas regiões envolvidas. Assim, as diferentes terapêuticas afetam a estrutura craniofacial de várias formas e a variedade disponível de aparelhos para 0 tratamento da Classe II reflete a diversidade de etiologias. ${ }^{94} \mathrm{~A}$ escolha do melhor tratamento depende da idade e do diagnóstico preciso das alterações inerentes a cada paciente apresentando uma relação de Classe II dentária. ${ }^{95,96}$

De maneira geral, diante de uma Classe II esquelética, em idade precoce e, preferencialmente, com padrão de crescimento equilibrado ou horizontal, indica-se o tratamento ortopédico. Se o fator problemático for a protrusão maxilar, pode-se empregar os diferentes tipos de aparelhos extrabucais (AEB), dependendo do padrão de crescimento do paciente; ou mesmo, na dentadura mista precoce, o splint maxilar ou AEB conjugado, com o intuito de restringir o crescimento maxilar. ${ }^{75}$

Se a Classe II estiver presente às expensas de uma retrusão mandibular, na fase de crescimento do paciente, indica-se o tratamento ortopédico que objetiva estimular o crescimento mandibular por meio dos aparelhos ortopédicos funcionais, que podem ser: ativador, bionator, Herbst, Bimler, dentre outros. ${ }^{75,95}$

Em idade mais avançada, na ausência de crescimento, uma Classe II esquelética acentuada somente será corrigida corretamente por meio da cirurgia ortognática associada ao tratamento ortodôntico. Porém, 
diante de uma Classe II esquelética de grau suave a moderado, e que, portanto, tolera uma "camuflagem ortodôntica", o tratamento de eleição será por meio das extrações. Geralmente, em se tratando da Classe II, o protocolo das extrações restringe-se somente aos primeiros pré-molares superiores ou conjuntamente aos segundos ou primeiros pré-molares inferiores, na presença de apinhamento no arco dentário inferior. ${ }^{105}$

\subsection{1 - Tratamento da Classe II com extração de pré-molares}

Existe grande controvérsia entre os autores com relação ao dilema do tratamento por meio das extrações ou não. As extrações dentárias, por razões ortodônticas, tornaram-se corriqueiras no final do século XIX, quando o tratamento usualmente consistia apenas na extração de dentes severamente mal alinhados. Para $\mathrm{ANGLE}^{8}$, no início do século $\mathrm{XX}$, as extrações destruíam a possibilidade da oclusão e estética ideais, pois ambas requeriam a presença de todos os dentes na cavidade bucal. Assim sendo, as extrações seriam desnecessárias e contra-indicadas no tratamento ortodôntico "moderno", já que a função estabilizaria os dentes em suas novas posições.

Com o passar do tempo, tornou-se clara a recidiva da expansão dos arcos dentários realizada por ANGLE $^{7}$, apesar dos esforços para produzir a função ideal. Na década de 1930, as extrações foram reintroduzidas e apresentadas por TWEED ${ }^{125}$, em 1945, com vistas a diminuir ou anular as recidivas. Nessa época, somente a técnica Edgewise modificada por Tweed proporcionava controle suficiente da posição radicular na fase do fechamento dos espaços das extrações. Já por volta de 1960, quando a técnica de Begg foi introduzida nos Estados Unidos, muitos ortodontistas que não trabalhavam com a técnica Edgewise puderam adotar uma mecânica de controle radicular para o tratamento com extrações. Em razão disso, a porcentagem de tratamentos ortodônticos realizados por meio das extrações alcançou seu ápice. Desde então, a porcentagem das 
extrações vem declinando notoriamente e essas têm sido planejadas com maior cautela. ${ }^{105}$

Contemporaneamente, a decisão entre extrair ou não associase significantemente ao padrão de crescimento facial do paciente. SASSOUNI; NANDA ${ }^{116}$, em 1964, recomendaram que os pacientes com tendência ao crescimento horizontal admitem um tratamento sem extrações, porém para os pacientes dolicofaciais indicam-se as extrações dentárias. Isso porque se acredita que o tratamento sem extração provoca uma rotação horária da mandíbula, levando a um aumento da altura facial ântero-inferior (AFAl), prejudicial para os pacientes dolicofaciais. Há uma concordância de que as extrações associam-se à rotação anti-horária da mandíbula e, então, à diminuição da AFAI.

Para comprovar essa teoria, CHUA; LIM; LUBIT ${ }^{37}$, em 1993, avaliaram pacientes Classe I e II tratados com a extração dos quatro primeiros pré-molares e sem extração, comparados a um grupo controle, não tratado ortodonticamente. Os pacientes foram tratados por ortodontistas em seus consultórios particulares. Houve nítida predileção pelos pacientes braquifaciais para o tratamento sem extração e dos dolicofaciais para as extrações dentárias. A mecânica sem extrações baseou-se no uso do AEB, elásticos de Classe II ou expansão. Os resultados mostraram que 0 tratamento sem extrações associou-se a um significativo aumento da AFAI, devido a uma rotação horária mandibular. Entretanto, o tratamento com extrações não se correlacionou com uma esperada diminuição da AFAl, talvez devido ao tempo de tratamento mais prolongado, que proporcionou um maior crescimento vertical desses pacientes no período avaliado. Assim, os autores concluíram que não houve diferença estatisticamente significante entre os tratamentos com ou sem extrações, com relação às alterações na AFAl.

Ao comparar as alterações no perfil facial em pacientes Classe II, divisão 1, tratados ortodonticamente com a extração de quatro prémolares e um grupo tratado sem extração, por meio dos aparelhos 
ortopédicos funcionais, BISHARA et al. ${ }^{16}$, em 1995, concluíram que a decisão entre extrair ou não correlaciona-se à protrusão labial superior em primeira instância e, secundariamente, à severidade do apinhamento. Os autores observaram que a convexidade esquelética e tegumentar diminuiu significantemente no grupo tratado com extrações; além disso, os lábios superior e inferior encontravam-se mais retruídos e os incisivos superiores e inferiores apresentavam-se mais retruídos e verticalizados comparado ao grupo tratado sem extrações dentárias. Essas diferenças entre os grupos permaneceram constantes durante o período de contenção.

Em 1982, OLIVER ${ }^{101}$ encontrou alta correlação entre a retração dos incisivos e a labial, quando os lábios eram finos e hipertensos. Contudo, se os lábios apresentavam-se espessos e hipotensos, a correlação apresentava-se baixa. O autor atribui este fato a um possível suporte inerente aos lábios espessos, o que os torna independentes da retração dentária ocasionada pelo tratamento com extrações dentárias.

A estabilidade do tratamento da Classe II, divisão 1 com extração de quatro pré-molares comparada a um grupo tratado sem extrações, por meio do uso do AEB cervical e elásticos de Classe II ocasionais, em pacientes com idade média de 11,2 anos, com padrões verticais normais, foi avaliada por FIDLER et al. ${ }^{46}$, em 1995. Decorridos 14 anos da finalização da terapêutica, os autores concluíram que tanto os pacientes submetidos às extrações como ao tratamento sem extrações demonstraram estabilidade dentária e esquelética, não diferentes estatisticamente. Segundo os autores, os fatores mais importantes para a estabilidade a longo prazo consistem na função e oclusão satisfatórias (com intercuspidação adequada) ao final do tratamento. O tipo de aparelho utilizado ou a realização de extrações para a obtenção de um bom relacionamento oclusal possuem menor importância na estabilidade dos resultados obtidos. Além disso, a inibição do crescimento maxilar para anterior por meio do AEB permaneceu estável, apesar dos pacientes demonstrarem um crescimento pós-tratamento bastante significativo. 


\subsection{2 - Tratamento da Classe II com extração dos $2^{\text {os }}$ molares superiores}

Outros protocolos de extrações foram propostos na literatura para o tratamento da Classe II. O tratamento por meio da extração dos segundos molares superiores em vez dos primeiros pré-molares foi sugerido primeiramente por GRABER ${ }^{61}$, em 1955. Posteriormente, em 1969, o mesmo autor ${ }^{62}$ revisou a extração dos segundos molares superiores no tratamento da Classe II. As indicações para esse tratamento compreendem as más oclusões de Classe II em que a ortopedia já não é mais possível devido à idade do paciente, em que um crescimento mandibular seria necessário; presença dos incisivos superiores acentuadamente inclinados para vestibular, com ausência de espaços no arco superior; sobremordida mínima; terceiros molares superiores presentes e em boa posição e formação no arco dentário. Contra-indica-se a extração dos segundos molares superiores na presença de uma Classe II esquelética severa (com acentuada desarmonia entre as bases ósseas); incisivos superiores inclinados para lingual, sem espaço no arco dentário e sobremordida profunda demasiadamente severa. A mecânica compreende o uso de um AEB nos primeiros molares superiores associado ao uso de elásticos de Classe II por 4 a $6 \mathrm{~h} / \mathrm{dia}$. Os incisivos superiores encontram-se interligados aos primeiros molares superiores por meio de um arco principal para que todo o arco dentário superior se remodele para distal, minimizando ainda a inclinação para distal dos primeiros molares superiores. Torna-se imprescindível a utilização de um arco lingual inferior com extensão na face oclusal dos segundos molares inferiores, de maneira a impedir a extrusão desses até que os primeiros molares ocupem os espaços dos segundos molares extraídos.

MAGNESS $^{88}$, em 1986, afirmou que a presença, a posição e a forma dos terceiros molares superiores devem ser confirmadas radiograficamente previamente à extração dos segundos molares. A posição ideal dos terceiros molares superiores consiste numa leve distoangulação, o 
que permite uma rotação para mesial durante sua irrupção. Se os terceiros molares aparentemente não se apresentarem bem formados, a extração deve ser postergada ou outro plano de tratamento determinado. Os pacientes ideais para este tipo de tratamento possuem bom perfil facial, convexidade suave, padrão braquicefálico e a presença de potencial de crescimento. Somente uma pequena parcela dos pacientes ortodônticos se beneficiariam da remoção dos segundos molares superiores. Entretanto, se devidamente indicada, esta terapêutica proporciona o sucesso do tratamento ortodôntico com estética satisfatória para o paciente.

Os resultados obtidos após o tratamento da Classe II realizado por meio da extração dos segundos molares superiores foram avaliados por BASDRA; STELLZIG; KOMPOSCH ${ }^{12}$, em 1996, atentando para o posicionamento final dos terceiros molares superiores irrompidos. Tanto 0 SNA como a inclinação e a protrusão dos incisivos superiores e do lábio superior diminuíram significantemente. Conjuntamente, o SNB apresentou suave aumento, o que contribuiu para a correção da Classe II. Todas essas alterações proporcionaram modificações significativas no perfil facial, com a diminuição da sua convexidade. Ao final do tratamento, todos os terceiros molares superiores haviam irrompido e apresentavam-se bem posicionados no arco dentário. Os autores sugeriram que a época ideal para a extração dos segundos molares superiores compreende aquela em que os terceiros molares superiores encontram-se radiograficamente ao nível da junção cemento-esmalte dos segundos molares superiores, pois nessa fase ocorrerá uma irrupção rápida e um bom posicionamento dos terceiros molares após a extração dos segundos molares superiores ${ }^{88}$, além da avaliação da sua posição e anatomia ser mais segura. ${ }^{88}$ Os autores reafirmaram as indicações propostas por GRABER ${ }^{61}$, incluindo como item importante o padrão de crescimento preferencialmente horizontal e um arco dentário inferior desprovido de apinhamento. As principais vantagens apresentadas pela extração dos segundos molares superiores consistem na distalização facilitada dos primeiros molares superiores ${ }^{88}$, sendo que a 
correção de uma Classe II completa com o uso do AEB pode ser obtida no período de 3 a 6 meses, dependendo da idade e colaboração do paciente; além do padrão de irrupção dos terceiros molares superiores apresentar-se de melhor predição comparado aos inferiores. As desvantagens observadas nesse tratamento foram: a grande quantidade de espaço criado (bem maior que aquele obtido pela extração dos pré-molares); necessidade da motivação e cooperação do paciente; o tempo de tratamento após a correção da Classe II pode tornar-se longo até a irrupção completa dos terceiros molares superiores.

ARAS $^{9}$, em 2000, apresentou um caso clínico tratado por meio da extração dos segundos molares superiores e da distalização dos primeiros molares superiores com um aparelho removível com molas digitais (ACCO) associado a um aparelho extrabucal de uso noturno. A paciente possuía todas as indicações para a extração dos segundos molares superiores: terceiros molares superiores bem formados e posicionados, perfil facial satisfatório e apinhamento suave no arco dentário inferior. Contudo o autor contra-indicou a extração dos segundos molares superiores em pacientes dolicofaciais. $O$ tratamento foi finalizado com sucesso, tendo como fator essencial a cooperação máxima da paciente.

$\mathrm{Na}$ realidade, a extração dos segundos molares superiores para o tratamento da Classe II permanece como uma controvérsia na literatura, embora quando realizada precocemente, apresente-se como uma alternativa viável para a não-extração dos pré-molares superiores, pois associada ao uso do AEB e/ou de mecânica de Classe II, facilita a distalização dos primeiros molares superiores. ${ }^{12,62,88}$

\subsection{3 - Tratamento da Classe II sem extracõos dentárias}

No decorrer do tempo, observa-se uma tendência bastante acentuada para um tratamento ortodôntico mais conservador, evitando ao máximo as extrações dentárias. PROFFIT ${ }^{105}$, em 1994, comprovou uma 
diminuição estatisticamente significante nos índices das extrações realizadas na Universidade da Carolina do Norte, USA entre 1968 e 1993. Em 1968, os tratamentos com extrações somavam $76 \%$ dos casos tratados e, em 1993 , somente $28 \%$. O declínio mais significativo ocorreu no tratamento da Classe I com apinhamento, sendo 50\% com extrações em 1963 e aproximadamente 10\%, em 1993. Já para o tratamento da Classe II, poucas alterações foram observadas, com índices não significantes estatisticamente, 16\% em 1968 e 8\% em 1993.

Recentemente, vários autores têm proposto tratamentos para a Classe II de forma a evitar as extrações dentárias. De acordo com MOYERS et al. ${ }^{96}$; CETLIN, TEN HOEVE ${ }^{35}$; e GIANELLY ${ }^{56}$, para a Classe II dentária, sem comprometimentos esqueléticos significativos, o tratamento mais indicado consiste na retração de todos os dentes superiores para uma relação de molares, de caninos e de incisivos normais, sem alterações acentuadas na relação esquelética, na dimensão vertical ou comprometimento do arco dentário inferior.

Um dos primeiros autores a abordar uma terapêutica sem extrações para o tratamento da Classe I e II com apinhamento e protrusão foram CETLIN; TEN HOEVE ${ }^{35}$, em 1983. Os principais objetivos clínicos constituíam: obtenção de espaço nos arcos dentários superior e inferior, intrusão dos incisivos superiores e preservação da ancoragem máxima durante o tratamento, evitando efeitos adversos no crescimento facial. Para a obtenção de espaço no arco dentário inferior foi utilizada uma placa lábioativa, que agiu movimentando os molares distalmente, além de aumentar a dimensão transversal do arco dentário. No arco dentário superior, almejout se o movimento de corpo para distal dos molares, essencial para evitar as recidivas para mesial. Para isso, utilizou-se de um aparelho removível com molas digitais de uso contínuo nos primeiros molares superiores, associado a um AEB de uso noturno, tração baixa ou alta, dependendo do padrão esquelético do paciente. A distalização dos molares levou, em média, 10 meses, com a colaboração fundamental do paciente. Após a obtenção dos 
espaços no arco dentário, os incisivos superiores foram retraídos e intruídos. Os autores concluíram que o tratamento sem extrações, quando bem indicado, proporciona ótimos resultados no que tange à estética, função, estabilidade e saúde bucal, sem alterar negativamente o potencial de crescimento facial.

\section{3 - A DISTALIZAÇÃO:}

Em 1998, GIANELLY ${ }^{66}$ afirmou que a distalização caracterizase pela movimentação para distal dos molares superiores no estágio inicial do tratamento, para converter a relação molar de Classe II em I. O próprio autor atentou, em entrevista realizada em 1996 , que, na presença de apinhamento na dentadura permanente associado a uma Classe I ou II, o tratamento por meio das extrações torna-se preferível, a menos que o perfil facial e/ou a profundidade da sobremordida o contra-indique ${ }^{55}$. Na má oclusão de Classe II com o arco dentário inferior em condições aceitáveis, pode-se iniciar o tratamento com a distalização dos molares superiores. Se não se observar progresso, parte-se então para a extração dos pré-molares superiores, exceto nos casos onde o perfil facial e a sobremordida profunda contra-indiquem esse procedimento.

O movimento distal dos primeiros molares superiores torna-se facilitado quando realizado antes da irrupção dos segundos molares superiores. Devido a isso, a época favorável para distalizar os molares compreende o período da dentadura mista. Indicam-se forças contínuas para a movimentação, já que essas movimentam os dentes mais rapidamente que as forças intermitentes. A quantidade de movimentação obtida encontrase na proporção aproximada de $1 \mathrm{~mm} / \mathrm{mês}$, embora haja uma grande variação individual. Vale salientar que essa movimentação se dá mais pela inclinação para distal da coroa do que pelo movimento de corpo do molar, pois com a movimentação dos molares, a inclinação axial dos dentes se 
altera, com as coroas movendo-se mais distalmente do que as raízes. Se os molares forem movimentados de corpo ao longo de um fio rígido, sua proporção de movimentação diminui para $0,5 \mathrm{~mm} / \mathrm{mês}$. Isso sugere que um fator que influi na proporção da distalização é o tipo de movimentação. $O$ movimento mais rápido ocorre quando o molar é inclinado para distal. Contudo, se os segundos molares não se apresentarem irrompidos, a proporção aumenta para mais de $1 \mathrm{~mm} /$ mês. $^{56}$

A distalização deve prosseguir até que os molares atinjam uma sobrecorreção de aproximadamente $2 \mathrm{~mm}^{56}$. A sobrecorreção é necessária por duas razões principais:

- a perda de ancoragem invariavelmente ocorre durante a retração dos pré-molares, caninos e incisivos e a sobrecorreção serve para compensar essa perda de ancoragem. Em outras palavras, a sobrecorreção constitui-se num "preparo de ancoragem",56

- os molares distalizados geralmente se movimentam pela inclinação para distal, com a movimentação maior da coroa do que da raiz. Após a sobrecorreção, o movimento para anterior subseqüente dos molares leva a uma verticalização das raízes, movimentando as coroas mais para mesial do que as raízes. ${ }^{56}$

Os molares distalizados possuem alta tendência de recidivar para mesial, particularmente se os segundos molares estiverem presentes. Essa tendência foi documentada por ANDREASEN; NAESSIG ${ }^{6}$ ao notarem que $90 \%$ da distalização do molar produzida pelo AEB foi perdida em uma semana, após a remoção do AEB, sem o uso de qualquer tipo de contenção. O autor recomendou, para a manutenção da posição do molar, o uso de aparelhos de contenção, como, por exemplo, o AEB de uso noturno.

Além disso, os molares não devem ser utilizados como ancoragem por pelo menos 4 a 5 meses após sua distalização, pois a perda de ancoragem pode ocorrer prontamente mesmo com o uso do $A E B^{56}$. Isso reflete a natureza instável dos molares imediatamente após a sua 
distalização. Recomenda-se, por isso, que a mecânica de retração seja iniciada somente 4 a 5 meses pós-distalização. Contudo, isso não se torna uma inconveniência, porque os pré-molares e caninos distalizam por si próprios durante esse período de tempo. ${ }^{10}$

Os terceiros molares superiores irrompidos ou semi-irrompidos tendem a impedir a distalização dos primeiros e segundos molares. Por esta razão, quando possível, indica-se a extração desses dentes ${ }^{56}$.

Segundo GIANELLY ${ }^{56}$, o prognóstico e o índice de sucesso dessa terapêutica dependem da faixa etária apresentada pelos pacientes, que podem então ser divididos em três grupos:

- GRUPO 1: quando os primeiros molares são distalizados na dentadura mista tardia, o procedimento apresenta $90 \%$ ou mais de sucesso. E a correção do molar se dá dentro de 4 a 8 meses.

- GRUPO 2: na adolescência, quando os primeiros molares distalizam após a irrupção dos segundos molares superiores, eles tendem a se mover mais lentamente e a perda de ancoragem aumenta. A relação molar de $1 / 2$ Classe II é corrigida razoavelmente bem. A relação de Classe II completa torna-se mais difícil de resolver. Em muitos momentos, o tratamento alcança o sucesso embora se recomende que haja controle da ancoragem dos incisivos superiores, com o uso de elásticos de Classe Il quando o aumento do trespasse horizontal exceder $2 \mathrm{~mm}$.

- GRUPO 3: no adulto, o sucesso é altamente variável e observam-se muitas dificuldades.

Deve-se atentar para a grande variação individual observada, indicando que a capacidade de distalizar os molares superiores ainda não permite um prognóstico confiável e totalmente previsível.

Para a realização do tratamento distalizador, várias formas de tratamento foram idealizadas. Inicialmente, foram sugeridos aparelhos que dependiam da colaboração dos pacientes como os aparelhos extrabucais, aparelhos removíveis com molas digitais, arco de Wilson, dentre outros. 


\section{4 - DISTALIZADORES DEPENDENTES DA COOPERAÇÃO DO PACIENTE}

\subsection{1 - APARELHO EXTRABUCAL (AEB)}

Norman William KINGSLEY ${ }^{79 A}$ descreveu, pela primeira vez, em 1875, o aparelho extrabucal para a correção da Classe II. Porém, somente por volta de $1940, \mathrm{KLOEHN}^{82}$ introduziu o aparelho extrabucal com tração cervical, fato que proporcionou a sua ampla utilização na Ortodontia. Desde então, vários efeitos ortopédicos foram observados no decorrer do tempo, principalmente a restrição do crescimento anterior da maxila, favorável para a correção da Classe II esquelética. Além dos efeitos ortopédicos, havia também as alterações ortodônticas, representadas, essencialmente, pela distalização dos molares superiores, que foi prontamente utilizada na terapia ortodôntica.

Assim, o primeiro aparelho utilizado com a finalidade de distalizar os molares superiores para a correção da relação molar de Classe Il consistiu no aparelho extrabucal (AEB). Desde os primeiros estudos sobre os seus efeitos no complexo craniofacial, a distalização dos molares superiores sempre foi uma constante. KLEIN ${ }^{81}$, em 1957, investigou as alterações ocorridas nos primeiros molares superiores e no padrão de crescimento de pacientes submetidos ao aparelho extrabucal, tração cervical. Pacientes com idade média de 8 anos e 6 meses, todos com Classe II divisão 1 , foram submetidos ao uso do AEB, tração cervical, por um período médio de 17 meses. A remoção do aparelho se deu a partir da correção da relação molar. Telerradiografias inicial e final foram requeridas para a análise cefalométrica. Os resultados mostraram que: o crescimento mandibular médio representado pela distância S-Gn foi de $4 \mathrm{~mm}$; o ângulo entre o eixo y e o plano de Bolton abriu $1^{\circ}$, o que significa que a mandíbula sofreu uma rotação para trás e para baixo; diminuição da convexidade facial em 2,8; retração maxilar de 1,3; aumento da angulação do plano palatino 
para baixo e anteriormente em 1,75우 alterações muito suaves no plano oclusal; inclinação para distal do segundo molar superior de 1,2º; movimento para distal do primeiro molar superior de $1 \mathrm{~mm}$ e extrusão do mesmo de 2,3mm. O autor concluiu que: 1) o grau e a direção da inclinação dos molares superiores podem ser controlados pela manipulação do aparelho; 2) observourse movimento distal de corpo na maioria dos casos; 3) a extrusão não aconteceu num grau considerado lesivo ao tratamento; 4) o ponto A se moveu para trás (SNA diminui significantemente). Adicionado a isso, o autor afirmou que há três formas de se corrigir a Classe II em pacientes em crescimento, por meio do uso do AEB cervical: 1) distalização dos molares superiores; 2) manutenção da posição dos molares superiores em relação à maxila, enquanto os molares inferiores continuam o seu movimento natural para anterior; e 3) redirecionamento do crescimento anterior da maxila.

Os efeitos decorrentes do tratamento com o AEB dependem da direção em que se emprega a força. Existem três tipos de tração maxilar, variando a direção da força: alta, média e cervical ou baixa.

Com o intuito de avaliar as alterações provocadas pelos aparelhos extrabucais, de tração cervical (KHG) e de tração alta (IHG) e pelo ativador (aparelho ortopédico funcional), comparadas com um grupo controle, BAUMRIND et al. $^{14}$, em 1983, analisaram 238 pacientes apresentando Classe II, divisão 1, sendo 50 pertencentes ao grupo controle e o restante submetido a um dos tratamentos citados. As alterações foram avaliadas em telerradiografias em norma lateral inicial, intermediária e final. Os resultados obtidos mostraram que o crescimento e desenvolvimento normal esperado (analisado no grupo controle) leva a um deslocamento para baixo e para frente da maxila, bem como a uma movimentação para anterior e para baixo dos molares superiores. Nos pacientes tratados com a tração cervical, observou-se a redução no deslocamento anterior da maxila, além da ausência da movimentação ântero-posterior dos molares superiores, porém com componente extrusivo. Já na tração alta, tanto os efeitos ortopédicos quanto os ortodônticos apresentaram-se maiores em 
comparação aos demais. Houve uma grande redução da tendência de movimentação para frente e para baixo da maxila adicionada à significativa distalização dos molares superiores, maior inclinação da coroa para distal e intrusão relativa. Os efeitos do ativador constituíram-se bem suaves, comparativamente. Tanto ortodonticamente quanto ortopedicamente, observaram-se no grupo tratado com o ativador as mesmas peculiaridades do grupo controle, contudo em menor magnitude. Parece que o maior efeito do ativador seria mesmo mandibular.

Já O'REILLY; NANDA; CLOSE ${ }^{100}$, em 1993, compararam os efeitos dos $A E B s$ de tração baixa e média durante o tratamento ortodôntico fixo, na fase da puberdade. Quarenta pacientes foram analisados, sendo 20 submetidos à tração cervical e os 20 restantes à tração média. Todos os pacientes apresentavam Classe II, divisão 1, com idade média de 12,7 anos para os meninos e 10,6 anos para as meninas. Os pacientes se encontravam numa fase similar de crescimento, que foi avaliada pela radiografia de mão e punho, que demonstrou se apresentarem no período prévio ao pico de crescimento puberal. Na avaliação inicial, constatourse que os pacientes possuíam padrão esquelético para mordida aberta, ou seja, plano oclusal inclinado no sentido anti-horário e retrusão mandibular de 5 a $7 \mathrm{~mm}$. Os AEBs de tração baixa ou cervical tiveram o seu arco externo angulado em $30^{\circ}$ em relação ao interno. Recomendoutse a utilização dos aparelhos por $14 \mathrm{~h} / \mathrm{dia}$. O crescimento normal do plano palatino em pacientes com padrão esquelético de mordida aberta obedece a uma rotação antihorária. Com a utilização do AEB de tração cervical, a espinha nasal anterior deslocou-se mais inferiormente do que o normal. A espinha nasal posterior movimentou-se inferiormente durante o tratamento com o AEB de tração cervical e, superiormente, com o AEB de tração média. $O$ crescimento maxilar anterior foi minimizado em ambos. Os primeiros molares superiores sofreram um deslocamento inferior com 0 uso do AEB cervical e permaneceram estáticos, verticalmente, no tratamento com a tração média. No sentido ântero-posterior, não houve diferença estatisticamente 
significante. Ambos inibiram ou minimizaram o aumento do comprimento do palato, porém somente após a terapia com o AEB cervical constatou-se aumento da altura palatina. Os autores concluíram que, para os pacientes com mordida aberta esquelética e nos quais o mento apresentava-se retruído em relação à face superior, o AEB cervical contribuiu para o aumento da altura facial ântero-inferior. Nesses pacientes, estaria mais indicado o uso do AEB de tração média ou alta.

Devido às variações na forma de ação dos aparelhos extrabucais em decorrência das diferentes direções da força empregada, a indicação tem como fator principal o padrão de crescimento do paciente. Como afirmado por O'REILLY; NANDA; CLOSE $^{100}$, em pacientes com tendência ao crescimento vertical contra-indica-se o AEB cervical, pois a mandíbula sofreria uma rotação em sentido horário, com um conseqüente aumento da altura facial ântero-inferior (AFAl), muito desfavorável à estética do paciente. Devido a isso, indica-se nesses casos a tração alta. Já para os pacientes com tendência para o crescimento horizontal, O AEB cervical estaria bem indicado, pois com a extrusão dos molares superiores, ocorre o aumento da AFAl, não comprometendo a estética facial do paciente. E, como visto nos trabalhos anteriores, independente da direção da força extrabucal, há sempre o componente posterior da força, o que possibilita a distalização dos molares superiores em quaisquer das variações do aparelho.

O tratamento precoce da Classe II, divisão 1, por meio do uso do $A E B$, na dentadura mista, encontra-se bastante reportado na literatura. ${ }^{40}$, 98. Os benefícios da atuação precoce constituem-se na possibilidade da correção das discrepâncias esqueléticas, melhor colaboração do paciente e simplificação do tratamento ortodôntico fixo. ${ }^{40}$ Primeiramente, instalou-se o AEB de tração alta, com uso por $14{ }^{98}$ a $16 \mathrm{~h} /$ dia ${ }^{40}$, mantido até a correção da relação molar. A duração dessa fase compreendeu 15 meses em média ${ }^{40}$. Em seguida, o aparelho ortodôntico fixo foi instalado para o alinhamento e nivelamento dos arcos dentários e o AEB passou a ser utilizado somente à 
noite. Os resultados obtidos revelaram que a protrusão maxilar diminuiu pela combinação da restrição do crescimento maxilar e pelo significativo crescimento mandibular; houve distalização dos molares superiores e retração dos incisivos superiores, conseqüentemente proporcionando melhora do perfil facial ${ }^{40,98}$. Os exames clínico e radiográfico revelaram estabilidade desses resultados após dois anos da finalização do tratamento ${ }^{98}$.

Com o intuito de determinar os efeitos cefalométricos da terapia Edgewise sem extração associada ao uso do aparelho extrabucal de tração cervical, CANGIALOSI et al..$^{32}$, em 1988, avaliaram 43 pacientes, com idade média de 11 anos e 11 meses. Todos possuíam relação molar de Classe II completa, ANB médio de 4,9ำ e foram tratados por um tempo médio de 2 anos e 8 meses. Foram utilizados elásticos de Classe II para a finalização do tratamento durante 2 a 5 meses. Os resultados demonstraram uma diminuição do SNA, devido a uma restrição do crescimento maxilar; um aumento mínimo do SNB, porém não significante estatisticamente; conseqüentemente, conduzindo a uma redução significativa do ANB de 1,620; inclinação anti-horária do plano palatino, com aumento da altura facial superior; inclinação lingual dos incisivos superiores; redução da convexidade facial; extrusão dos primeiros molares de $2,77 \mathrm{~mm}$ e mesialização de $1,06 \mathrm{~mm}$, contrariamente a estudos anteriores. Ocorreu uma extrusão similar de $3,08 \mathrm{~mm}$ e mesialização de $0,81 \mathrm{~mm}$ dos molares inferiores. Os autores afirmaram que, por se tratar de um estudo retrospectivo, não houve controle da cooperação dos pacientes e da duração e intensidade da força empregada pelo aparelho extrabucal. Contudo, concluíram que, apesar dos efeitos adversos, há uma eficácia no tratamento da Classe II, divisão 1 por meio do uso do aparelho extrabucal de tração cervical.

A estabilidade da correção da Classe II tratada por meio do AEB foi avaliada por ELMS; BUSCHANG; ALEXANDER ${ }^{42}$, em 1996. A amostra analisada constituía-se de pacientes leucodermas, entre 7 e 14 anos, apresentando Classe II, divisão 1, tratados pelo mesmo ortodontista 
com o AEB cervical, com $459 \mathrm{~g}$ de força, utilizado de 12 a 16h/dia por pelo menos 8 meses. A duração do tratamento compreendeu 3 anos em média, já com os dentes alinhados e nivelados pelo aparelho ortodôntico fixo. A contenção durou 2,5 anos e os pacientes foram avaliados ainda num período de 6,5 anos após a remoção do aparelho ortodôntico fixo. $\mathrm{Na}$ análise cefalométrica, constatourse a correção do ANB pela diminuição do ângulo SNA, o que reflete que a maxila permaneceu estável ou foi levemente deslocada para posterior. Os molares superiores demonstraram extrusão e distalização suficientes para a correção da relação molar. A mandíbula cresceu consideravelmente, sem demonstrar rotação aparente durante 0 tratamento. As alterações pós-tratamento demonstraram a estabilidade da correção.

Em outro estudo, ELMS; BUSCHANG;ALEXANDER ${ }^{41}$, também em 1996, avaliaram, em modelos, os efeitos transversais do AEB cervical associado ao aparelho ortodôntico fixo, utilizando a mesma amostra do estudo anterior. Foi analisada também a estabilidade dos casos. A maior parte das alterações transversais apresentaram-se pequenas e, provavelmente, refletem as modificações fisiológicas esperadas. A recidiva, apesar de limitada, ocorreu em alguns pacientes em que houve sobreexpansão durante o tratamento. Verificou-se que, no tratamento sem extrações da Classe II, divisão 1, a expansão dos molares constituiurse mais estável que a dos caninos. O relacionamento entre os incisivos superiores e os inferiores permaneceu muito satisfatório e os autores afirmaram que a estabilidade não depende da quantidade da alteração realizada pelo tratamento mas, sim da qualidade dos trespasses horizontal e vertical obtidos no final do tratamento. O apinhamento ântero-inferior recidivou, porém em $90 \%$ da amostra esse não atingiu 3,5mm, permanecendo em níveis muito satisfatórios clinicamente. Os autores concluíram que a terapia sem extrações aplicada para a Classe II, divisão 1, dentro dos parâmetros deste estudo, apresentou-se estável em sua maioria. A recidiva limitou-se a poucas medidas e parece restringir-se àqueles pacientes em que houve uma 
quantidade de alterações excessivas causadas durante o tratamento. A recidiva real atingiu, em alguns casos, níveis inferiores a $20 \%$ da movimentação realizada. A correção da Classe II, divisão 1, por meio do uso do AEB cervical foi considerada estável, desde que um diagnóstico e tratamento adequados sejam realizados em pacientes cooperadores, possuindo um padrão de crescimento favorável.

Além das alterações ortopédicas já descritas, KIRJAVAINEN; KIRJAVAINEN; HAAVIKKO ${ }^{80}$, em 1997, analisaram os efeitos transversais nos arcos dentários do AEB cervical com o arco interno aberto em $10 \mathrm{~mm}$ e o externo angulado superiormente em 15․ $O$ tratamento baseou-se exclusivamente no uso do AEB cervical, instalado pelo mesmo operador, com força de $500 \mathrm{~g} / \mathrm{lado}$ por $12 \mathrm{a} 14 \mathrm{~h} / \mathrm{dia}$. A média de idade dos meninos foi de 9,8 anos ( $d p=1,2$ anos) e das meninas, 8,9 anos ( $d p=1,2$ anos). Após um tempo médio de tratamento de 1,8 anos, obteve-se a relação de Classe I. Tanto o arco dentário superior como o inferior sofreram uma expansão significativa. $O$ incremento anual da distância intercaninos e intermolares apresentourse significantemente maior comparado a um grupo controle, com exceção da distância intercaninos inferiores nos meninos. O comprimento do arco dentário superior aumentou significantemente, não ocorrendo alterações consistentes no inferior. A expansão maxilar foi seguida espontaneamente pela expansão e desinclinação do arco dentário inferior.

Procurando avaliar a estabilidade da correção da Classe II tratada com o AEB de tração cervical, LIMA; LIMA ${ }^{85}$, em 2000, apresentaram um caso clínico estável após 16 anos da finalização do tratamento. Inicialmente, a paciente possuía um padrão esquelético de Classe I (ANB = 2,5\%), Classe II, divisão 1 dentária e 12 anos de idade. Adotou-se uma mecânica sem extração por meio da expansão maxilar e distalização dos molares superiores por meio de um AEB cervical, com força leve de 200 a $250 \mathrm{~g} /$ lado e uso de 12 a 14h/dia, por um período de 12 meses. O tratamento durou 24 meses em média. O perfil da paciente não se alterou; portanto, a terapia ortodôntica não trouxe efeitos adversos à estética facial da paciente. 
Os efeitos do AEB, em sua maioria, ocorreram apenas em nível dentoalveolar. Decorridos 16 anos do tratamento, a expansão maxilar, o alinhamento dentário e a relação de Classe I mantiveram-se estáveis. Houve permanência do perfil agradável da paciente com o crescimento do nariz e do mento. As alturas faciais anterior e posterior aumentaram significantemente.

\subsubsection{1 - Efeitos adversos promovidos pelo AEB:}

Apesar dos sucessos observados na literatura da terapia da Classe II com o AEB, há alguns relatos isolados de efeitos colaterais decorrentes dessa mecânica. LANGFORD; SIMS ${ }^{84}$, em 1981, apresentaram um caso clínico de uma paciente, com 10 anos de idade, Classe II, divisão 1, submetida ao tratamento distalizador dos molares superiores. Com o uso do AEB cervical por 5 1/2 meses, obteve-se a relação molar de Classe I. Contudo, decorridos 19 meses da distalização, verificou-se uma grande reabsorção radicular dos primeiros molares superiores, o que levou à sua extração em substituição da extração anteriormente planejada dos primeiros pré-molares. Os primeiros molares superiores foram extraídos e observados em microscopia eletrônica. Amplas áreas da superfície radicular demonstravam lacunas de Hawship, porém algumas em reparo e outras já reparadas. Contudo, não há evidências de que o ligamento periodontal se insere nesse tecido de reparo, pois as fibras de Sharpey não foram visualizadas. Além disso, a raiz distovestibular do primeiro molar esquerdo foi reabsorvida completamente. Segundo os autores, isso ocorreu provavelmente devido à movimentação e/ou o padrão de irrupção do segundo molar adjacente, que se encontrava em erupção ectópica. Concluíram que a reabsorção radicular verificada reduziu significantemente a área de inserção periodontal; a distalização dos primeiros molares superiores contra dentes não irrompidos pode causar reabsorção; e que o padrão de erupção dos segundos molares pode ser responsável parcial ou totalmente pela reabsorção das raízes dos primeiros molares. Os autores 
reforçam a necessidade de cautela na movimentação radicular contra coroas de dentes não irrompidos, desde que a reabsorção radicular representa uma conseqüência possível desse tratamento.

\subsection{2 - APARELHO REMOVÍVEL DISTALIZADOR (ACCO) ASSOCIADO AO USO DO AEB}

A utilização da força extrabucal combinada aos aparelhos removíveis para o tratamento da Classe II esquelética data de muitos anos na literatura por meio dos aparelhos ortopédicos funcionais. A combinação dos aparelhos extra e intrabucais para corrigir algumas más oclusões demonstrou ser superior ao uso exclusivo do aparelho intra ou extrabucal. ${ }^{61}$ BERNSTEIN ${ }^{15}$, em 1970, e CETLIN; TEN HOEVE ${ }^{35}$, em 1983, defenderam uma técnica sem extrações, utilizando um aparelho removível associado ao AEB na primeira fase do tratamento, para correção da Classe II dentária e esquelética. $O$ protocolo proposto por CETLIN; TEN HOEVE ${ }^{35}$ corrige a relação molar com o uso de uma placa distalizadora conjuntamente ao aparelho extrabucal. A direção da força varia de acordo com o tipo facial do paciente. Para controlar a posição vertical dos primeiros molares superiores, o arco externo deve ser angulado até que coincida com o centro de resistência do molar. $O$ aparelho extrabucal deve ser utilizado de 10 a $12 \mathrm{~h} /$ dia e produzir uma força de 150 a $200 \mathrm{~g} / \mathrm{lado}$ ou mais, se um efeito ortopédico na maxila for desejado. No arco dentário inferior, uma placa lábioativa elimina a pressão muscular dos lábios e bochechas, promovendo expansão funcional e abertura da mordida. A melhor época para iniciar o tratamento compreende a da dentadura mista tardia; pois a esfoliação dos segundos molares decíduos superiores facilita a inserção da placa. $\mathrm{Na}$ presença de musculatura peribucal anormal ou apinhamento inferior severo, recomenda-se que a placa lábio-ativa seja instalada na dentadura mista precoce. 
O aparelho removível utilizado constitui-se numa modificação da placa de Hawley ${ }^{15}$. O aparelho é comumente referido como ACCO appliance ( $A C$ de acrylic resin; CO para cervico-occipital). $O$ aparelho consiste de uma unidade de ancoragem e uma unidade de trabalho. A unidade de ancoragem compreende um arco vestibular com resina acrílica por vestibular dos incisivos superiores, com a finalidade de retenção. Grampos de Adams nos primeiros pré-molares conferem retenção e estabilidade ao aparelho. A unidade de trabalho consiste em duas molas digitais confeccionadas com fio de aço inoxidável, calibre 0.028 ", com helicóides de $5 \mathrm{~mm}$ de diâmetro e uma extensão interproximal que alcança a superfície mesiovestibular do primeiro molar superior, já devidamente bandado. Essa extensão interproximal deve se localizar no nível gengival para minimizar a inclinação da coroa. Essas molas são ativadas 3 a $4 \mathrm{~mm}$, para aplicar uma força para distal de aproximadamente 100 a 150g, sendo reativadas mensalmente. Um plano incisal deve ser confeccionado na face palatina dos incisivos superiores para desocluir levemente os dentes posteriores, promovendo uma distalização facilitada dos molares superiores.

A movimentação esperada com o uso somente do aparelho ACCO constitui-se na inclinação da coroa do molar para distal, já que o ponto de aplicação da força por meio da mola digital se localiza oclusalmente ao centro de resistência do molar, inclinando a coroa distalmente no sentido horário e deixando as raízes em sua posição original. Por essa razão, indica-se a utilização de um AEB cervical com o arco externo angulado, de forma a produzir uma linha de força sobre o centro de resistência do molar, criando um momento distal sobre as raízes dos molares, resultando na verticalização das raízes em relação às coroas inclinadas. $O$ efeito resultante é a movimentação de corpo para distal do molar. Recomenda-se o uso do aparelho ACCO durante 24h/dia e o AEB de tração cervical, por 12 a $14 \mathrm{~h} /$ dia. $^{75}$

A seleção do paciente é um procedimento muito importante, pois o aparelho ACCO não possui indicação universal. Uma avaliação clínica 
e radiográfica deve fornecer dados para o dignóstico da má oclusão e plano de tratamento. Embora empregado no tratamento das más oclusões esqueléticas e dentárias, o aparelho ACCO apresenta-se mais indicado para pacientes em crescimento e adultos que possuem uma relação esquelética facial aceitável, boa forma do arco dentário inferior, padrão de crescimento favorável (horizontal), sobremordida normal a profunda e má oclusão de Classe II dentária com perda do perímetro do arco superior. ${ }^{75}$

Apesar do aparelho ACCO associado ao AEB cervical possuir muitas aplicações, está contra-indicado em pacientes com mordida aberta e padrão facial desfavorável (vertical), porque há tendência da mordida abrir quando os molares superiores distalizam. Se o paciente com características verticais for tratado com o aparelho ACCO, indica-se o AEB de tração alta, em substituição ao AEB de tração cervical. ${ }^{75}$

Com o objetivo de avaliar o método proposto por CETLIN; TEN $\mathrm{HOEVE}^{35}$, vários autores analisaram pacientes submetidos a esse tratamento. ${ }^{53,75}$

JOHNSON $^{75}$, em 1994, reportou o tratamento de uma paciente adulta, na qual se utilizou o AEB cervical combinado ao aparelho ACCO na primeira fase da terapia, atentando para a recuperação de espaço no arco superior e a correção da Classe II, seguida pela instalação do aparelho ortodôntico fixo para o detalhamento da oclusão. Inicialmente, a relação molar apresentava-se topo-a-topo e havia uma tendência de Classe II, porém a relação esquelética era normal entre as bases ósseas apicais. Após 5 meses de uso do aparelho ACCO associado ao AEB cervical, obteve-se espaço adequado para acomodação de todos os dentes superiores. $\mathrm{O}$ aparelho ortodôntico fixo foi instalado com a suspensão do uso do aparelho ACCO e permanência do AEB cervical para manter o espaço obtido. $O$ tempo de tratamento compreendeu 18 meses. A cooperação da paciente constituiu em fator essencial para o sucesso do tratamento. $O$ autor concluiu que o ACCO associado ao AEB de tração cervical, movimenta os molares 
para distal de corpo em vez da inclinação que a maioria dos aparelhos removíveis produz. Pode ser utilizado bilateral ou unilateralmente.

Em 2000, GIANCOTT ${ }^{3}$ apresentou o caso de um paciente com 10 anos, na dentadura mista, Classe II completa, possuindo $10 \mathrm{~mm}$ de trespasse horizontal e padrão de crescimento vertical, tratado segundo 0 protocolo sugerido por CETLIN, TEN HOEVE ${ }^{35}$. A placa removível com molas digitais (ACCO) foi utilizada por 24h/dia, liberando uma força aproximada de 30 a $40 \mathrm{~g}$. Devido ao padrão de crescimento vertical, o paciente usou o AEB de tração alta por 14 a 16h/dia. Em função da ótima colaboração do paciente, obteve-se a relação de Classe I em 6 meses. A manutenção da Classe I se deu com o uso do AEB de tração alta, por 10 a 14h/dia. No arco dentário inferior, utilizou-se uma placa lábio-ativa para manter o "Leeway Space". O tempo médio do tratamento compreendeu 30 meses. O sucesso alcançado deveu-se principalmente à alta colaboração do paciente, apesar do padrão de crescimento desfavorável e a Classe II de natureza esquelética.

As alterações dentoesqueléticas produzidas pela terapia preconizada por CETLIN; TEN HOEVE ${ }^{35}$ foram avaliadas, em 2000, por FERRO; MONSURRÓ; PERILLO ${ }^{45}$. A amostra consistia de 110 pacientes, todos Classe II,divisão 1 , com idade média de 10 anos no início do tratamento e 11 anos ao final. Os pacientes apresentavam pelo menos $1 / 2$ Classe II dentária e, esqueleticamente, 51 deles possuíam padrão de Classe I (ANB $=2^{\circ}, \mathrm{dp}=2^{\circ}$ ) e 59 tinham Classe II esquelética (ANB $>4^{\circ}$ ). Desses, 50 constituíam-se em pacientes braquifaciais, 57 mesofaciais e somente 3 possuíam características dolicofaciais. Os dados foram comparados a um grupo controle apresentando Classe II, divisão 1, de mesma idade cronológica, não tratado. Os resultados revelaram que a correção da relação molar ocorreu mais às expensas da distalização dos molares superiores nos pacientes braquifaciais; houve inclinação distal dos molares superiores em $70 \%$ da amostra, movimento de corpo em 9\% e inclinação mesial em $21 \%$ (talvez em decorrência do uso demasiado do AEB); o ponto A distalizou em 
$44 \%$ dos casos e o ponto B não se alterou significantemente; a placa lábioativa promoveu suave distalização dos molares inferiores, com inclinação distal das coroas. O principal efeito colateral desta terapia constituiurse na grande perda de ancoragem ântero-superior verificada pela vestibularização e protrusão dos incisivos superiores em $81 \%$ da amostra. Essa deveurse ao uso insuficiente do $A E B$ e/ou à não-utilização dos elásticos de Classe II durante a distalização dos molares superiores. Os autores afirmaram que os diferentes efeitos obtidos ocorreram principalmente em decorrência da grande variação na colaboração no uso do AEB.

\subsection{3 - ARCO DE WILSON:}

A utilização inicial do arco proposto por WILSON ${ }^{127}$, WILSON; WILSON ${ }^{128,} 129$ foi relatada por MUSE et al. ${ }^{97}$, em 1993. O aparelho caracteriza-se pela presença de um arco de distalização bimétrico superior adaptado passivamente ao aparelho ortodôntico fxo convencional. $\mathrm{O}$ arco distalizador possui uma secção anterior confeccionada com fio de aço inoxidável de 0.020 " e outra posterior, com fio 0.045 " que se insere no tubo molar do AEB. A mola aberta de 0.045 " x 0.010", com comprimento de $5 \mathrm{~mm}$, encontra-se entre o tubo molar e um ômega inserido no arco acima descrito, por anterior. Há um stop por mesial do ômega. A ativação inicial se dá pelo fechamento do ômega, de maneira a comprimir a mola e estacionar o stop no arco. As ativações seguintes são feitas pela abertura do ômega, comprimindo a mola aberta. Incorpora-se um gancho na altura dos caninos para o uso integral de elásticos de Classe II. No arco dentário inferior, WILSON $^{127}$, WILSON; WILSON ${ }^{128,}{ }^{129}$ recomendaram o uso de um arco lingual para ancoragem, diminuindo o efeito protrusivo decorrente dos elásticos de Classe II. A amostra constituiurse de 19 pacientes com idade média de 13 anos, possuindo Classe II dentária bilateral. Após a ativação inicial de 3mm da mola aberta, indicou-se o uso de elásticos de Classe II de 1/4" por 23h/dia. As reativações da mola foram mensais. A correção da relação molar se deu em 16 semanas ou menos nos pacientes 
colaboradores. O primeiro molar superior inclinou para distal em todos os casos, em média $7,8^{\circ}$. Quanto maior a distalização, maior a inclinação observada. Devido a essa inclinação, a estabilidade dos casos tornourse questionável. Uma significante proporção da correção da Classe II ocorreu pela mesialização do primeiro molar inferior, sendo quantificada em $39,8 \%$ da correção $(1,38 \mathrm{~mm})$ e 50,7\% em decorrência da distalização dos molares superiores $(2,16 \mathrm{~mm})$. A presença ou não do segundo molar superior irrompido não influenciou na distalização obtida. A proporção de distalização compreendeu $0,56 \mathrm{~mm} / \mathrm{mês}$. A quantidade de distalização correlacionoutse com a posição dos incisivos e ao uso dos elásticos de Classe II, ou seja, quanto maior a cooperação, tanto maior a distalização.

HARNICK $^{66}$, em 1998, reportou o tratamento de uma paciente por meio da distalização dos molares superiores com o arco de Wilson. Devido à idade da paciente (13 anos e 4 meses, em fase pós-menarca), optou-se pela extração dos segundos molares superiores, o que facilitaria a distalização dos primeiros molares. A paciente apresentava Classe II completa, de natureza esquelética (ANB $=10^{\circ}$ e Witts $=10 \mathrm{~mm}$ ). A terapia com 0 arco de Wilson foi realizada convencionalmente com 0 uso de elásticos de Classe II integrais, ancorados pelo arco dentário inferior com fio retangular. $O$ tratamento finalizourse com sucesso num período de 22 meses, com melhora do perfil facial, oclusão em relação molar e canino normais, selamento labial e primeiros molares superiores verticalizados. Os molares superiores distalizaram aproximadamente $4 \mathrm{~mm}$, sem extruir significantemente. O ponto A moveu-se distal e inferiormente, em conseqüência do movimento para distal dos incisivos superiores e a AFAI aumentou em $3 \mathrm{~mm}$. O autor concluiu que, quando bem indicado, atentando para os detalhes que surgem durante 0 tratamento, o arco de Wilson demonstra ótima eficiência na correção da Classe II dentária e esquelética. 


\subsection{4 - Outros distalizadores dependentes da cooperação do paciente:}

Outras formas de distalização baseadas na cooperação dos pacientes surgiram na literatura. RITTO ${ }^{112}$, em 1995, propôs a utilização de uma placa confeccionada com "Biocryl" em máquina a vácuo. A placa estende-se de segundo pré-molar a segundo pré-molar superior, possuindo 2 grampos internos para retenção e uma mola de secção aberta de níqueltitânio em uma extensão de fio de aço inoxidável entre a placa e o tubo do molar, de maneira a distalizar os molares superiores com força aproximada de $220 \mathrm{~g}$. As molas eram reativadas, quando necessário. Uma das maiores vantagens desse aparelho compreende a desoclusão dos dentes posteriores de 1 a $2 \mathrm{~mm}$, facilitando a distalização dos molares superiores. Os molares inicialmente distalizaram aproximadamente 1,5 a $2 \mathrm{~mm}$. A inclinação dos molares observada questiona a estabilidade da movimentação. Devido a isso, a melhor indicação para esse sistema compreende os casos em que os molares superiores encontram-se inclinados para mesial. Deve-se esperar melhor colaboração do paciente no uso desse aparelho, pois esse possui um tamanho bem menor comparado aos aparelhos removíveis convencionais, é mais confortável e estético.

Já, GHOSH; NANDA ${ }^{51}$, em 1996, apresentaram uma terapia distalizadora baseada no uso integral do AEB combinado a um arco segmentado de aço 0.016 " entre o primeiro molar e o segundo pré-molar, em que uma mola aberta de níquel-titânio produzia uma força para distal de 150g. A ancoragem consistia em um botão de Nance ligado às bandas dos segundos pré-molares superiores. Uma paciente, em fase pré-menarca, com 11 anos e 1 mês, $1 / 2$ Classe II, protrusão acentuada dos incisivos superiores e sobremordida bem profunda, submeteurse a essa terapia. Uma Classe I sobrecorrigida foi obtida decorridos 4 meses. Houve perda de ancoragem representada pela mesialização dos segundos pré-molares de $2 \mathrm{~mm}$. Em seguida, os segundos e os primeiros pré-molares foram distalizados com o apoio da ancoragem do AEB. A paciente mostrourse muito cooperadora e o tratamento finalizourse após 36 meses. Os autores consideraram fatores 
importantes para o sucesso da terapia a presença de crescimento favorável, o estágio de irrupção dos segundos molares superiores e a cooperação da paciente.

Outra alternativa para a distalização dos molares superiores foi sugerida por SEGURA; FULL ${ }^{119}$, em 1997, por meio da fabricação de um cursor a partir da confecção de dois pequenos helicóides nos extremos entre o primeiro molar/segundo pré-molar superiores e canino/incisivo lateral superiores em um fio de aço inoxidável de calibre 0.028 ", para a posterior inserção no arco principal superior. Um gancho na região do canino estabelece o uso de elásticos de Classe II. As principais indicações consistem: distalização unilateral, bom posicionamento maxilar e falta de cooperação do paciente no uso do AEB. Uma paciente do gênero feminino utilizou o método proposto. A queixa principal consistia nos caninos superiores apinhados e vestibularizados, em decorrência de uma deficiência de espaço superior de $8 \mathrm{~mm}$. Ao exame clínico, a paciente apresentava uma Classe II dentária e cefalometricamente revelou uma Classe I esquelética. A discrepância de modelo inferior era de $2 \mathrm{~mm}$. $\mathrm{O}$ aparelho ortodôntico fixo foi instalado. Com um fio 0.028" de aço inoxidável, confeccionourse o sistema distalizador associado ao uso de elásticos de Classe II em período integral, por 6 semanas. Após esse período, houve correção da relação molar e espaço para o alinhamento e nivelamento de todos os dentes. A principal vantagem desse aparelho representa a possibilidade da sua confecção pelo próprio ortodontista durante a consulta sem grande consumo de tempo. Contudo, a cooperação é fundamental. 


\section{5 - A COOPERAÇÃO EM ORTODONTIA}

O sucesso dos tratamentos distalizadores descritos anteriormente requerem a cooperação dos pacientes. A decisão para a procura por tratamento ortodôntico freqüentemente parte dos pais ${ }^{38,39} \mathrm{e}$ devido a isso, muitas vezes o paciente pode não estar disposto a cooperar.

Os ortodontistas, em geral, atentam para o desenvolvimento de critérios acessíveis para a identificação de pacientes colaboradores. BROEKMAN $^{27}$ cita maior cooperação pelas meninas, especialmente acima dos 14 anos de idade. Entretanto, muitos estudos indicam que a melhor cooperação correlaciona-se aos pacientes pré-adolescentes. ${ }^{1,83}$ Porém, Mc DONALD ${ }^{94}$ não encontrou relação entre idade e índice de colaboração dos pacientes.

Inversamente, a cooperação dos pacientes relaciona-se à sua colaboração na escola. KREIT; BURSTONE; DELMAN ${ }^{83}$, em 1979, administraram um questionário a 1386 pacientes, sendo que pacientes nãocolaboradores admitiram que seus pais acham que suas notas escolares são insuficientes. Além disso, pacientes cooperadores afirmaram que obedecem aos desígnios ordenados pela professora. Esses resultados sugerem que a cooperação do paciente reflete uma atitude madura da personalidade de cada um.

CLEMMER; HAYES ${ }^{38}$, também, em 1979, realizaram um estudo buscando identificar pacientes colaboradores, além de promover medidas para estimular a cooperação dos pacientes. Os autores definem cooperação como o número de horas reais de uso do $A E B$ relativas às diretrizes do ortodontista. Uma amostra procedente da Universidade de Saint Louis, composta de 20 leucodermas, com idade média de 13,8 anos, foi submetida ao uso integral, ou por pelo menos 12 a 14h/dia, do AEB durante 2 a 3 semanas. Observaram pacientes cooperadores e não-cooperadores, sendo que $55,8 \%$ desses utilizaram o aparelho de acordo com as 
prescrições dos ortodontistas. Os autores verificaram que os pacientes super-colaboradores demonstravam alta cooperação escolar, maior sensibilidade na estética dentofacial; constituíam-se, em sua maioria, por mulheres, com melhor atitude geral durante o tratamento e que percebiam sua má oclusão como mais severa que o real. Os pacientes jovens não se apresentaram mais cooperadores. Houve diferença estatisticamente significante entre os gêneros, sendo que o feminino apresentou-se mais cooperador. A motivação do ortodontista deve basear-se na estética almejada para as meninas; já para os meninos, na responsabilidade adquirida diante do tratamento ortodôntico.

Segundo Mc DONALD ${ }^{94}$, a severidade da má oclusão rão se relaciona nem com a cooperação do paciente nem mesmo com o desejo de buscar o tratamento ortodôntico.

JARABAK $^{73}$, em 1965, afirma que a falta de cooperação do paciente pode destruir o melhor plano de tratamento e a mecânica mais promissora.

Existem alternativas para 0 tratamento de pacientes nãocolaboradores. Alguns ortodontistas atentam para medidas de motivação do paciente ${ }^{38}$. Contudo, como visto, a colaboração dos pacientes apresenta-se incerta e imprevisível, além de essencial em determinadas mecânicas ortodônticas. BATTSTRÖM; INGELSSON; ÄBERG ${ }^{13}$, em 1991, afirmaram que a principal causa para a descontinuidade do tratamento ortodôntico, na Suécia, era a falta de motivação dos pacientes. Em razão disso, vários autores desenvolveram mecânicas que independem da colaboração dos pacientes ${ }^{38}$, justamente por essa ser muito variável, inclusive na distalização dos molares superiores. 


\section{6 - DISTALIZADORES INDEPENDENTES DA COOPERAÇÃO DO PACIENTE}

\subsection{1 -MAGNETOS REPELENTES:}

A utilização dos magnetos na área biomédica iniciou-se na década de 1970, em que campos eletromagnéticos demonstraram sucesso em ortopedia médica para estimular e acelerar a atividade osteogênica, melhorando a cicatrização de ossos longos fraturados. Os magnetos foram primeiramente desenvolvidos e manufaturados com esse intuito pela ElectroBiology, Inc., os quais se encontram disponíveis até hoje, com algumas evoluções.

Já em 1978, BLECHMAN; SMILEY ${ }^{20}$, cogitaram a utilização das forças eletromagnéticas em Ortodontia. Em um estudo em animais, magnetos de AlNiCo (alumínio-níquel-cobalto) demonstraram constituir-se em um sistema alternativo no tratamento ortodôntico corretivo. Esses resultados sugeriram segurança biológica, eficácia mecânica e provavelmente, maior controle dos procedimentos mecânicos ortodônticos.

No início dos anos 1980, a empresa Medical Magnets Inc. desenvolveu um sistema baseado em pequenos magnetos terras raras para distalizar molares e também supuseram que esses magnetos geravam campos eletromagnéticos que, potencialmente, aceleravam a atividade osteogênica do lado de pressão, ou seja, na direção do movimento. ${ }^{19}$

O primeiro estudo relatando o emprego dos magnetos, na mecânica ortodôntica, em humanos, ocorreu em 1985, por BLECHMAN ${ }^{18}$. O autor relatou o tratamento de dois casos clínicos tratados exclusivamente pelos magnetos associados ao aparelho ortodôntico fixo convencional. Nenhum outro recurso mecânico foi utilizado. As mecânicas de fechamento dos espaços das extrações, elásticos de Classe II e a distalização dos molares superiores, foram realizadas pelos magnetos. Aplicou-se a força 
eletromagnética por um tempo médio de 1 ano e os tratamentos finalizaramse com sucesso.

A partir desse estudo, os magnetos intrabucais passaram a se constituir de samário-cobalto ( $\mathrm{SmCo}$ ), devido à maior resistência física, química e térmica, além da maior durabilidade do potencial magnético comparado ao AINiCo. ${ }^{18}$

A mecânica para a distalização dos molares superiores por meio dos magnetos foi primeiro reportada por GIANELLY et al. ${ }^{59}$, em 1988. Foram instalados magnetos repelentes num arco segmentado de primeiro pré-molar a primeiro molar superior, com extensão por distal do molar. Os magnetos foram contactados por meio da ativação com fio de amarrilho preso ao segundo pré-molar superior. A força de reação anterior foi ancorada por um Botão de Nance soldado às bandas dos primeiros prémolares superiores com extensão anterior até a face palatina dos incisivos superiores. A força produzida pelos magnetos compreendia 200 a $225 \mathrm{~g}$. Contudo, com a abertura de $1 \mathrm{~mm}$, a força atingia somente $75 \mathrm{~g}$. Devido a isso, as ativações foram semanais. Após sete semanas, os molares se encontravam em relação de Classe I. Como o paciente não possuía os segundos molares superiores irrompidos, os primeiros molares distalizaram $3 \mathrm{~mm}$ em apenas sete semanas. A proporção de distalização na presença dos segundos molares no arco usualmente se apresenta em 0,75 a $1 \mathrm{~mm} /$ mês. A perda de ancoragem constituiu-se em $1 \mathrm{~mm}$, não significativa. Com a obtenção da relação molar de Classe I, instaloutse um Botão de Nance para contenção e os pré-molares, caninos e incisivos superiores foram retraídos seqüencialmente, finalizando o tratamento.

Posteriormente, outros estudos foram realizados para avaliação dos efeitos decorrentes da distalização de molares superiores promovida pelos magnetos repelentes. $O$ intervalo das reativações variou de $1^{58}$ a 2 semanas $^{72}$. A distalização verificada apresentourse, em sua maioria, como de corpo na extensão de $2,1 \mathrm{~mm}$, com leve inclinação distal de $7,4^{\circ}$ e rotação de $6,2^{072}$. A protrusão dos dentes anteriores atingiu, em média, 
$1,2 \mathrm{~mm}$, com inclinação mesial de $3,8^{\circ 72}$, variando de 30 a $50 \%$ da distalização dos molares ${ }^{72}$ e $20 \%$ do movimento distal tota ${ }^{58}$. A força constituiurse em contínua e de intensidade aproximada de 8 onças $^{72}$ ou 200 a $225 \mathrm{~g}^{58}$. O tempo de tratamento compreendeu $2^{72}$ a 5 meses $^{58}$. Observouse que, na presença dos segundos molares superiores irrompidos, a distalização dos molares tornava-se mais lenta ${ }^{58}$. A principal dificuldade relatada pelos pacientes compreendeu o desconforto promovido pelo aparelho, em decorrência do tamanho dos magnetos e dificuldade de higienização. ${ }^{72}$. Os autores ${ }^{58,72}$ concluíram que os magnetos demonstramse muito efetivos na distalização dos molares superiores, sem necessitar da cooperação do paciente.

BLECHMAN $^{19}$, em 1998, atentou para as vantagens biológicas da mecânica realizada com os magnetos. De acordo com o autor, a movimentação ortodôntica provocada pelos magnetos proporciona menor sensibilidade dolorosa comparada às convencionais. A dor causada em decorrência da mecanoterapia convencional ocorre devido à maior reabsorção que aposição no local da movimentação, o que leva à mobilidade dentária e à dor conseqüente ao mastigar. A literatura sugere que campos eletromagnéticos controlam diretamente a mobilidade dentária por acelerar o metabolismo osteogênico, com o aumento da organização e da quantidade de novo osso depositado na área de tensão, exacerbando o potencial de cicatrização. Com isso, pelo menos parcialmente, há diminuição da dor e da mobilidade, pelo aumento da aposição em relação à reabsorção óssea. Além disso, o controle da dor caracteriza-se por ser um efeito direto de campos eletromagnéticos permanentes estáticos, agindo pela inibição sensorial neuronal. Com elação à distalização dos molares superiores, a literatura sugere que, para a distalização de um único molar, a força mínima requerida compreende $180 \mathrm{~g}$. Conseqüentemente, para distalizar o primeiro e segundo molares seriam necessários 300 a $350 \mathrm{~g}$. Porém, a experiência do autor demonstra que, em se tratando da força eletromagnética, apenas $160 \mathrm{~g}$ torna o movimento possível com menores efeitos colaterais. 


\subsection{2 - MOLAS DE NÍQUEL-TITÂNIO:}

Simultaneamente aos magnetos repelentes, em 1985, GHAFARP $^{50}$ propôs o uso de molas de níquettitânio para distalização unilateral de molares superiores. O sistema de ancoragem constituía-se em um Botão de Nance modificado, soldado à banda do primeiro molar superior em Classe I e ao primeiro pré-molar superior em Classe II. Um arco retangular segmentado de 0.019 " x 0.025" de NiTi foi instalado do primeiro pré-molar (em Classe II) aos molares a serem distalizados, onde uma mola de secção aberta NiTi foi moderadamente ativada entre o primeiro pré-molar e o primeiro molar, sendo que o segundo pré-molar permaneceu fora do arco. Com três reativações da mola, num período de 4 meses, obteve-se uma relação molar de Classe I. Decorridos mais 7 meses, finalizou-se o tratamento com sucesso.

Seis anos após, GIANELLY; BEDNAR; DIETZ ${ }^{57}$ introduziram alterações no sistema distalizador utilizado conjuntamente às molas de níquel-titânio. O sistema desenvolvido é instalado simultaneamente ao aparelho ortodôntico fixo. No fio retangular passivo 0.016 " x 0.022", adicionam-se ganchos ou stops próximos à região distal do bráquete do primeiro pré-molar superior. Nessa fase, o segundo pré-molar superior não se encontra colado. Esse stop tem por finalidade ativar a mola aberta $\mathrm{NiTi}$ superelástica japonesa localizada entre o bráquete do primeiro pré-molar e 0 tubo do primeiro molar superior, de comprimento aproximado de 8 a 10mm, promovendo uma distalização de 1 a 1,5mm/mês. A ancoragem é garantida pelo Botão de Nance soldado às bandas dos primeiros pré-molares superiores e por molas de verticalização localizadas nas canaletas verticais dos bráquetes dos mesmos dentes, de maneira a inclinar suas coroas distalmente. Na presença dos segundos molares superiores, a utilização de elásticos de Classe II auxilia na ancoragem, principalmente se a protrusão dos incisivos superiores exceder $1 \mathrm{~mm}$. Decorridos 5 a 6 meses, verificou-se a correção da relação molar de Classe II. A posição do molar é mantida pela inserção de stops por mesial aos tubos dos primeiros molares distalizados 
no fio $0.016 "$ " 0.022 " e pelo uso do AEB de tração alta, para verticalização das raízes dos mesmos.

Procurando quantificar os efeitos da distalização promovida pelas molas NiTi, PIERINGER; DROSCHL; PERMANN ${ }^{104}$, em 1997, avaliaram 8 pacientes entre 13 e 34 anos submetidos a esse tratamento. As molas liberavam força aproximada de 150 a $200 \mathrm{~g} / \mathrm{lado}$. A distalização média obtida constituiu-se em 5 a $10 \mathrm{~mm}$ em 10 meses de tratamento. Observourse significativa inclinação distal da coroa do primeiro molar movimentado, bem como inclinação vestibular, intrusão e rotação distovestibular, além da protrusão dos incisivos superiores. Apesar disso, os autores acreditam que esses efeitos provavelmente são corrigidos durante as fases subseqüentes do tratamento ortodôntico, o que viria a viabilizar o uso desse aparelho na prática ortodôntica.

\subsection{3 - MOLAS NÍQUEL-TITÂNIO X MAGNETOS:}

Visando a avaliar dois sistemas de força, os magnetos repelentes e as molas abertas de níquel-titânio superelásticas, BONDEMARCK; KUROL; BERNHOLD ${ }^{24}$, em 1994, compararam-nos intraindividualmente, atentando para os efeitos dentários e esqueléticos da distalização simultânea dos primeiros e segundos molares superiores, em indivíduos possuindo má oclusão de Classe II e sobremordida profunda. Os magnetos repelentes utilizados constituíam-se de cobalto-samário $\left(\mathrm{SmCo}_{5}\right)$ e as molas NiTi superelásticas eram japonesas, de comprimento $10 \mathrm{~mm}$, utilizados em conjunção a um plano de mordida anterior modificado ligado aos segundos pré-molares superiores. Esse tinha a função de ancoragem anterior e de desocluir os dentes posteriores, em aproximadamente 3 a $4 \mathrm{~mm}$, visando à distalização mais facilitada dos molares superiores e à correção da sobremordida profunda por meio do desenvolvimento vertical dos dentes posteriores. A distalização dos molares superiores transcorreu num período de 6 meses. Com a obtenção da relação molar de Classe I, 
uma barra transpalatina combinada a um Botão de Nance foram instalados. Utilizou-se da mecânica convencional para retração e alinhamento dos dentes anteriores. A força inicial aplicada por ambos os sistemas foi previamente calibrada em $225 \mathrm{~g}$, sendo que para isso os magnetos deveriam estar em contato e as molas ativadas em $7 \mathrm{~mm}$. Os resultados demonstraram que: 1) houve inclinação distal dos molares em torno de $10-15 \%$ do movimento total do molar; 2) ocorreu protrusão dos dentes anteriores de 1,5 a $2 \mathrm{~mm}$; 3) as queixas mais freqüentes aconteceram do lado dos magnetos, principalmente com relação à dificuldade de higienização; 4) observoutse abertura da mordida em decorrência das alterações verticais dentárias posteriores; 5) ambos os sistemas apresentaram-se efetivos na distalização simultânea do primeiro e segundo molar para a relação de Classe I, com a mínima inclinação dentária; 6) as molas superelásticas apresentaram-se mais efetivas que os magnetos repelentes, principalmente porque a força produzida pelas molas demonstrourse mais contínua que aquelas obtidas pelos magnetos. A força promovida pelas molas demorava a reduzir, atingindo, no mínimo $180 \mathrm{~g}$. Já para os magnetos, com a maior dstância entre os pólos, a força rapidamente diminuía para $100 \mathrm{~g}$. Os autores reportaram que os magnetos deveriam ser reativados semanalmente, o que é inviável clinicamente e as molas, num período de 5 a 6 semanas ou mais.

Devido a isso, posteriormente, ERVERDI; KOYUTÜRK; KÜÇÜKKELES ${ }^{44}$, em 1997, realizaram estudo similar, exceto pelo fato de que os magnetos foram reativados semanalmente, enquanto que as molas de níquel-titânio, mensalmente. A força inicial apresentou-se semelhante entre eles e, ao estudo anterior, em $225 \mathrm{~g}$. Verificou-se a relação molar de Classe I em todos os casos ao final de 3 meses. As alterações foram avaliadas em telerradiografias em norma lateral e modelos iniciais e pósdistalização. A distalização molar promovida pela mola NiTi apresentourse maior que aquela produzida pela força eletromagnética, em média, 1,6mm, quando medida na telerradiografia. De acordo com a análise dos modelos, a diferença compreendeu $1,4 \mathrm{~mm}$. Não houve diferença com relação à 
inclinação distal da coroa ou rotação distopalatina dos molares distalizados entre os dois procedimentos.

Conclui-se, por meio desses estudos, que as molas abertas de níquel-titânio comportaram-se mais efetivamente na distalização dos molares superiores comparadas aos magnetos repelentes, porém ambos são clinicamente aceitáveis. Os magnetos apresentaram-se menos eficientes devido, principalmente, à redução rápida da magnitude da força em proporção ao aumento da distância entre eles, chegando a 50-70\% menos a cada 0,5 a $1 \mathrm{~mm}$ de movimentação dentária. ${ }^{44}$

\subsection{4 - FIOS DE NÍQUEL-TITÂNIO:}

A utilização de fios superelásticos de níquettitânio (NiTi) como forma de distalização dos molares superiores foi inicialmente relatada por LOCATELLI et al. ${ }^{86}$, em 1992. No aparelho ortodôntico fixo, foram instalados stops no fio NiTi superelástico (NeoSentalloy 100g) por distal do tubo do primeiro molar e do bráquete do primeiro pré-molar superior, os quais quando inseridos permaneceram por mesial dos mesmos. Dessa forma, houve uma deflexão do fio NiTi superelástico que movimentou o primeiro molar para distal. A força média gerada compreendeu $100 \mathrm{~g}$. Para minimizar o efeito colateral da perda de ancoragem, os autores sugeriram o uso de elásticos de Classe II ou um Botão de Nance cimentado nos primeiros prémolares superiores. Os autores compararam a ação dos fios superelásticos $\mathrm{NiTi}$ aos magnetos e às molas NiTi superelásticas na distalização de molares superiores, chegando a $1-2 \mathrm{~mm}$ de movimento para distal por mês, com pequena perda de ancoragem anterior.

Para a distalização simultânea do primeiro e segundo molares superiores mais eficiente, GIANCOTTI; COZZA ${ }^{54}$, em 1998, propuseram um sistema de distalização baseado na formação de duas alças de deflexão com o fio NiTi superelástico NeoSentalloy de $80 \mathrm{~g}$. Além da deflexão do fio provocada pelos stops entre o primeiro pré-molar e o primeiro molar (o 
segundo pré-molar não foi inserido no arco), para distalizar o primeiro molar; outra alça de deflexão foi sugerida pelos autores, localizada entre a face distal do segundo pré-molar e a face mesial do segundo molar superior, formada por um segmento de fio (inserido apenas no segundo pré-molar e segundo molar), para a distalização somente do segundo molar superior. Indica-se o uso de molas de verticalização nas canaletas verticais dos primeiros pré-molares e elásticos de Classe II, para reduzir a perda de ancoragem. Verificou-se a relação molar de Classe I num período de 5 meses. Segundo os autores, esse sistema é ideal para a distalização simultânea do primeiro e segundo molares, já que a distalização por si só do segundo molar apresenta-se de mais fácil obtenção comparada ao primeiro molar, em função da forma anatômica diferente das raízes e da ausência de obstáculos mecânicos posteriores; em decorrência disso, os primeiros molares superiores requerem menores forças para distalizar, em torno de $80 \mathrm{~g}$, devido à ação das fibras transeptais, que tracionam o dente em direção ao movimento realizado pelo segundo molar. Também, o controle de ancoragem torna-se mais fácil, sem a necessidade do Botão de Nance ou barra transpalatina, requerendo a mínima cooperação do paciente.

\subsubsection{1 - Outras formas de distalizacão com o uso dos fios NiTi}

Diferentemente dos autores acima citados, que se utilizaram da deflexão do fio NiTi para a distalização dos molares superiores, KALRA ${ }^{77}$, em 1995, desenvolveu uma alça em forma de "K" invertido, que promovia um momento de força distal e outro para verticalização das raízes, minimizando a inclinação distal da coroa do molar. Segundo o autor, o movimento resultante compreendia a translação, caracterizando um movimento de corpo. A alça "K" foi confeccionada com fio TMA 0.017 "x0.025", que pode ser ativado duas vezes mais que 0 aço inoxidável antes da deformação permanente. A ancoragem é exercida pelo Botão de Nance soldado às bandas dos primeiros pré-molares superiores. Reativourse a alça a cada 6 ou 8 semanas, por meio da sua abertura numa extensão de $2 \mathrm{~mm}$. Observout 
se que a perda de ancoragem aconteceu numa proporção de 1:4 mm de distalização do primeiro molar superior, semelhantemente aos magnetos $\mathrm{e}$ às molas NiTi. Se necessário, a ancoragem pode ser reforçada com o uso do AEB, tração cervical ou alta, com força de $150 \mathrm{~g}$ nos pré-molares. As principais vantagens da alça "K" constituem-se: simples confecção e instalação; eficiência satisfatória; higiênica; confortável ao paciente; baixo custo; controle da proporção força-momento para produzir movimento de corpo; requer mínima cooperação do paciente.

Mais recentemente, MANDURINO; BALDUCC ${ }^{p 0}$, em 2001, propuseram a utilização de uma barra transpalatina para a distalização unilateral de molar superior, em casos de Classe II assimétrica. A barra transpalatina foi confeccionada com fio TMA 0.032 ", sem a necessidade da realização da alça central, já que não se almeja pela expansão maxilar. $A$ barra é inserida nos tubos linguais dos primeiros molares superiores, de maneira a encaixar, por distal, no tubo do molar a ser utilizado como ancoragem (em Classe I) e, por mesial, no tubo do molar a ser distalizado. As ativações foram realizadas por meio de uma dobra de $30^{\circ}$ voltada para distal ao molar a ser distalizado, mensalmente. $O$ efeito produzido no molar de ancoragem consistiu numa tendência de rotação mesiovestibular, sendo por isso recomendada a utilização do aparelho ortodôntico fixo instalado até o segundo molar superior em fio retangular. Já no molar, em Classe II, a força resultante incide para distal, recomendando-se, ainda, o uso noturno do AEB. Os autores alertam para a possível ocorrência de fraturas do fio TMA intrabucalmente, atentando para as vantagens da fácil confecção do aparelho, fácil higienização, baixo custo e ausência da perda de ancoragem, com a distalização espontânea dos pré-molares e caninos devido à ação das fibras transeptais. 


\subsection{5 - APARELHO DE NANCE MODIFICADO:}

Com o intuito de distalizar os molares superiores, REINER ${ }^{108}$, em 1992, modificou o Botão de Nance por meio da inclusão de um sistema semelhante a um bihélice na região central do botão de resina acrílica. Já que o caso apresentado tratava-se de uma Classe II unilateral, somente no lado Classe II (a ser distalizado) instalourse uma mola de secção aberta da face mesial do tubo lingual do primeiro molar até a extremidade de um ômega confeccionado a partir de fio de aço inoxidável 0.020 " e soldado por lingual do primeiro pré-molar. A ativação ocorria por meio da abertura desse ômega, sendo por volta de $7 \mathrm{~mm}$, o que resultava em uma força de $150 \mathrm{~g}$. Vale salientar que, do lado passivo, o fio foi soldado na banda do primeiro molar e, do lado ativo, ele inseria-se num tubo lingual do molar em Classe II. O primeiro e segundo molares foram distalizados para uma relação de Classe I numa média de $0.19 \mathrm{~mm}$ por semana, sendo que, no lado contralateral, a relação de Classe I permaneceu estável. Houve pouca perda de ancoragem.

As fases da mecânica ortodôntica subseqüente à distalização dos molares superiores realizada por meio do aparelho de Nance modificado foram descritas por PUENTE ${ }^{106}$, em 1997. O autor atentou para a importância do posicionamento dos tubos linguais dos molares a serem distalizados, que previnem a inclinação distal da coroa, produzindo movimento de corpo aproximado de 0,75 a $1 \mathrm{~mm} / \mathrm{mês}$. Obtida a distalização do primeiro molar, o aparelho de Nance mantém-se fixo em posição passiva por meio de um amarrilho entre o tubo lingual do molar e o helicóide do aparelho de Nance. Em arcos de aço inoxidável de 0.016"ou 0.018" redondos com ômega confeccionado por mesial dos tubos molares, inicia-se a retração do segundo pré-molar superior por meio de molas NiTi ou cadeias elastoméricas. Segue-se a distalização do primeiro pré-molar e de todos os dentes ântero-superiores. Nessa fase, substitui-se o Botão de Nance modificado por uma barra transpalatina e/ou elástico de Classe II. A retração ântero-superior deve ser realizada preferencialmente em fio 0.017 " $\times 0.025$ ". 
O aparelho de Nance modificado demonstrou sucesso na correção da Classe II associada à extração do segundo molar superior ou não, em pacientes com protrusão maxilar, perfil facial aceitável e padrão de crescimento facial favorável.

\subsection{6 - JONES JIG:}

O aparelho Jones Jig foi preconizado por JONES; WHITE ${ }^{76}$, em 1992. O dispositivo para distalização é pré-fabricado com fio de aço inoxidável 0.045", que é inserido no tubo do aparelho extrabucal. Esse estende-se até a região dos caninos, onde se encontra uma mola de secção aberta de NiTi. Próximo ao molar, há uma extensão para inserção no tubo molar (do arco principal) e um gancho, onde um amarrilho deve ligar o dispositivo ao tubo molar, servindo como retenção do aparelho. As molas são ativadas com fio de amarrilho unindo-as ao bráquete do segundo prémolar superior. As reativações ocorrem num intervalo de 4 a 5 semanas, liberando uma força de 70 a $75 \mathrm{~g}$, numa compressão de 1 a $5 \mathrm{~mm}$. A ancoragem é fornecida pelo Botão de Nance cimentado nos segundos prémolares. Feita a distalização, instala-se um Botão Palatino de Nance nos primeiros molares para contenção. De acordo com os autores, a duração do tratamento varia segundo o tipo de Classe II. Se a Classe II for conseqüente a uma rotação da cúspide mesiovestibular, o tratamento dura em média 90 a 120 dias. Por outro lado, se uma "verdadeira" Classe II dentária estiver presente, o período de tratamento prolonga-se de 120 a 180 dias. Os autores contra-indicam o uso do Jones Jig para pacientes com padrão de crescimento extremamente vertical, pois não se restringe a extrusão dos molares com a utilização desse aparelho. A protrusão dos incisivos superiores caracterizourse como insignificante, com exceção dos casos em que o aparelho fixo já se encontrava instalado previamente ao Jones Jig. Provavelmente, nesses pacientes, a protrusão ocorreu devido ao efeito protrusivo dos arcos iniciais de nivelamento. Obteve-se a distalização 
necessária dos molares superiores em todos os casos tratados, sem a necessidade da cooperação do paciente.

Buscando analisar os efeitos dentários e esqueléticos proporcionados pelo aparelho Jones Jig, RUNGE; MARTIN; BUKAl ${ }^{15}$, em 1998, avaliaram telerradiografias em norma lateral inicial e pós-correção da relação molar. $O$ intervalo entre elas compreendeu, em média, 9 meses. Os resultados mostraram que houve: 1) movimento distal significativo dos primeiros e segundos molares superiores, concomitantemente; 2) movimento linear e de inclinação mesial significativo da unidade de ancoragem; 3) aumento do trespasse horizontal e da altura facial ântero-inferior ; e 4) rotação distopalatina do molar distalizado, produzindo mordida cruzada posterior. Os autores sugerem a utilização de ancoragem adicional nos prémolares representada pelo aparelho extrabucal.

Com o objetivo de comparar os efeitos do aparelho extrabucal com o aparelho Jones Jig na correção da Classe II dentária, HAYDAR; ÜNER ${ }^{67}$, em 2000, estudaram 20 pacientes com idade média de 10,6 anos, sendo 10 casos tratados com o AEB, exercendo força de $600 \mathrm{~g} / \mathrm{lado}$ por 16h/dia e os demais pacientes, com o aparelho Jones Jig convencional. A ativação compreendeu $5 \mathrm{~mm} / \mathrm{mês}$. Analisaram-se as telerradiografias inicial e final. O ângulo SNA diminuiu significantemente no grupo do AEB, assim como o plano palatino inclinou para trás. Nenhum efeito esquelético foi constatado no grupo tratado com o Jones Jig. Com relação aos efeitos dentários, com o uso do $\mathrm{AEB}$, os incisivos superiores extruíram e retraíram, enquanto que com o Jones Jig, houve inclinação vestibular e protrusão. Esse efeito também foi observado nos pré-molares, ou seja, distalização com ○ AEB e mesialização com o Jones Jig. Verificou-se significativa extrusão dos primeiros molares superiores no grupo Jones Jig. Uma das principais diferenças entre eles constituiurse no tempo de tratamento mais curto com o uso do Jones Jig, sendo 2,5 meses para o Jones Jig e 10,7 meses com o AEB, ou seja, o tempo total de tratamento reduz-se em pelo menos 6 a 8 meses com o uso do Jones Jig. 
Outros autores ${ }^{121,123}$ revisaram todos os aspectos concernentes ao aparelho Jones Jig, visando a orientar clínicos com relação ao seu emprego no consultório odontológico. Salientou-se sobre a preferência da soldagem do tubo molar o quanto mais por gengival possível, de maneira a proporcionar um momento de força distal mais próximo do centro de resistência do molar, com um conseqüente movimento mais de corpo que inclinação coronária. ${ }^{123}$ As principais vantagens do aparelho Jones Jig compreendem: independe da colaboração do paciente; é estético, não trazendo impacto anti-social; bem aceito pelo paciente; distaliza molares com força suave, de natureza contínua (característica das ligas NiTi); menor sensibilidade e mobilidade dos molares durante a distalização; eficiência nas pequenas distalizações, sobretudo nas unilaterais. ${ }^{121}$ Por outro lado, as desvantagens constituíram-se: número maior de procedimentos clínicos para a sua instalação; necessidade da bandagem dos pré-molares; ancoragem insuficiente para distalizações simétricas; impossibilidade de controle do centro de rotação durante a distalização dos molares; obtém-se movimento de corpo apenas inicialmente, sendo que o restante caracteriza-se pela inclinação; não promove efeito ortopédico em Classe II esqueléticas; dificulta a higienização. ${ }^{121}$ Os autores concluem que desde que bem indicado, o distalizador Jones Jig possibilita uma rápida resolução do caso, com efeitos colaterais controláveis e com a mínima cooperação do paciente. ${ }^{123}$.

\subsection{7 - PISTÃO:}

A distalização dos molares superiores com um sistema pistão foi apresentada por GREENFIELD ${ }^{64}$, em 1995. O aparelho constitui-se por bandas nos primeiros pré-molares e primeiros molares superiores. Nas bandas dos primeiros pré-molares, soldam-se tubos de 0.036" de diâmetro por vestibular e lingual. Nas bandas dos primeiros molares, fios de aço inoxidável 0.030 " são soldados por vestibular e lingual também, de maneira a encaixar nos tubos soldados nos primeiros pré-molares. Uma mola de níquel-titânio de secção aberta 0.055 " localiza-se passivamente em toda a 
extensão desse sistema. A ativação ocorre quando da colocação de anéis de aço por mesial às molas, de maneira a comprimi-las em $2 \mathrm{~mm}$ a cada 6 a 8 semanas. Isso providencia uma força de aproximadamente $25 \mathrm{~g}$ em cada pistão ou $50 \mathrm{~g}$ por dente. A ancoragem é garantida por um Botão de Nance soldado às bandas dos primeiros pré-molares. Após 6 meses de tratamento, obteve-se $5 \mathrm{~mm}$ de distalização do molar superior. A seguir, os dentes ântero-superiores foram retraídos, alinhados e nivelados. As principais vantagens oferecidas por este sistema consistem: produz movimento de corpo dos molares distalizados, minimizando ou anulando a recidiva; não requer a cooperação do paciente; higienização adequada; reduz o tempo de tratamento nos casos sem extrações, desde que a distalização acontece na proporção de 1mm/mês; verifica-se sobrecorreção decorridos 6 a 9 meses de tratamento; força leve e controlada; não interfere no plano oclusal, com controle da dimensão vertical; se necessário, pode-se utilizar o AEB (há tubos duplos ou triplos nos primeiros molares superiores).

\subsection{8 - DISTAL JET:}

O Distal Jet foi introduzido em 1996, por CARANO; TESTA ${ }^{34}$. Nesse estudo e em outro posterior ${ }^{33}$, também em 1996, os autores descrevem o aparelho, atentando para suas indicações e efeitos promovidos. O aparelho consiste em um Botão de Nance soldado aos segundos pré-molares superiores. Tubos bilaterais de 0.036 " de diâmetro ligam-se ao acrílico do Botão de Nance e inserem-se em fios instalados nos tubos linguais dos primeiros molares superiores. Entre o tubo e o fio encontram-se molas de $\mathrm{NiTi}$ de $150 \mathrm{~g}$ para crianças e $250 \mathrm{~g}$ para adultos, ativadas de acordo com a proximidade ou não de um parafuso. A reativação ocorre mensalmente pelo ajuste desse parafuso, de forma a comprimir a mola NiTi. Após a conversão da Classe II de molar em Classe I, o distalizador lingual é convertido em aparelho de contenção de Nance, por meio do desligamento dos pré-molares da estrutura do aparelho e da estabilização das molas de ativação com a colocação de resina acrílica 
sobre elas. A distalização média constituiu-se de 3 a $5 \mathrm{~mm}$, em 4 meses. A proporção de movimentação dos molares apresentou-se semelhante àquela observada pelos magnetos repelentes ou Jones Jig, contudo sem a inclinação e a rotação verificadas nestes. A distalização obtida caracterizour se como movimento de corpo. A unidade de ancoragem dos pré-molares e incisivos permaneceu praticamente estável. Os autores ressaltam para as vantagens deste aparelho que não requer a cooperação dos pacientes, é estético, promove distalização de corpo e, se necessário for, assimétrica.

Algumas modificações na estrutura do Distal Jet foram sugeridas por $\mathrm{BOWMAN}^{25}$, em 1998, com o intuito de facilitar o seu manuseio clinicamente. A primeira modificação diz respeito à conversão do Distal Jet em Botão de Nance. Em vez da colocação de resina acrílica na mola aberta, o autor recomenda que um amarrilho 0.014" seja inserido entre o tubo lingual do molar e do stop de ativação, de forma a manter estável o comprimento da mola NiTi. Outra forma seria a inserção de dois parafusos para ativação da mola. Finda a distalização, remove-se a mola aberta por meio de alicate específico e um parafuso é rosqueado no final do tubo e outro no início do fio, um junto ao outro na região da união tubo/fio, tornando o segmento único e bem firme. O fio unindo o pré-molar à parte acrílica é removido do sistema por meio de uma broca diamantada. Para correção da rotação do molar, o autor indica a confecção de um helicóide previamente à inserção do fio no tubo lingual do molar. Por meio de ajuste proporcionado por esse helicóide, corrige-se a rotação do molar, se necessário. Freqüentemente, não há necessidade da expansão maxilar durante a distalização dos molares, a menos que uma mordida cruzada posterior esteja presente inicialmente. Se for necessária uma expansão muito significativa, indica-se a realização da expansão maxilar previamente à distalização do molar. Porém, se a expansão maxilar requerida for pequena, adiciona-se um parafuso expansor no Botão de Nance para a realização da expansão maxilar concomitantemente à distalização dos molares com 0 Distal Jet. 
Também QUICK; HARRIS ${ }^{107}$, em 2000, sugeriram modificações no Distal Jet devido à dificuldade da realização intrabucal das reativações, em decorrência do pequeno tamanho do parafuso de ativação e o perigo eminente da deglutição ou aspiração da chave utilizada para as reativações. O aparelho modificado consiste num fio de aço de 0.030 " ou 0.032 " que se insere por distal ao tubo lingual do primeiro molar superior. Esse é estabilizado por um fio de amarrilho ou elastômero, preferencialmente com o fio de amarrilho. A seguir, esse fio acopla-se a um tubo adaptado ao Botão de Nance. Uma mola de NiTi localiza-se entre a parte final do tubo e o fio 0.30 " ou 0.032 ", sendo que sua ativação se dá por um stop soldado no fio de aço. Para a realização das reativações, basta a remoção do fio de amarrilho do tubo lingual do primeiro molar superior e do fio de aço, em seguida, com a colocação de um comprimento maior de mola $\mathrm{NiTi}$. Com isso, as inconveniências apresentadas pelo parafuso para reativação foram eliminadas, facilitando o processo das ativações.

A distalização dos molares superiores obtida com o Distal Jet suscitou BOWMAN ${ }^{26}$, em 1998, a formular uma terapia combinada para a Classe II. O objetivo da terapia caracteriza-se pelo sucesso do tratamento da Classe II, com a mínima cooperação do paciente, melhorando assim o seu prognóstico. A terapia constitui-se em três estágios: 1) na dentadura mista tardia, instala-se um arco lingual inferior para manutenção do Leeway Space e correção de pequenos apinhamentos. Nessa fase, realiza-se a distalização dos molares superiores por meio do Jones Jig ou Distal Jet. A obtenção da relação molar de Classe I se dá em 4 a 6 meses. Os arcos dentários inferior e superior são alinhados e nivelados simultaneamente à distalização; 2) manutenção da distalização com o Botão de Nance. O autor demonstra predileção pelo Distal Jet pela facilidade da sua conversão em Botão de Nance; 3) instalação do Jasper Jumper para manter a distalização do molar superior, prover ancoragem para a retração ântero-superior e promover efeitos ortopédicos para a correção da Classe II. Com isso, haverá um menor potencial de recidiva comparado ao uso precoce do aparelho 
funcional somente, já que a intercuspidação obtida no sistema proposto assegura uma maior estabilidade. Realiza-se a distalização dos pré-molares mecanicamente, caso essa não aconteça espontaneamente. Decorridos 6 a 9 meses, todos os espaços são fechados. Após os procedimentos de finalização, a contenção é instalada. As principais vantagens oferecidas pela terapia compreendem: redução da colaboração do paciente durante o tratamento; rapidez no tratamento, realizado em uma só fase ortopédico-fixo. A terapia está contra-indicada nos casos em que há um apinhamento severo, biprotrusão esquelética; ângulo do plano mandibular obtuso e mordida aberta.

Existem poucos trabalhos relatando os resultados obtidos após a finalização da terapia ortodôntica fixa subseqüente à distalização dos molares superiores. Somente NGANTUNG; NANDA; BOWMAN ${ }^{99}$, em 2001, avaliaram longitudinalmente, em telerradiografias em norma lateral, os efeitos da distalização do molar superior com o aparelho Distal Jet no período de finalização do aparelho ortodôntico fixo. A amostra consistiu de 33 pacientes com idade média de 12,8 anos, possuindo $1 / 2$ Classe II. As molas $\mathrm{NiTi}$ utilizadas promoviam força de $240 \mathrm{~g}$. O alinhamento e nivelamento ocorreram simultaneamente à distalização molar, sendo que a correção da Classe II se deu em 6,7 meses. Obtida a sobrecorreção, houve a conversão do Distal Jet em Botão de Nance, permitindo a distalização espontânea dos pré-molares superiores pela ação das fibras transeptais. Para a contenção, foram utilizados o Botão de Nance associado ao Jasper Jumper, proporcionando ancoragem para a retração ântero-superior e algum efeito ortopédico. $O$ tempo total de tratamento compreendeu 25,7 meses. As alterações observadas no período logo após a distalização molar consistiram em: distalização de 2,1 $\mathrm{mm}$ e inclinação distal de 3,30 dos primeiros molares superiores; mesialização de 2,6mm e inclinação distal de 4,3ํำ dos segundos pré-molares superiores; distalização de $2,6 \mathrm{~mm}$ e inclinação distal de $11,8^{\circ}$ dos segundos molares superiores; inclinação vestibular dos incisivos superiores de $12,2^{\circ}$ e protrusão de $1,7 \mathrm{~mm}$; houve efeito insignificante no 
plano palatino; a AFAI aumentou 2,4mm; o lábio superior e inferior protruíram $0,8 \mathrm{~mm}$ e $2,1 \mathrm{~mm}$, respectivamente. Já as alterações no final do tratamento ortodôntico fixo compreenderam: mesialização de 3,9mm, verticalização de $6,1^{\circ}$ e extrusão ou irrupção de $1,4 \mathrm{~mm}$ dos primeiros molares superiores; os segundos molares superiores mesializaram $3,4 \mathrm{~mm}$, extruíram $4 \mathrm{~mm}$ e verticalizaram 14,6우 ; os segundos pré-molares distalizaram $0,9 \mathrm{~mm}$, inclinaram para mesial $2,1^{\circ}$ e não demonstraram alterações verticais; os incisivos superiores inclinaram para lingual 6,8ำ extruíram 1,8mm; houve efeito mínimo no plano palatino, plano oclusal e no FMA; a AFAl aumentou 1,2mm, porém a proporção entre altura facial ântero-inferior e altura facial total diminuiu, concluindo-se que provavelmente esse aumento ocorreu devido ao desenvolvimento facial normal; os lábios superior e inferior retruíram 2,2 e 2,1mm respectivamente. Além disso, não houve diferença estatisticamente significante no movimento do molar ou perda de ancoragem baseado no gênero ou no FMA inicial. Segundo os autores, os resultados parecem surpreendentes principalmente para os clínicos, já que os molares superiores mesializaram ao final do tratamento comparados à fase pós-distalização e mesmo à fase inicial. Contudo, a relação de Classe I obtida manteve-se até o final do tratamento, o que permite concluir que essa mesialização tanto do molar superior quanto do inferior deveurse ao crescimento facial normal. Ou seja, a compensação dentoalveolar foi interrompida durante a correção da Classe II, permitindo uma nova relação molar, que se manteve na finalização do tratamento ortodôntico.

\subsection{9 - PARAFUSO EXPANSOR:}

Em 1999, FORTINI; LUPOLI; PARR ${ }^{48}$ propuseram um novo tipo de aparelho para distalização dos molares superiores uni ou bilateralmente, baseados na modificação do Distal Jet pela incorporação por vestibular de um parafuso expansor, com a finalidade de diminuir a perda de ancoragem. A estrutura do aparelho consiste na soldagem de um parafuso expansor por oclusal do tubo molar convencional (preferencialmente 
simples) na superfície vestibular do primeiro molar superior. Um anel de aço é soldado no segundo pré-molar por vestibular para a inserção da parte anterior de ativação do parafuso expansor. Por lingual, instala-se um Botão de Nance modificado, apresentando uma estrutura metálica em formato de borboleta, com uma mola NiTi 0.010 "x 0.045 " entre o primeiro molar e o segundo pré-molar, aumentando a ação do parafuso expansor por vestibular e prevenindo a rotação e o cruzamento do molar durante a distalização. As indicações para sua utilização compreendem: Classe II dentárias ou esqueléticas caracterizadas pela protrusão maxilar, no período de crescimento; sobremordida profunda; Classe II esqueléticas, quando há falta de cooperação do paciente, limitando a efetividade dos aparelhos funcionais e Classe II dentárias com discrepância de modelo negativa no arco dentário superior. A partir do tratamento de 62 pacientes, com idade entre 8,7 anos a 14,5 anos, os autores observaram uma distalização média de $4,8 \mathrm{~mm}$, independentemente da presença ou não dos segundos molares. Observout se distalização de corpo, sem efeito de inclinação. O tempo médio para a distalização consistiu de 42 dias, sendo que não houve perda de ancoragem nem alteração da AFAl.

\subsubsection{0 - DISTALIZADOR DE CORPO:}

O aparelho intrabucal distalizador de corpo dos molares superiores foi desenvolvido por KELES; SAYINSU79, em 2000, com o objetivo de movimentar os molares de corpo para distal sem inclinação, eliminar a cooperação do paciente e minimizar o tempo de tratamento. $O$ aparelho constitui-se de um Botão de Nance soldado às bandas dos primeiros pré-molares que se estende até a face palatina dos incisivos, aumentando a área de ancoragem, associado a um plano de mordida anterior destinado à desoclusão dos dentes posteriores, facilitando a distalização. Para a distalização dos molares, molas confeccionadas com fio de TMA 0.032"x 0.032" são inseridas no acrílico do Botão de Nance. Essas molas possuem dois helicóides, um localizado logo na emersão da mola do 
acrílico e outro próximo à face palatina dos molares, formando um "U". Dessa forma, há dois componentes de força: um momento de distalização que aplica uma força de inclinação na coroa e outro, de verticalização das raízes dos primeiros molares superiores. A força distal totaliza $230 \mathrm{~g}$. Esse aparelho foi instalado em 15 pacientes, com idade média de 13,5 anos. Avaliourse as telerradiografias em norma lateral e modelos iniciais e pósdistalização. Verificou-se uma relação molar Classe I num período de 7,5 meses, com uma distalização média de corpo de $5,23 \mathrm{~mm}$. Os primeiros prémolares mesializaram $4,33 \mathrm{~mm}$ e extruíram $3,33 \mathrm{~mm}$, inclinando mesialmente 2,73․ Observoutse protrusão dos incisivos de $4,77 \mathrm{~mm}$ e vestibularização de $6,73^{\circ}$. O trespasse horizontal aumentou $4,1 \mathrm{~mm}$ e o trespasse vertical reduziu em 2,63mm. Os primeiros molares inferiores extruíram 1,53mm. A análise dos modelos mostrou que os molares não apresentaram rotação nem houve alteração transversal durante sua distalização, pelo melhor controle transversal proporcionado pela mola confeccionada com fio de secção quadrada. O ângulo SNA aumentou $1,56^{\circ}$ e o ANB em 1,66을 devido à vestibularização dos incisivos superiores, o que provocou a remodelação do ponto A. Os autores reconhecem a necessidade de mais estudos na segunda fase do tratamento, em que se realiza a retração dos dentes ântero-superiores, para examinar a estabilidade dos molares distalizados.

\subsubsection{1 - O APARELHO PENDULUM}

O aparelho Pendulum, cujos efeitos serão investigados no presente estudo, foi preconizado por HILGERS ${ }^{70}$, em 1992, objetivando o tratamento da Classe II com mínima colaboração do paciente. O aparelho consiste de um botão de resina acrílica localizado no palato, que serve como ancoragem e molas construídas com fio de titânio-molibdênio (TMA) 0.032", as quais se encaixam nos tubos linguais dos molares, exercendo forças moderadas e contínuas, já que o fio TMA permite uma deflexão duas vezes 
maior que o aço inoxidável previamente à deformação permanente ${ }^{28}$. As molas são adaptadas ao palato e possuem uma pequena alça horizontal para facilitar os ajustes transversais, um helicóide e uma alça para a retenção no corpo de resina. A denominação do aparelho baseia-se na forma com que as molas agem, como se fosse um pêndulo, partindo da linha média do palato em direção aos molares superiores. A porção anterior do aparelho é estabilizada de várias formas. Originalmente, fez-se por meio de apoios oclusais colados nos molares decíduos ou nos primeiros e segundos pré-molares. Porém HILGERS ${ }^{70}$ afirma que o método mais estável de retenção do aparelho consiste na cimentação de bandas nos primeiros prémolares ou primeiros molares decíduos e grampos de apoios oclusais nos segundos pré-molares. Essas extensões podem ser removidas durante 0 tratamento, para permitir o deslocamento natural dos segundos pré-molares para distal. Havendo a necessidade de expansão transversal, adapta-se um parafuso expansor no acrílico da região mediana do palato, transformandose no aparelho denominado Pend- $X$, que nada mais é do que uma modificação do aparelho original.

\section{Ativação do aparelho Pendulum:}

HILGERS $^{70}$ recomenda a pré-ativação das molas TMA. As molas devem ser ativadas paralelamente à linha mediana do palato (ou perpendicularmente ao corpo do aparelho). À primeira vista, parece uma super-ativação, mas cerca de $1 / 3$ da mesma perde-se na instalação do aparelho e a pressão restante é facilmente suportada pelo paciente, refletindo em $250 \mathrm{~g}$ de força por lado. A pressão da mola deve ser checada de 3 em 3 semanas. Se requerida a reativação, emprega-se um alicate 139 no centro do helicóide empurrando-o distalmente em direção à linha média, sem a necessidade da remoção do aparelho.

ALMEIDA et al. ${ }^{3}$, em 1999, recomendou modificações na estrutura do aparelho, para que as molas sejam reativadas extrabucalmente, 
de forma a facilitar sua execução e maximizar o controle da movimentação dos molares, já que evita a incorporação de distorções nas molas. Para isso, os autores propuseram que as molas TMA sejam removíveis, proporcionando sua fácil remoção do aparelho, ativação extrabucal e nova reinserção, sem a necessidade da remoção de todo o sistema. $O$ aparelho é construído de maneira convencional, porém para a fixação das molas incorpora-se, durante a acrilização do aparelho, duas extensões de $10 \mathrm{~mm}$ de tubos telescópicos de aço inoxidável 0.049"x 0.033" da marca Tecnident (código TT-009) posicionados paralelamente à sutura palatina mediana. Ativa-se as molas extrabucalmente e, após a fixação do aparelho, essas são inseridas nos tubos telescópicos e, posteriormente, nos tubos linguais dos primeiros molares superiores.

Esse mesmo tipo de modificação foi proposta por SCUZZO et al. ${ }^{118}$, em 2000. Para que as molas de TMA tornem-se removíveis, esses autores sugeriram a confecção de um sistema de encaixe durante a confecção do Botão de Nance. As principais vantagens do sistema são: redução do tempo de cadeira, movimentação de $1,5 \mathrm{~mm} / \mathrm{mês}$; melhor controle da força empregada; resultados mais precisos; menor ocorrência de efeitos adversos, conversão do aparelho Pendulum em Botão de Nance somente pelo encaixe de fios de aço inoxidável passivos.

Se durante a distalização ocorrer uma mordida cruzada do molar superior, HILGERS ${ }^{70}$ recomenda a abertura da alça horizontal em aproximadamente $15 \%$, promovendo a expansão transversal e a correção da rotação distopalatina indesejada.

\section{Indicações:}

De acordo com HILGERS ${ }^{70}$, MACEDO, AIDAR ${ }^{87}$; e RONDEAU ${ }^{113}$, as principais indicações do aparelho Pendulum compreendem: 
- comprimento de arco superior deficiente devido a uma perda precoce dos molares decíduos;

- relação molar de Classe II;

- distalizações de molares superiores uni ou bilaterais;

- pacientes não colaboradores;

- pacientes braquifaciais;

Além disso, o tratamento é mais indicado para pacientes com boa relação esquelética dos maxilares (Classe I) ${ }^{113}$, quando o sucesso da terapêutica é facilmente obtido, como verificado em caso clínico apresentado por WONG; RABIE; HÄGG ${ }^{130}$, em 1999. A paciente possuía 13 anos de idade, Classe II, divisão 2 completa e apinhamento superior de $6 \mathrm{~mm}$. O tratamento foi realizado por meio da extração dos segundos molares superiores e distalização dos primeiros molares com o aparelho Pendulum, que ocorreu num período de 6 meses. Após a obtenção da relação molar de Classe I, o aparelho Pendulum foi mantido como contenção por 4 meses, seguido pela instalação do aparelho ortodôntico fixo para alinhamento e nivelamento dentários. Decorridos 24 meses, o tratamento finalizou com sucesso.

\section{Contra-indicações:}

A maior contra-indicação apontada por HILGERS ${ }^{70}$ diz respeito aos pacientes dolicofaciais, em decorrência da tendência de abertura da mordida anterior promovida pelo uso do aparelho Pendulum.

Contudo, MACEDO; AIDAR $^{87}$, em 2001, obtiveram sucesso no tratamento distalizador com o aparelho Pendulum em uma paciente Classe II dentária, perfil facial satisfatório e padrão de crescimento com suave tendência vertical $\left(F M A=34^{\circ}\right)$. Observaram inclusive melhora no padrão vertical com o emprego dessa mecânica, passando de hiperdivergente para neutro, de acordo com os critérios da análise de Jarabak. 


\section{Efeitos ocasionados pelo aparelho Pendulum:}

HILGERS $^{70}$, em 1992, afirmou que o aparelho Pendulum proporciona um movimento distal dos molares superiores de $5 \mathrm{~mm}$, num período de 3 a 4 meses.

Posteriormente, outros autores como GHOSH; NANDA ${ }^{52}$, em 1996 e BYLOFF; DARENDELILER ${ }^{30}$, em 1997, realizaram estudos para avaliar os efeitos decorrentes da utilização do aparelho Pendulum ${ }^{52}$ e Pend$X^{30}$ em pacientes Classe II, por meio da análise de telerradiografias em norma lateral e modelos iniciais e pós-distalização. Os resultados mostraram que:

- a proporção de distalização compreendeu $1,02 \mathrm{~mm} / \mathrm{mês}^{30}$, sendo em média de $3,37 \mathrm{~mm}^{52}$ a $4,08 \mathrm{~mm}^{30}$;

- o período médio de tratamento consistiu em 4 meses ${ }^{30}$;

- a perda de ancoragem compreendeu $2,55 \mathrm{~mm} ;{ }^{52}$

- a presença dos segundos molares superiores não interferiu na distalização obtida; ${ }^{30,52}$

- a inclinação distal do primeiro molar superior apresentou-se acentuada em $14,5^{\circ}{ }^{30}$ e menor noutro estudo, em 8,36‥52

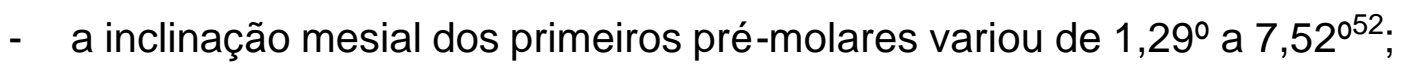

- o espaço criado deveu-se em $75 \%$ pela distalização dos molares e $25 \%$ pela mesialização dos pré-molares ${ }^{30}$, diferentemente dos dados obtidos por GHOSH; NANDA ${ }^{52}$, em que de cada $1 \mathrm{~mm}$ de distalização ocorreu $0,75 \mathrm{~mm}$ de mesialização dos pré-molares;

- houve intrusão dos primeiros molares superiores ${ }^{30}$, porém em outro estudo $^{52}$ essa não foi significativa;

- ocorreu extrusão dos segundos pré-molares ${ }^{30}$ e dos primeiros prémolares superiores em $1,7 \mathrm{~mm}^{52}$; 
- observou-se alterações transversais, representadas pelo aumento na distância entre os primeiros molares superiores em $1,4 \mathrm{~mm}$ e entre os segundos molares em 2,33mm; ${ }^{52}$

- protrusão do lábio superior em 0,31mm e do inferior em $0,95 \mathrm{~mm}, 52$

- aumento do trespasse horizontal em $1,3 \mathrm{~mm},{ }^{52}$

- redução do trespasse vertical em $1,39 \mathrm{~mm},{ }^{52}$

- vestibularização dos incisivos superiores em 2,4-5.52

No estudo realizado por GHOSH; NANDA ${ }^{52}$, os autores observaram efeitos esqueléticos promovidos pelo aparelho Pendulum. $O$ maior efeito ocorreu na AFAl que aumentou $2,79 \mathrm{~mm}$ em média e 2 vezes mais em pacientes apresentando FMA $>24^{\circ}$. O plano mandibular inclinou inferiormente em média 1,09을 proporcionando a redução do trespasse vertical $(1,39 \mathrm{~mm})$. Os resultados mostraram que o aparelho Pendulum afeta primariamente os dentes e osso alveolar, embora possua efeitos indiretos nas estruturas esqueléticas e tecidos moles. Contrariamente, BYLOFF; DARENDELILER $^{30}$ não determinaram qualquer efeito esquelético ocasionado pelo aparelho, sem a ocorrência de mordida aberta dentária ou esquelética.

Mais recentemente, outros autores investigaram os efeitos provocados pelo tratamento com o aparelho Pendulum. BUSSICK; Mc NAMARA JUNIOR ${ }^{29}$, em 2000, examinaram as alterações dentoesqueléticas ocasionadas pelo Pendulum em 101 pacientes, com idade média de 12 anos. Os indivíduos foram tratados por 13 diferentes profissionais, sendo que as molas foram ativadas 60 a 90, produzindo uma força para distal de 200 a $250 \mathrm{~g}$. As consultas de monitoramento foram mensais, num período de 8 a 12 semanas. As telerradiografias finais foram obtidas quando os molares atingiram a relação molar próxima de Classe III. Os autores atentaram para a presença ou ausência dos segundos molares decíduos e dos segundos molares irrompidos, além dos diferentes padrões faciais, caracterizados pelo FMA, considerado baixo quando $<$ que $21^{\circ}$, alto se $>$ que $26^{\circ}$ e neutro entre 
$21^{\circ}$ e $26^{\circ}$. Os resultados indicaram que 0 aparelho Pendulum afeta primariamente o arco dentário superior, com efeitos menos pronunciados sobre as estruturas esqueléticas craniofaciais e tecidos moles. A distalização média dos primeiros molares superiores consistiu em $5,7 \mathrm{~mm}$, com uma inclinação distal de $10,6^{\circ}$. Os dentes da unidade de ancoragem sofreram mesialização de $1,8 \mathrm{~mm}$, sendo que os pré-molares apresentaram inclinação mesial de 1,50. O espaço obtido deveu-se à distalização dos molares em $76 \%$ e em $24 \%$, devido à mesialização dos pré-molares. A relação molar demonstrou 6,4mm de correção da Classe II para a Classe I. Os primeiros molares superiores intruíram $0,7 \mathrm{~mm}$, enquanto que os primeiros pré-molares extruíram $1 \mathrm{~mm}$. Os primeiros molares inferiores extruíram 0,7mm, com mesialização de $0,2 \mathrm{~mm}$. As alterações verticais mostraram que o plano palatino permaneceu inalterado durante o período. O ângulo do plano mandibular e a AFAl aumentaram significantemente. A mandíbula apresentou rotação horária de $1^{\circ}$, a sobremordida profunda diminuiu $1,7 \mathrm{~mm}$ e a sobressaliência aumentou 0,8mm. A AFAl aumentou 2,2mm e não houve diferença entre os pacientes com FMA baixo, alto ou neutro. Atribuiurse esse aumento à extrusão de $0,7 \mathrm{~mm}$ dos molares inferiores associado ao movimento para distal dos molares superiores para dentro do arco de fechamento. Considerando-se a ancoragem proporcionada pelos molares decíduos em relação aos pré-molares, ocorreu uma extrusão maior no último grupo, produzindo maior aumento da AFAI (2,4mm contra 1,6mm). Não houve diferença na quantidade de distalização na presença ou ausência dos segundos molares superiores irrompidos, exceto relacionada a um maior aumento da AFAl, na presença desses. Constatourse a ocorrência da protrusão do lábio superior de $0,6 \mathrm{~mm}$ e do lábio inferior de $1 \mathrm{~mm}$, em relação ao plano estético. O ângulo nasolabial diminuiu 2,5ำ e a inclinação do lábio superior acentuou-se em $2^{\circ}$. Essas alterações foram atribuídas à perda de ancoragem anterior. Os autores afirmaram que o aparelho Pendulum deve ser empregado idealmente na presença dos segundos molares decíduos e na ausência dos segundos molares superiores, para a obtenção da máxima 
distalização dos molares com o mínimo aumento da AFAl, embora não se tenha constatado abertura significante da mordida.

FUZIY ${ }^{49}$, em 2001, avaliou 32 pacientes Classe II, divisão 1, com idade média de 14 anos e 10 meses. Foram analisadas as telerradiografias em norma lateral e em $45^{\circ}$, além dos modelos iniciais e após a distalização promovida pelo aparelho Pendulum. O período médio de tratamento compreendeu 5,85 meses. Os resultados obtidos consistiram em: 1) não houve alterações esqueléticas na maxila e mandíbula, exceto por uma rotação horária mandibular, refletindo no aumento da AFAl; 2) os primeiros molares superiores distalizaram em média $4,83 \mathrm{~mm}$, com uma inclinação distal de 12,66우 ;) os segundos molares superiores distalizaram em média 4,84mm, com inclinação distal média de 16,23우 4) os primeiros pré-molares mesializaram em média $1,87 \mathrm{~mm}$, inclinando mesialmente $2,51^{\circ}$; 5) os incisivos centrais superiores movimentaram-se mesialmente $1,08 \mathrm{~mm}$, inclinando-se para vestibular 3,40; 6) aumento do trespasse horizontal em $1,56 \mathrm{~mm}$; 7) extrusão dos primeiros molares superiores de $1,52 \mathrm{~mm}$, intrusão dos segundos molares superiores de $0,78 \mathrm{~mm}$ e extrusão dos primeiros prémolares superiores de $1,52 \mathrm{~mm}$; 8) redução do trespasse vertical em 1,03mm; 9) expansão transversal dos primeiros molares em $0,71 \mathrm{~mm}$; 10) a taxa de distalização mensal foi de $1,06 \mathrm{~mm}$, sendo que a abertura do espaço correspondeu a 78,72\%, em decorrência da distalização dos molares e $30,72 \%$, devido à mesialização dos pré-molares; 11$)$ alterações no perfil facial, com o aumento do ângulo nasolabial de 1,35ำ e uma protrusão do lábio superior, em relação à linha $E$, de $0,29 \mathrm{~mm}$. Como forma de controlar a inclinação dos molares superiores, o autor sugere a realização de dobras de anti-inclinação associada à obtenção da sobrecorreção.

Também em 2001, CHAQUÉS-ASENSI; KALRA ${ }^{36}$ analisaram os efeitos do aparelho Pendulum no complexo dentofacial em 26 pacientes, com idade média de 11 anos e 2 meses, possuindo no mínimo uma relação molar de $1 / 2$ Classe II, sendo que em 11 pacientes os segundos molares superiores não haviam irrompido. Os primeiros molares distalizaram 5,3mm, 
inclinaram para distal $13,1^{\circ}$ e intruíram 1,2mm. Os primeiros pré-molares superiores ou primeiros molares decíduos mesializaram 2,2mm, inclinaram para mesial 4,8 e extruíram $1,2 \mathrm{~mm}$. Os incisivos centrais superiores protruíram $2,1 \mathrm{~mm}$ e sua inclinação aumentou $5,1^{\circ}$ para vestibular. $O$ trespasse horizontal aumentou $1,8 \mathrm{~mm}$ e o vertical diminuiu $1,8 \mathrm{~mm}$. A altura facial ântero-inferior aumentou $2,8 \mathrm{~mm}$, enquanto que o FMA aumentou 1,3 . O tempo médio de distalização compreendeu 6,5 meses, em uma proporção de $0,8 \mathrm{~mm} / \mathrm{mês}$. A quantidade de distalização apresentourse independente da presença ou não dos segundos molares superiores, mas a perda de ancoragem caracterizou-se maior em $0,5 \mathrm{~mm}$ com a irrupção dos segundos molares. Os autores contra-indicaram o uso do aparelho Pendulum em pacientes com altura facial ântero-inferior excessiva e/ou mordida aberta.

\section{Modificações do aparelho Pendulum:}

Visando a minimizar ou corrigir a inclinação distal dos molares distalizados com 0 aparelho Pendulum, alguns autores ${ }^{31,117}$ propuseram modificações na estrutura do aparelho.

Nos casos apresentando severa constricção maxilar, SNODGRASS ${ }^{122}$, em 1996, sugere a incorporação de um parafuso expansor de $11 \mathrm{~mm}$ no Botão de Nance, soldado mesialmente aos tubos molares por lingual, de maneira a fornecer maior rigidez à expansão maxilar. Em decorrência disso, realiza-se a expansão maxilar previamente à distalização dos molares superiores. O parafuso é ativado 2 vezes ao dia, por aproximadamente 2 semanas, até a sobrecorreção da mordida cruzada posterior. $\mathrm{O}$ aparelho deve ser mantido por pelo menos 1 mês até que as molas do aparelho Pendulum sejam ativadas. Ativam-se as molas por meio do corte da união do parafuso expansor com o primeiro molar superior, realizado com uma broca 557 . Em alguns casos, a reativação das molas intrabucalmente torna-se necessária. A maior vantagem apresentada por esse aparelho consiste na redução do tempo de tratamento, sem a 
necessidade da instalação de dois aparelhos subseqüentemente (o expansor maxilar e o aparelho Pendulum).

Já MARTINS; MELO; MARTINS ${ }^{92}$, também em 1996, propuseram a extensão do grampo de apoio dos pré-molares até os caninos, possibilitando o corte do braço de extensão de ambos os pré-molares na fase de contenção, de maneira a permitir a movimentação espontânea desses dentes para distal, finda a distalização dos primeiros molares superiores por meio do aparelho Pendulum. Além disso, os autores sugeriram que a distalização dos segundos molares superiores seja realizada anteriormente aos primeiros molares, sendo estabilizada $œ m$ fio de aço inoxidável incorporado à resina acrílica do Botão de Nance até a posterior distalização do primeiro molar superior.

Outras modificações foram propostas na literatura. BYLOFF et al. ${ }^{31}$, em 1997, sugeriram a confecção de uma dobra de verticalização de $10^{\circ}$ a 15으, em relação ao plano sagital mediano, entre o braço longo da mola e a extremidade final que se insere no tubo lingual do molar, utilizando um alicate Weingart. A dobra deve ser realizada após a distalização dos molares até a relação molar de Classe I sobrecorrigida. O período de verticalização dos molares compreende, em média, 10 semanas, levando a um aumento no tempo total de tratamento de $64,1 \%$. Os resultados mostraram que houve maior movimento de corpo do molar após o período de verticalização, com redução da inclinação distal final de $14,5^{\circ}$ para $6,07^{\circ}$. Primeiramente, ocorreu inclinação dos molares para distal com a posterior verticalização, semelhantemente à técnica de Begg e a filosofia mais recente Tip-Edge. Durante a fase de verticalização, a média mensal da distalização dos ápices dos molares compreendeu $1,01 \mathrm{~mm}$, com desvio padrão de $0,57 \mathrm{~mm}$. Observou-se suave aumento da perda de ancoragem em $0,61 \mathrm{~mm}$ dos prémolares e $0,62 \mathrm{~mm}$ dos incisivos, talvez devido ao tratamento mais longo. Os autores apontam como alternativa para evitar a maior perda de ancoragem e o aumento no tempo de tratamento, a realização da dobra de verticalização 
desde o início da terapia, para que a verticalização do molar superior ocorra simultaneamente à distalização.

De acordo com SCUZZO; PISANI; TAKEMOTO ${ }^{117}$, em 1999, a inversão da alça horizontal da mola TMA do aparelho Pendulum promove o movimento de corpo dos molares superiores. Uma vez que o movimento para distal tenha ocorrido, ativa-se a alça simplesmente por sua abertura. A ativação produz verticalização vestibular e/ou distal das raízes dos molares, resultando em movimento de corpo. Essa modificação recebeu o nome de "M-Pendulum". Os autores verificaram o movimento de corpo com o uso deste sistema por meio de radiografias periapicais iniciais e finais e concluíram que o M-Pendulum constituiu-se em um meio efetivo de distalização dos molares, com a obtenção do movimento de corpo, de fácil construção, aceitação do paciente e com necessidade de reduzidas reativações.

\section{Contenção:}

HILGERS $^{70}$, em 1992, propôs quatro formas para a estabilização dos molares distalizados:

1) instalação do aparelho ortodôntico fixo conjuntamente a um arco utilidade superior que contém os molares em suas posições utilizando os incisivos superiores como ancoragem. Os pré-molares são retraídos com o uso de cadeias elastoméricas.

2) Inserção de um Botão de Nance confeccionado durante a consulta de remoção do aparelho Pendulum. De acordo com o autor, essa consiste na forma mais estável e confiável de contenção dos molares superiores.

3) Instalação do aparelho ortodôntico fixo associado a um arco com ômega por mesial ao primeiro molar superior. Recomendou ainda a associação de um Botão de Nance. 
4) Uso do AEB por poucos meses até a distalização completa dos prémolares e caninos. Embora requerida a colaboração do paciente, essa compreende um curto período de tempo.

Posteriormente, RONDEAU ${ }^{113}$, em 1995, revisando a literatura, sugeriu outros meios de contenção. $O$ aparelho Pendulum pode ser modificado em um aparelho de contenção pelo corte da extensão da porção de resina acrílica ao primeiro pré-molar e pela desativação das molas TMA. Outra forma constitui-se na combinação da barra transpalatina ao Botão de Nance, proporcionando ancoragem adequada para a retração dos prémolares e caninos, ou mesmo a utilização do aparelho Rick-A-Nator que consiste em um Botão de Nance modificado, em que a região anterior de acrílico constitui-se em um plano de mordida anterior, desocluindo os dentes posteriores. É indicado nos casos onde há sobremordida profunda e os incisivos apresentam-se lingualizados.

Contudo, observa-se que a contenção mais utilizada pela maioria dos autores é o Botão de Nance ${ }^{30}, 31,49,70,76,87,104,117,118,119,122$. Além disso, verifica-se na literatura que o uso do AEB noturno colabora na contenção dos molares distalizados e proporciona a verticalização das suas raízes. 33, 34, 36, 47, 57, 67, 90,104, 115, 123 
PROPOSIÇÃO 


\section{PROPOSIÇÃO}

Este estudo visa a analisar cefalometricamente, em telerradiografias em norma lateral, as possíveis alterações craniofaciais pósdistalização dos molares superiores por meio do aparelho Pendulum, em jovens brasileiros, leucodermas, no período compreendido entre a remoção do aparelho distalizador e o término do alinhamento e nivelamento do arco dentário superior, com a finalidade de:

1) Avaliar os efeitos esqueléticos após o uso do aparelho Pendulum durante o tratamento ortodôntico fixo associado ao aparelho extrabucal de tração cervical, de uso noturno;

2) Verificar as alterações nos primeiros molares, primeiros prémolares e incisivos superiores promovidas durante a terapia ortodôntica fixa, subseqüente à distalização dos molares superiores realizada por meio do aparelho Pendulum;

3) Determinar as alterações tegumentares no perfil facial;

4) Avaliar se os efeitos adversos promovidos pelo aparelho Pendulum, durante a distalização dos molares superiores, serão corrigidos com a instalação do aparelho ortodôntico fixo e aparelho extrabucal, de uso noturno. 
MATERIAL E MÉTODOS 


\section{MATERIAL E MÉTODOS}

\section{1 - MATERIAL:}

A amostra utilizada neste estudo consistiu de vinte e três indivíduos, de ambos os gêneros (7 do gênero masculino e 16 do feminino), leucodermas, brasileiros, naturais da cidade de Bauru, Estado de São Paulo, com a idade cronológica variando de 12 anos e 3 meses a 18 anos e 1 mês, idade média de 15 anos e 1 mês.

Os pacientes foram selecionados a partir de uma amostra submetida ao tratamento distalizador com o aparelho Pendulum (figuras $1 \mathrm{e}$ 2), tratada por um mesmo operador, aluno do curso de Pós-graduação em Ortodontia, em nível de Doutorado, obedecendo os seguintes critérios:

1) Todos os pacientes foram submetidos à distalização de molares superiores para a correção da relação molar de Classe II, por meio do aparelho Pendulum, realizada na Clínica de Ortodontia da Faculdade de Odontologia de Bauru da Universidade de São Paulo. (figuras 3 e 4) Desses pacientes, 22 indivíduos possuíam Classe II, divisão 1, sendo que apenas 1, possuía Classe II, divisão 2;

2) Relação molar de Classe I, envolvendo a sobrecorreção de aproximadamente $2,0 \mathrm{~mm}$;

3) Presença de todos os elementos dentários permanentes, exceto os terceiros molares.

Vale ressaltar que, nessa seleção, não foi incluído nenhum critério de avaliação esquelética, somente se verificou previamente ao tratamento distalizador uma relação de molares e de caninos de Classe II, posteriormente corrigida (a relação molar) com o uso do aparelho "Pendulum", proposto por HILGERS ${ }^{70}$ para a distalização dos molares superiores, com a liberação de uma força distalizadora de 253,3g/lado, por um período aproximado de 5,85 meses. $^{49}$ 


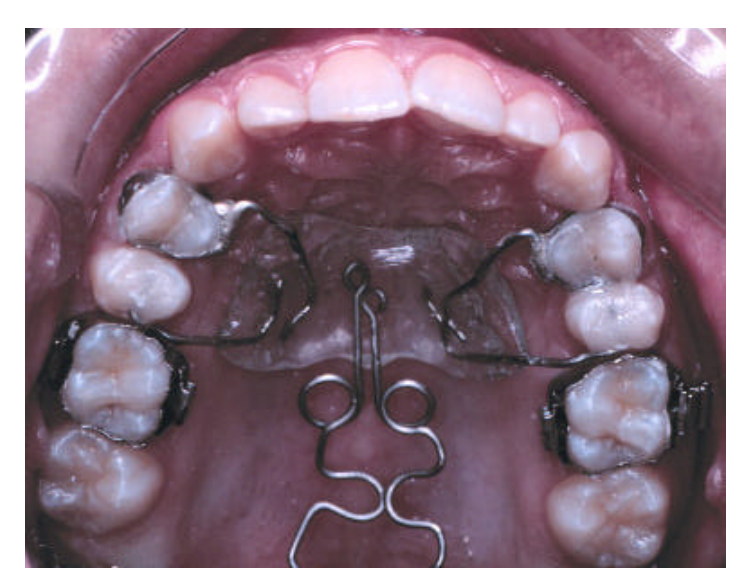

Figura 1 - Aparelho Pendulum demonstrando a pré-ativação das molas TMA, preconizada por HILGERS ${ }^{70}$, utilizada durante a distalização dos molares superiores

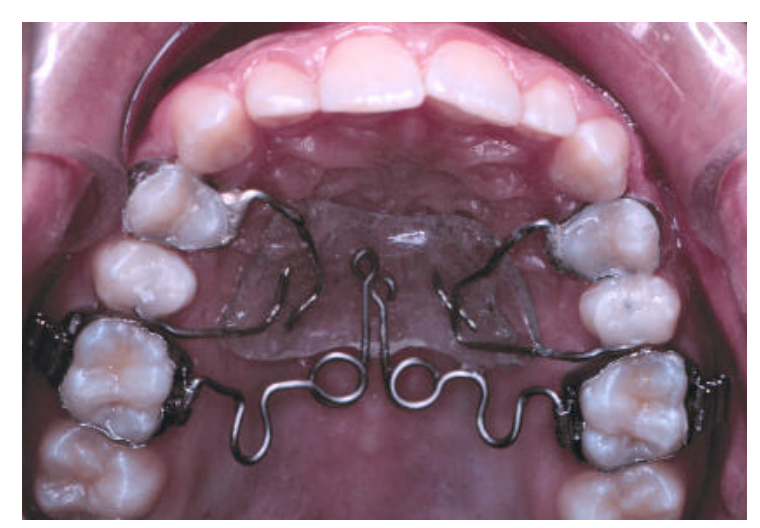

Figura 2 - Aparelho Pendulum instalado, com as molas TMA préativadas em posição. 

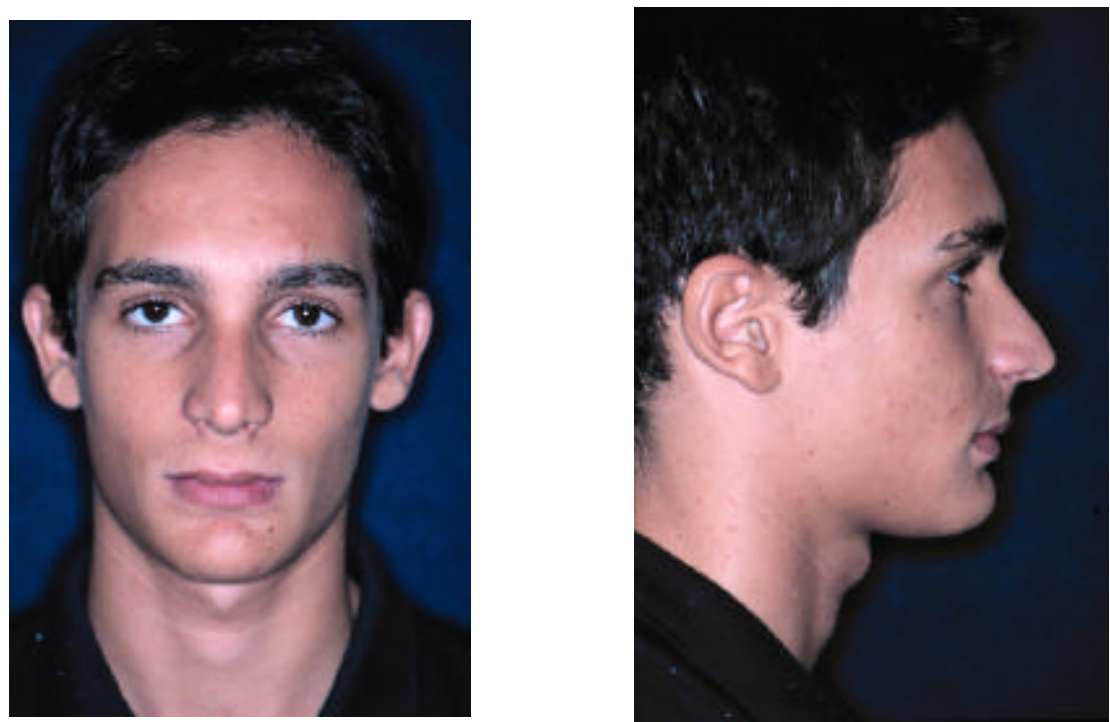

Figura 3 - Aspecto extrabucal de um paciente da amostra logo após a remoção do aparelho Pendulum
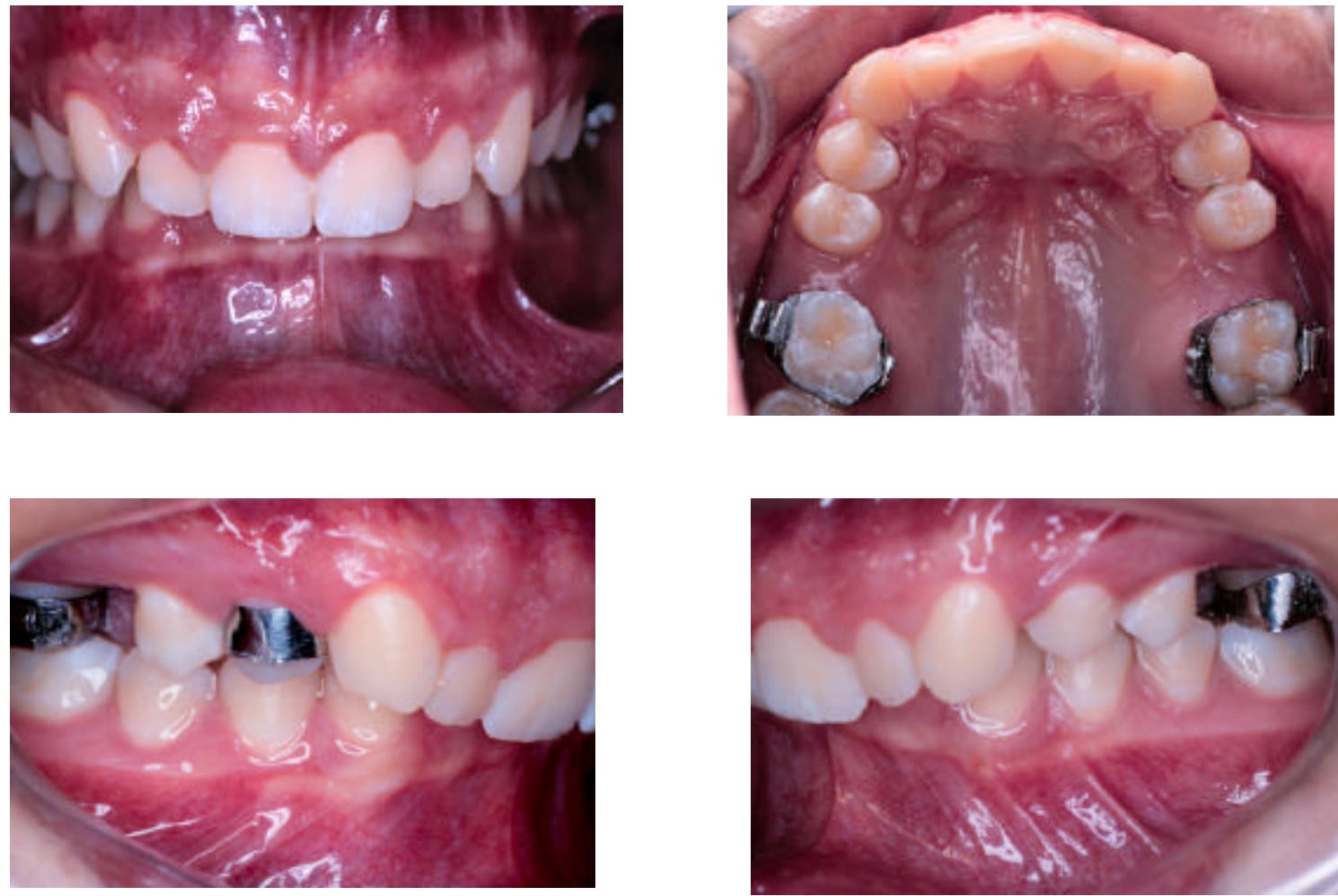

Figura 4 - Vista intrabucal do mesmo paciente na remoção do aparelho Pendulum 
Com o intuito de avaliar possíveis alterações nas estruturas ósseas adjacentes, perfil mole, primeiros molares, primeiros pré-molares e incisivos superiores, em decorrência da instalação do aparelho ortodôntico fixo e AEB, de uso noturno, foram analisadas telerradiografias em norma lateral obtidas imediatamente após a obtenção da distalização necessária dos molares superiores com o aparelho Pendulum (quando da sua remoção) e finalizada a fase de alinhamento e nivelamento no arco dentário superior, no fio retangular passivo.

\section{2 - MÉTODOS:}

Os métodos foram divididos didaticamente em:

4.2.1) Tratamento ortodôntico;

4.2.2) Obtenção das telerradiografias em norma lateral;

4.2.3) Elaboração do cefalograma;

4.2.4) Controle do erro;

4.2.5) Análise estatística.

\subsection{1) TRATAMENTO ORTODÔNTICO:}

Obtida a relação molar de Classe I sobrecorrigida em aproximadamente $2 \mathrm{~mm}$, realizou-se a remoção do aparelho "Pendulum". A seguir, foi instalado um Botão Palatino de Nance (figura 5), com a finalidade de contenção da tendência à recidiva dos molares distalizados, confeccionado a partir da moldagem do arco dentário superior. 


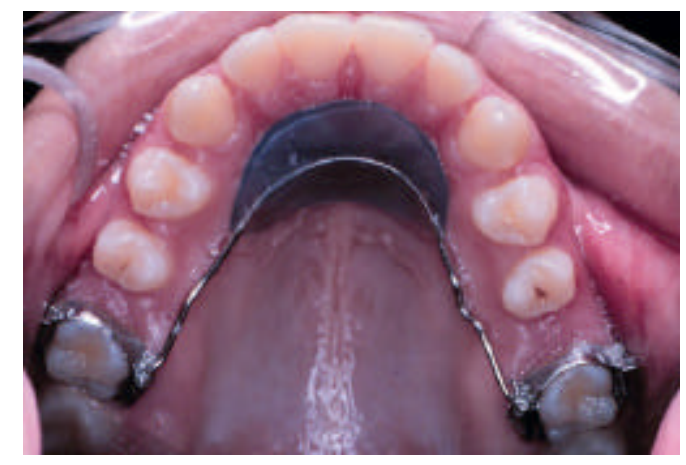

Figura 5 - Botão de Nance instalado imediatamente após a remoção de um aparelho Pendulum

Para maior facilidade e versatilidade da sua utilização durante o tratamento, esse aparelho bi construído adaptando-se o fio que emerge do botão acrílico palatino ao tubo lingual dos primeiros molares superiores, outrora utilizado para inserção das molas distalizadoras do aparelho Pendulum. Esse sistema foi estabilizado com um fio de amarrilho, de maneira a prender firmemente $o$ aparelho de Nance às bandas dos primeiros molares superiores. Esse aparelho foi instalado no mesmo dia da remoção do aparelho Pendulum, sendo que, no período decorrido da remoção do aparelho distalizador até a confecção laboratorial do Botão Palatino de Nance, utilizourse como contenção um botão de resina acrílica realizado individualmente na própria cavidade bucal do paciente. Além disso, adaptouse um aparelho extrabucal (AEB), tração cervical (KHG), com intensidade de força de 400 a $500 \mathrm{~g} / \mathrm{lado}$, somente para uso noturno, de maneira a cooperar na manutenção do espaço obtido na distalização e proporcionar a

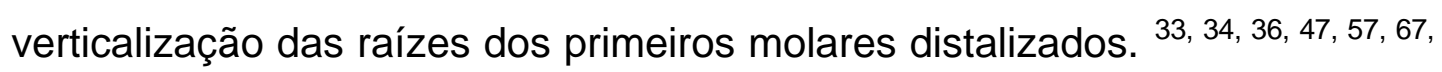
$90,104,115,123$

Após trinta dias, seguiu-se a montagem do aparelho ortodôntico fixo com acessórios da marca ABZIL, prescrição ROTH e ranhura 0.022" $x$ 0.028" (figura 6), iniciando-se a seqüência de fios para alinhamento e nivelamento, que se segue: 
1) Níquel-titânio $0.016 "$

2) Aço inoxidável 0.018"

3) Aço inoxidável $0.020 "$

4) Arco retangular passivo $0.019 "$ x 0.025 ".
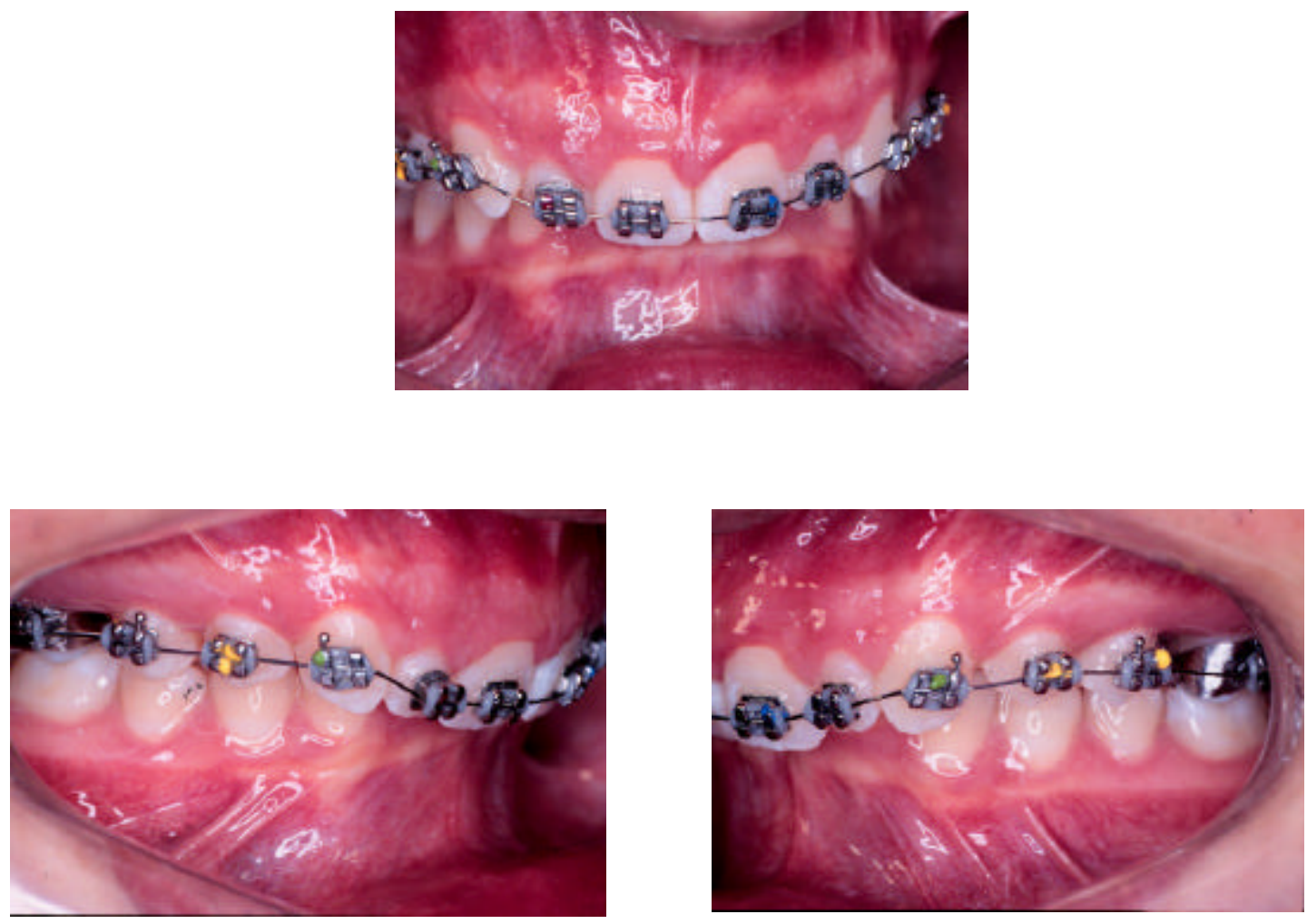

Figura 6 - Aspecto intrabucal do paciente previamente citado na instalação do aparelho ortodôntico fixo

Em muitos pacientes, devido a um apinhamento ânterosuperior mais severo, acentuado ainda pela perda de ancoragem ocorrida durante o tratamento com o aparelho "Pendulum", houve a necessidade do emprego inicial do fio 0.014" níquel-titânio, o que demandou maior tempo para o alinhamento e nivelamento dentários. Além disso, ocorrências clínicas 
como caninos superiores em infravestibuloversão e a grande variação da severidade dos apinhamentos ântero-superiores levaram a uma diversidade no tempo decorrido para a finalização do alinhamento e nivelamento do arco dentário superior.

Quando da instalação do fio retangular superior passivo (0.019" x 0.025") (figura 7), solicitou-se nova telerradiografia em norma lateral para avaliação neste estudo, num período médio de 1 ano entre as duas telerradiografias analisadas. A partir disso, o tatamento ortodôntico seguiu de maneira convencional, passando-se para a distalização dos prémolares superiores realizada um a um (quando essa não ocorreu espontaneamente, devido à ação das fibras transeptais - figuras 8 e 9) , retração ântero-superior (caninos e incisivos superiores), arcos ideais, intercuspidação e finalização. 

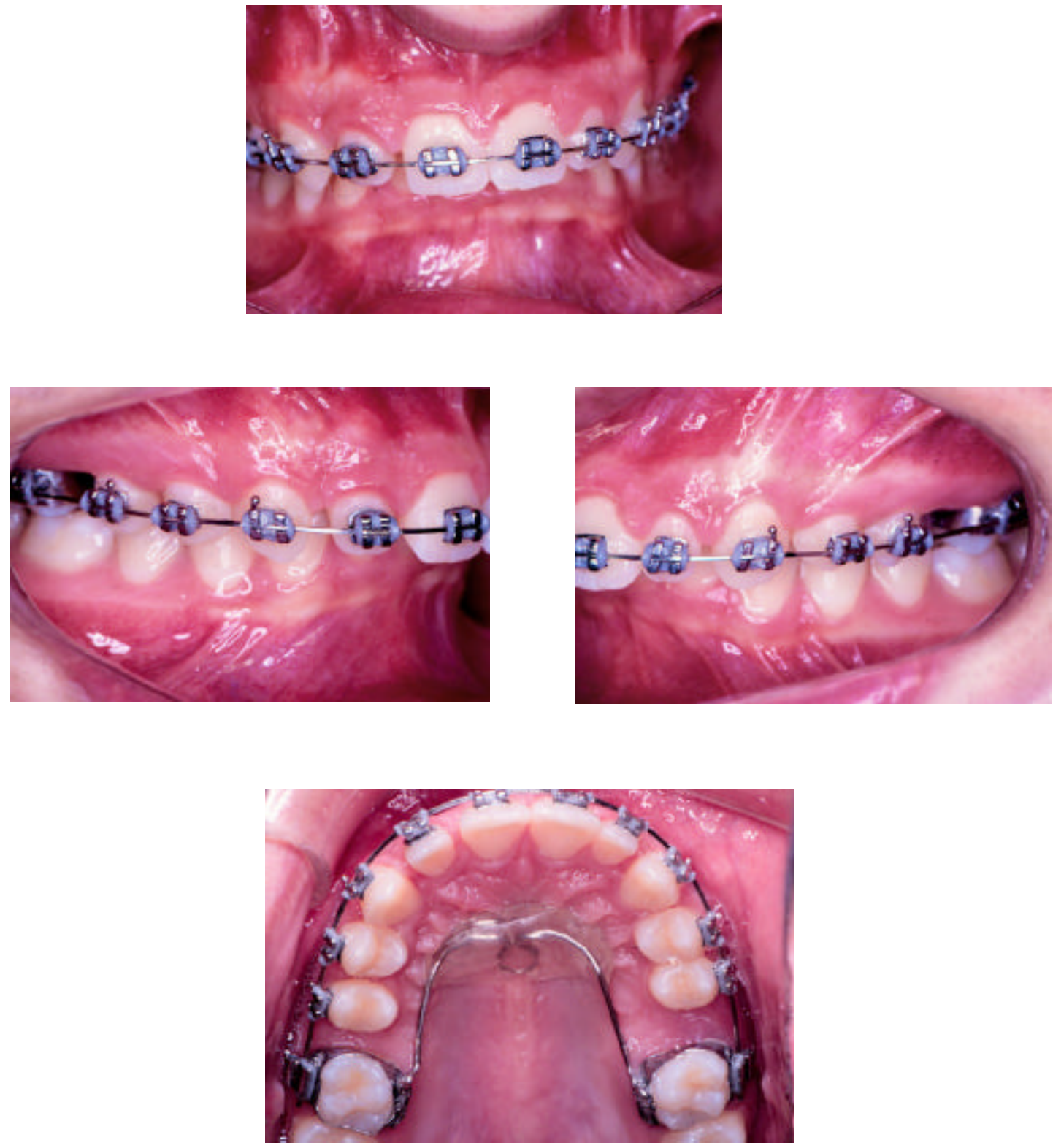

Figura 7 - Aspecto intrabucal do paciente anterior na instalação do fio retangular superior passivo (os pré-molares superiores distalizaram parcialmente) 

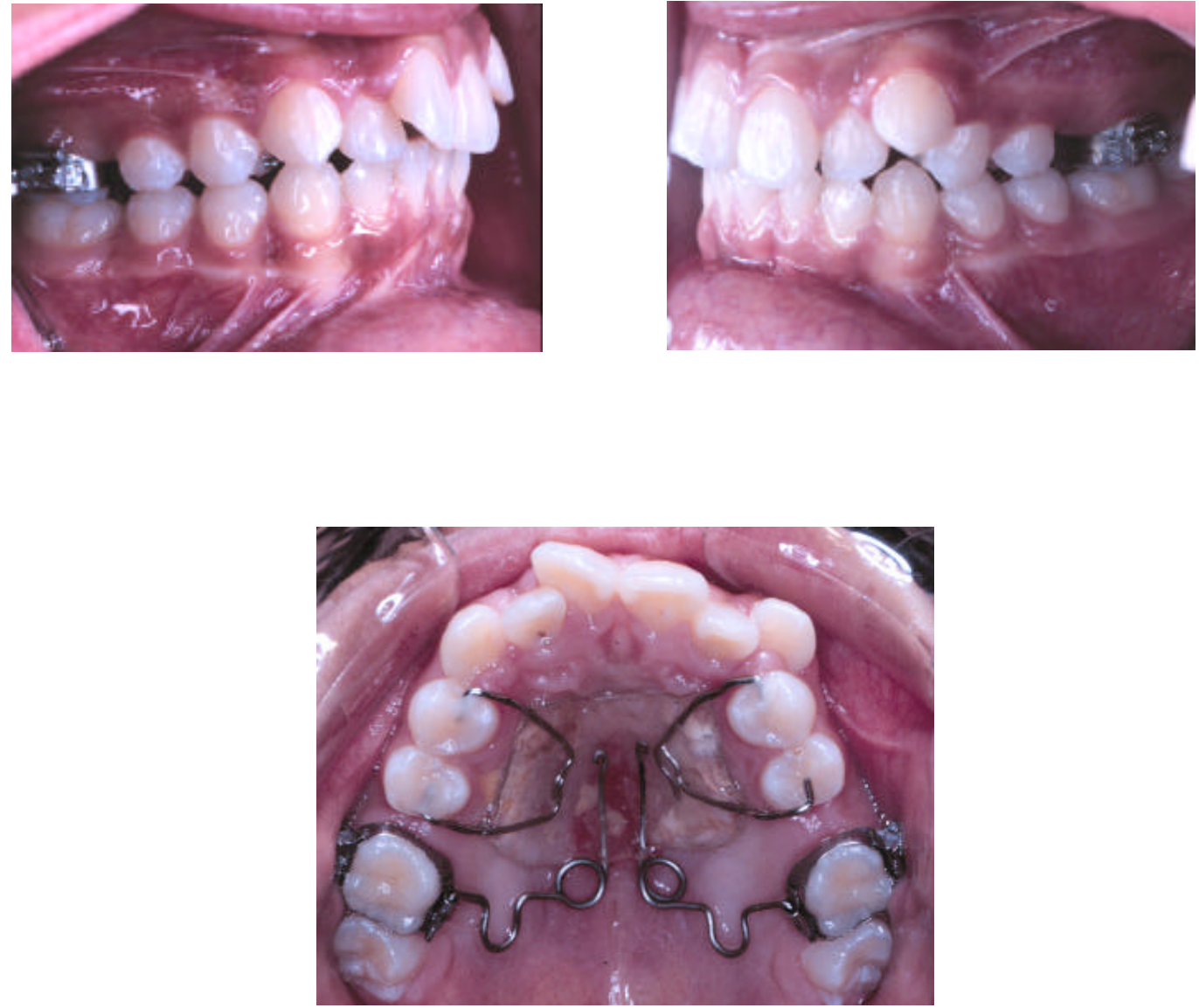

Figura 8 - Aspecto intrabucal de outro paciente da amostra na fase pós-distalização dos molares superiores por meio do aparelho Pendulum 

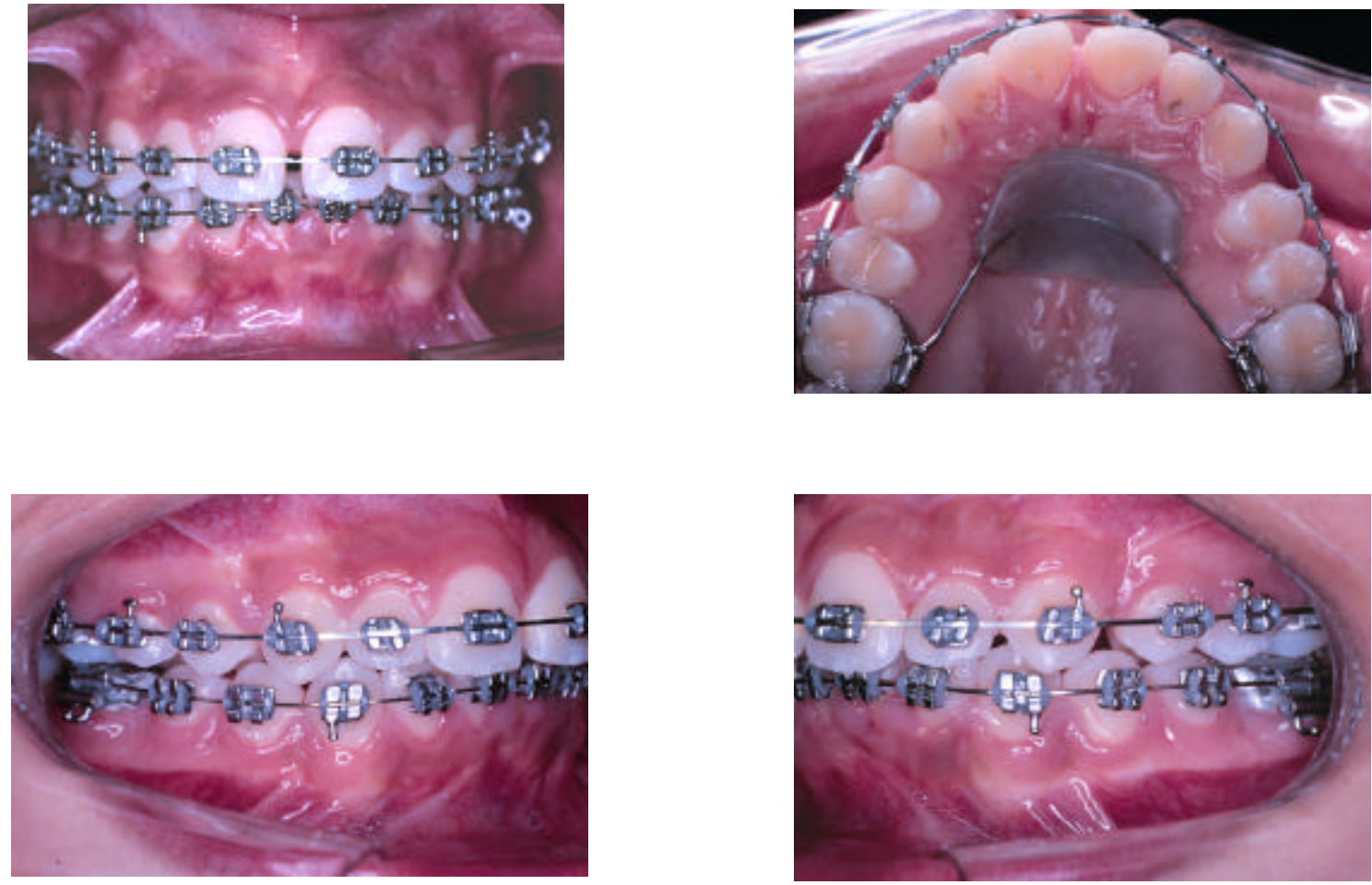

Figura 9 - Vista intrabucal do paciente anterior no término do alinhamento e nivelamento do arco dentário superior. Observe que houve a distalização espontânea dos pré-molares superiores.

\subsection{2) OBTENÇÃO DAS TELERRADIOGRAFIAS EM NORMA LATERAL:}

As telerradiografias em norma lateral foram realizadas no Centro de Diagnóstico Bucal, localizado em Bauru - SP, por um técnico em Radiologia especialmente treinado para a realização dessa técnica radiográfica.

Para isso, foram utilizados filmes extrabucais T-MAT G, de dimensão 18 x 24cm, da marca Kodak e chassi de metal, tamanho 20,8 x $26,8 \mathrm{~cm}$, equipado com ecran intensificador Lanex Regular.

A fonte de raio $x$ empregada consistiu no aparelho Orthophos $C D$, marca comercial SIEMENS, destinado para a realização de 
telerradiografias e radiografias panorâmicas. Os fatores de exposição utilizados constituíram em 73KV, $15 \mathrm{~mA}$ e tempo de exposição de 0,64 segundo. A distância foco-filme foi de $1,52 \mathrm{~m}$. A justaposição de um filtro de alumínio de $90 \mathrm{~mm}$ ao chassi permitiu uma visualização bastante satisfatória do perfil mole nas radiografias obtidas.

Para o posicionamento da cabeça dos pacientes durante a tomada radiográfica, empregou-se um cefalostato, de maneira que o chassi foi acoplado paralelamente ao plano sagital mediano, aproximando ao máximo a cabeça do indivíduo ao filme radiográfico, permitindo um maior contato entre o objeto e o filme. Devido a isso e às características inerentes do aparelho, o fator de magnificação obtido apresentou-se relativamente baixo, de $6 \%$. No momento da tomada radiográfica, todos os pacientes foram orientados para permanecerem com os dentes em máxima intercuspidação habitual e com os lábios em posição de repouso.

Cabe ressaltar que houve uma exceção dentre todas as radiografias analisadas neste estudo. Apenas uma telerradiografia em norma lateral foi obtida em outro local, no Departamento de Radiologia da Faculdade de Odontologia da Universidade Sagrado Coração, onde a magnificação obtida consistiu de 7,3\%. Em decorrência disto, todas as radiografias foram comparadas mediante $\mathrm{o}$ fator de magnificação em programa de computador adequado.

A revelação das radiografias ocorreu pelo método de processamento automático, em câmara escura, sob luz de segurança.

As telerradiografias foram obtidas imediatamente após a remoção do aparelho Pendulum (finda a distalização dos molares superiores) e no término da fase de alinhamento e nivelamento do arco dentário superior, no fio retangular passivo, num período médio de 1 ano (figura 10). 

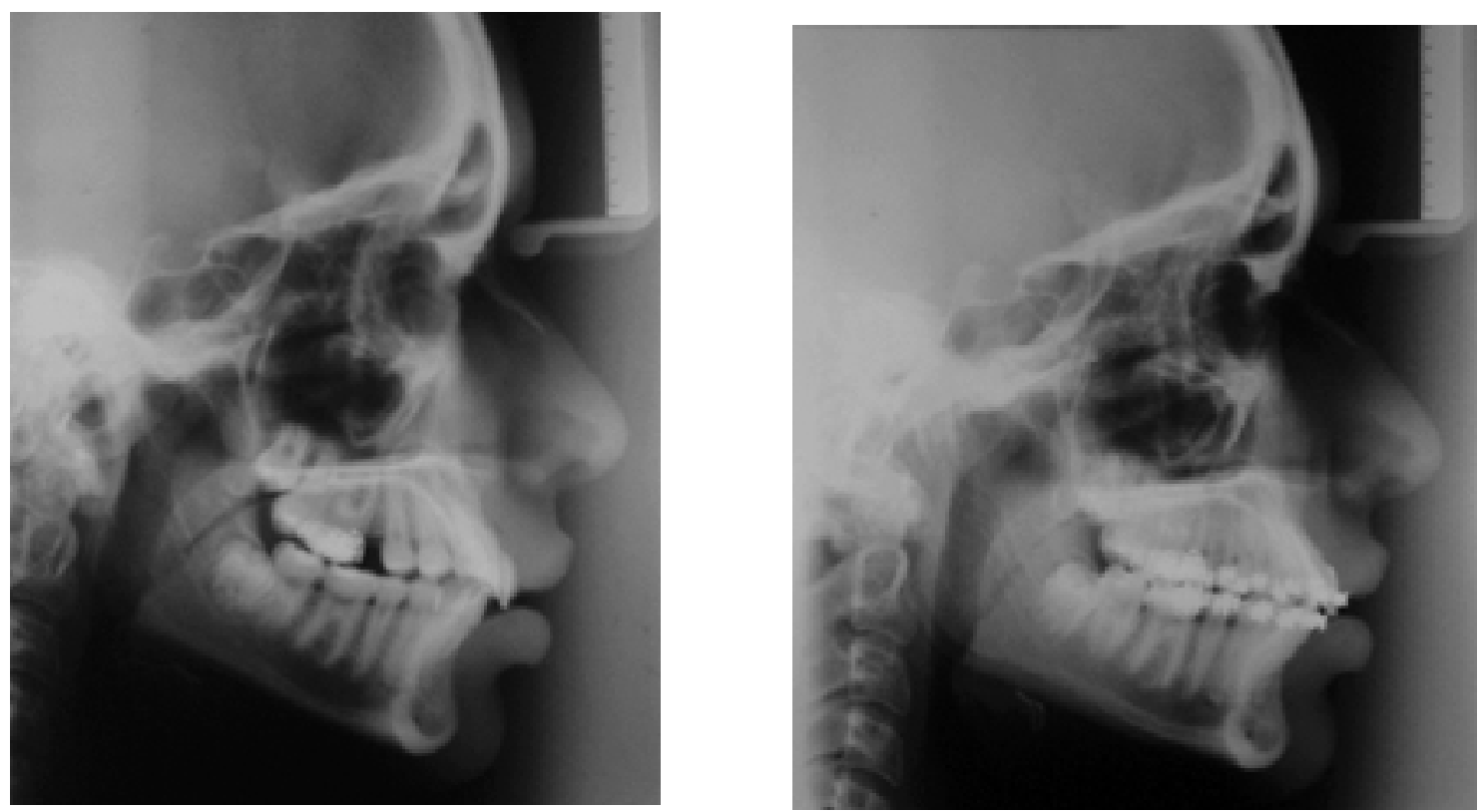

Figura 10 - Telerradiografias em norma lateral tomadas logo após a remoção do aparelho Pendulum e no final do alinhamento/nivelamento do arco dentário superior de um mesmo paciente

\subsection{3) ELABORAÇÃO DO CEFALOGRAMA:}

Em cada telerradiografia, adaptou-se uma folha de papel acetato transparente "Ultraphan", de dimensão $17,5 \times 17,5 \mathrm{~cm}$ e espessura de $0,07 \mathrm{~mm}$. A partir disso, um mesmo operador realizou o desenho anatômico sobre um negatoscópio, utilizando uma lapiseira e grafite HB $0,3 \mathrm{~mm}$. Para facilitar a visualização das estruturas em questão, esse procedimento foi executado em sala obscurecida.

A elaboração do cefalograma consistiu em:

- desenho anatômico;

- definição dos pontos cefalométricos; 
- estabelecimento das linhas e planos;

- método de sobreposição;

- obtenção das medições cefalométricas.

\section{Desenho anatômico:}

O traçado cefalométrico constituiu-se da base do crânio, maxila, mandíbula, órbita, perfil mole, meato acústico externo, osso nasal, osso frontal, fissura pterigopalatina, sela túrcica, primeiros molares, primeiros prémolares e incisivos centrais superiores; traçados de acordo com as normas pré-estabelecidas em Ortodontia. As estruturas simétricas que, portanto, apresentaram imagem duplicada na telerradiografia, foram traçadas a partir da média das mesmas. (figura 11)

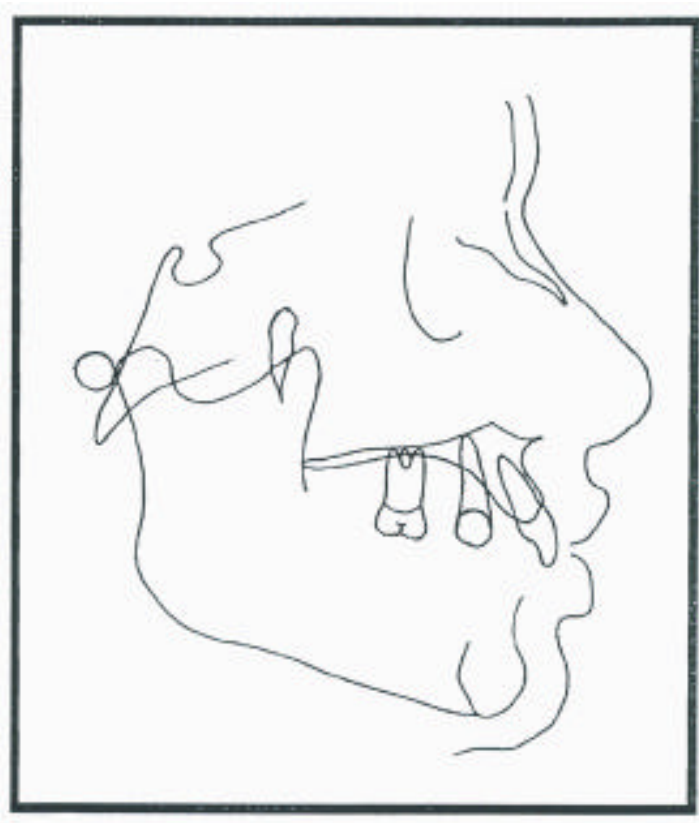

Figura 11 - Desenho anatômico 


\section{Definição dos pontos cefalométricos:}

Os pontos cefalométricos demarcados consistiram em: (figura 12)

- Sela (S): ponto que representa o centro geométrico da sela túrcica, determinado por inspeção visual;

- $\quad$ Násio (N): ponto mais anterior da sutura frontonasal;

- Orbitário (Or): ponto mais inferior da margem infraorbitária;

- Pório (Po): ponto mais superior do meato acústico externo;

- Subespinhal (A): ponto mais profundo da concavidade anterior da maxila;

- Supramentoniano (B): ponto mais profundo na concavidade anterior da mandíbula;

- Ponto D (D): ponto situado no centro do contorno da secção transversal da sínfise mandibular;

- Pogônio (P): ponto mais anterior do contorno da sínfise mandibular;

- Gnátio (Gn): ponto mais inferior e anterior do contorno do mento, definido pela bissetriz do ângulo formado pela linha NP e pelo plano mandibular (GoMe);

- Mentoniano (Me): ponto mais inferior do contorno da sínfise mentoniana;

- Gônio (Go): ponto mais inferior e posterior do contorno do ângulo goníaco, definido pela bissetriz do ângulo formado pela tangente à borda inferior do corpo mandibular e outra tangente à borda posterior do ramo ascendente da mandíbula;

- Espinha nasal anterior (ENA): ponto mais anterior da maxila ao nível do palato;

- Espinha nasal posterior (ENP): ponto mais posterior da maxila ao nivel do palato; 
- Fissura pterigomaxilar (PTM): ponto mais posterior da fissura pterigomaxilar; ${ }^{110}$

- Centro da coroa do primeiro molar superior (CM): ponto médio da linha que une a maior convexidade mesial e distal do primeiro molar superior; 30, 31, 36, 52, 99

- Centro da coroa do primeiro pré-molar superior (CPm): ponto médio da linha que une a maior convexidade mesial e distal do primeiro pré-molar superior; ${ }^{30,31,36,52,99}$

- Ponto incisal (Is): ponto mais incisal do incisivo central superior;

- Ápice radicular do incisivo central superior (AIS): ponto do ápice radicular do incisivo central superior;

- Lábio superior (Ls): ponto na região mais anterior do lábio superior;

- Lábio inferior (Li): ponto localizado na região mais anterior do lábio inferior;

- Pogônio mole $\left(\mathrm{Pg}^{\prime}\right)$ : ponto mais anterior no contorno do mento mole;

- Pronasal (Pr): ponto mais anterior do nariz;

- Columela nasal (Cn): ponto mais inferior da borda inferior do nariz;

- Subnasal (Sn): ponto em que a columela intersecta-se com o lábio superior no plano médio sagital. 


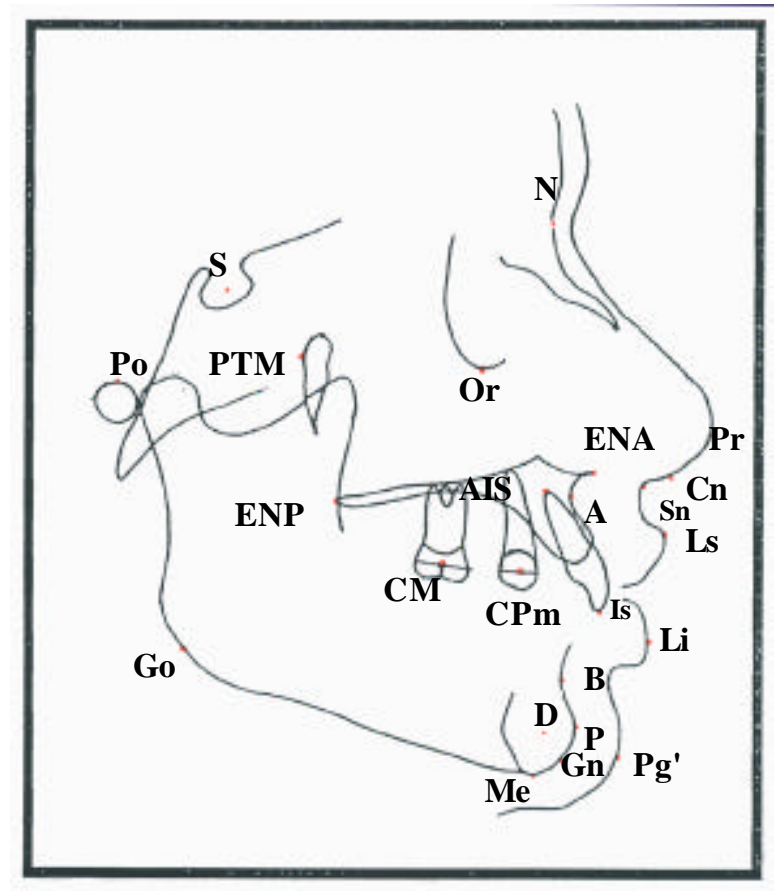

Figura 12 - Pontos Cefalométricos

\section{Estabelecimento das linhas e planos cefalométricos:}

As linhas e planos empregados como referência para as medidas avaliadas foram: (figura 13)

- Plano palatino: linha que passa pelos pontos ENA e ENP;

- Plano mandibular GoGn: linha que une os pontos Go e Gn;

- Plano mandibular GoMe: plano representado por uma linha que passa pelos pontos Go e Me;

- Plano horizontal de Frankfurt: plano que une os pontos Po e Or;

- Linha SN: linha que passa pelos pontos S e N;

- Linha NA: linha que une os pontos N e A;

- Linha NB: linha que se estende do ponto N ao B;

- Linha ND: linha que une os pontos N e D; 
- Linha vertical pterigóide (PTV): linha tangente ao ponto PTM e perpendicular ao plano horizontal de Frankfurt; ${ }^{43,} 110$

- Linha E: linha que une os pontos Pr e Pg';10

- Linha que une os pontos ENA e Me;

- Linha que passa pela columela nasal até o ponto Sn;

- Linha que se estende do ponto subnasal até o ponto Ls;

- Longo eixo do incisivo central superior: linha que passa pelo ápice (AIS) e pelo ponto mais incisal do incisivo central superior (Is);

- Longo eixo do primeiro molar superior: perpendicular à linha que une a maior convexidade mesial e distal do primeiro molar superior, passando pelo ponto do centro da coroa $(\mathrm{CM}) ; 30,31,36,52$, 99

- Longo eixo do primeiro pré-molar superior: perpendicular à linha que une a maior convexidade mesial e distal do primeiro pré-molar superior, no ponto do centro da coroa (CPm); ${ }^{30,31,36,52,99}$

- Linha SGn ( Eixo Y de Crescimento): linha que une os pontos S e Gn; 


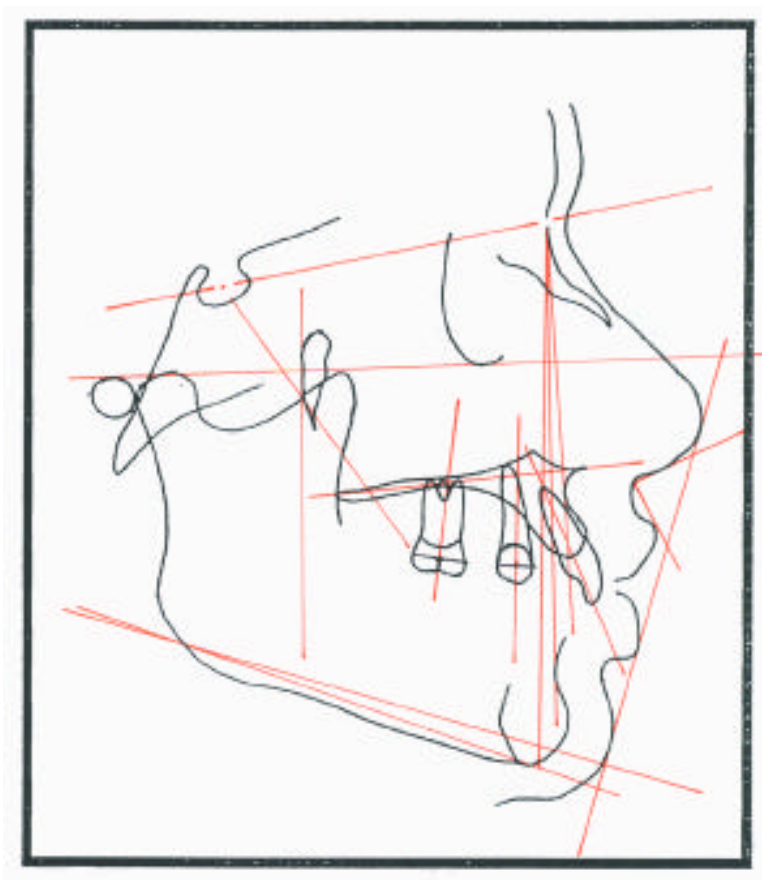

Figura 13 - Linhas e Planos

\section{Método de sobreposição:}

Para assegurar maior precisão dos pontos demarcados nas estruturas dentárias, os primeiros molares, primeiros pré-molares e incisivos superiores foram traçados no primeiro cefalograma e transferidos para 0 segundo cefalograma, por meio da cópia em papel acetato tipo "Ultraphan" individual, para que assim fossem eliminadas possíveis variações de um desenho para o outro, principalmente no que tange às dimensões da coroa, já que o ponto cefalométrico utilizado localizava-se no centro da coroa dos primeiros molares e primeiros pré-molares superiores. Dessa forma, a cópia do desenho do elemento dentário realizado no cefalograma inicial foi adaptada à imagem radiográfica do mesmo na telerradiografia pósalinhamento e nivelamento (segunda telerradiografia avaliada), para se esboçar o posicinamento final do elemento dentário, respeitando-se o seu contorno inicial. 
O mesmo procedimento foi realizado para o traçado da fissura pterigomaxilar, quando a mesma apresentava imagem duplicada, devido à sobreposição das estruturas. Para isso, utilizourse como parâmetro a sobreposição sobre a linha $\mathrm{SN}$, no ponto $\mathrm{S}$, mais próximo da fissura pterigomaxilar e menos susceptível a variações, já que se localiza na base do crânio.

\section{Obtenção das medicões cefalométricas:}

Para a realização das medições cefalométricas, utilizou-se um computador IBM - PC, processador Pentium, em que o programa Dentofacial Planner $7.0^{*}$ foi adaptado por meio de uma análise especialmente confeccionada para a digitalização dos pontos cefalométricos deste estudo. Os procedimentos de digitalização foram executados sempre pelo mesmo operador, que se encontrava adequadamente em posição ereta para a visualização perfeita dos pontos cefalométricos. A digitalização dos mesmos se deu com o auxílio de uma mesa digitalizadora da marca Numonics Accugrid XNT ${ }^{* *}$, modelo 2200, com resolução de cem linhas e precisão de $0,1 \mathrm{~mm}$.

O computador realizou a leitura dos pontos identificados e calculou as medidas cefalométricas angulares e lineares que demonstraram as possíveis alterações esqueléticas, dentárias e tegumentares, posteriores à distalização dos molares superiores durante o tratamento com aparelho ortodôntico fixo. Dividiram-se em:

a) Grandezas angulares esqueléticas;

b) Grandezas angulares e lineares do padrão facial;

c) Grandezas dentárias angulares e lineares;

d) Grandezas tegumentares.

* Dentofacial Software Inc. - 100 Simcoe Street Suite 303, Toronto, Canada M5H3G2

** Numonics Corporation - 101 Commerce Drive, Montgomerryville, PA 18963 


\section{a) Grandezas angulares esqueléticas (figura 14)}

As variáveis utilizadas para a verificação das modificações no esqueleto cefálico decorrentes da instalação do aparelho ortodôntico fixo subseqüente ao procedimento distalizador de molares superiores constituíram-se em:

1- Ângulo SNA: avalia a posição ântero-posterior da maxila, expressando o grau de protrusão ou retrusão da maxila em relação à base do crânio.

2- Ângulo SNB: determina a posição ântero-posterior da mandíbula, representada pelo ponto $B$, em relação à base do crânio.

3- Ângulo SND: estabelece o posicionamento ântero-posterior mandibular, representado pelo ponto $D$, em relação à base do crânio.

4- Ângulo ANB: determinado pela diferença matemática entre os ângulos SNA e SNB, revelando a relação ântero-posterior entre a maxila e a mandíbula. Os valores entre 0 e 4,5 indicam uma provável relação de Classe I, enquanto que valores acima de 4,5, um provável relacionamento de Classe II, ao passo que um ANB negativo sinaliza uma Classe III. 


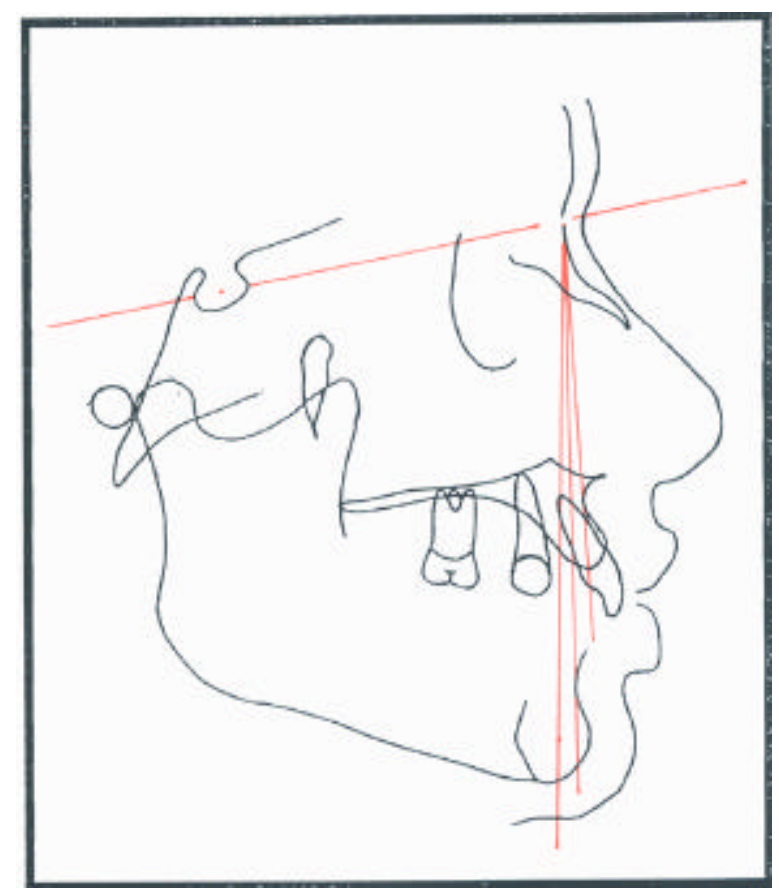

Figura 14 - Grandezas angulares esqueléticas

\section{b) Grandezas angulares e lineares do padrão facial (figura 15)}

1- Altura facial ântero-inferior (AFAI): é a medida linear entre os pontos espinha nasal anterior (ENA) e o mentoniano (Me). Determina o padrão do esqueleto cefálico, se com crescimento preponderante horizontal e/ou vertical, além de identificar uma rotação em sentido horário ou antihorário da mandíbula durante a mecanoterapia.

2- Ângulo SN.GoGn: indica o comportamento da base da mandíbula, representada pelo plano GoGn, em relação à base do crânio (linha SN). Valores acima da norma mostram que há uma divergência dos planos horizontais, com predominância do crescimento craniofacial no sentido vertical. Contudo, valores abaixo da norma determinam um crescimento preponderante no sentido horizontal. 
3- Ângulo FMA: ângulo formado pelos planos horizontais de Frankfurt e mandibular (GoMe). Este ângulo demonstra um crescimento com tendência vertical, se o valor for acima da norma, e horizontal com valores abaixo da norma pré-estabelecida.

4- Ângulo NS.Gn: determinado pelas linhas SN e SGn. É chamado de "eixo $Y$ de crescimento". Define a resultante vetorial de crescimento ântero-inferior da mandíbula. Valores acima da norma representam um vetor de crescimento facial no sentido vertical enquanto que os valores abaixo, um vetor de crescimento facial no sentido horizontal.

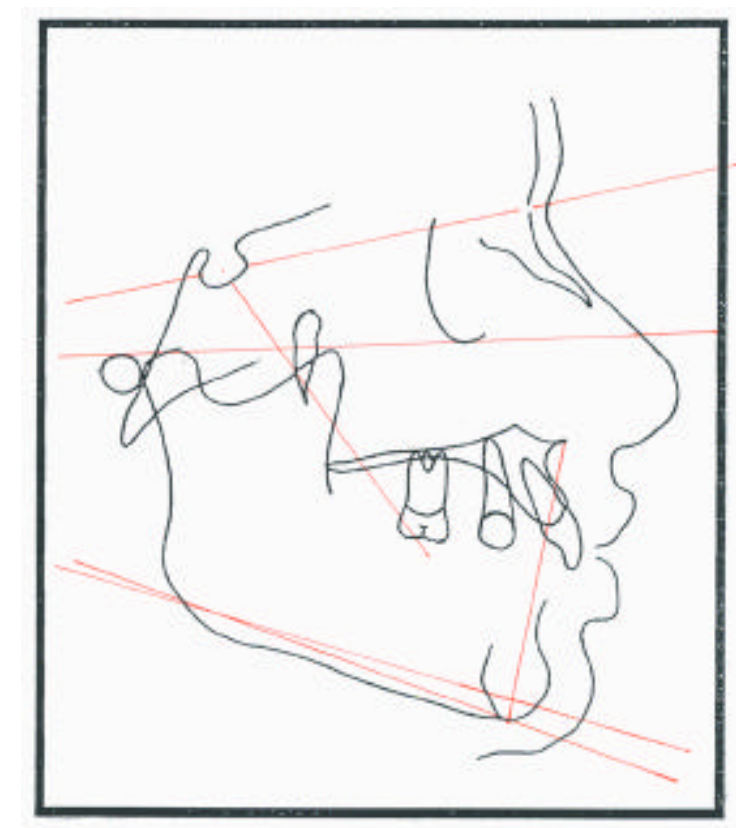

Figura 15 - Grandezas angulares e lineares do padrão facial

\section{c) Grandezas dentárias angulares e lineares (figura 16)}

Com o intuito de melhor avaliar as alterações do primeiro molar, primeiro pré-molar e incisivo central superior, este tópico foi dividido em:

1 - Grandezas dentárias ântero-posteriores; 
2 - Grandezas dentárias verticais;

3 - Grandezas das inclinações dentárias.

\section{1 - Grandezas dentárias ântero-posteriores:}

1- PTV-CM: distância do centro da coroa do primeiro molar superior (CM) à linha vertical pterigóide (PTV). Demonstra a posição ânteroposterior do primeiro molar superior. A interpretação desta grandeza depende da comparação dos valores pós-distalização e pós-nivelamento. Por exemplo, se os valores finais apresentarem-se maiores que os iniciais, houve um movimento para mesial do primeiro molar superior, demonstrando uma provável recidiva;

2- PTV-CPm: distância do centro da coroa do primeiro pré-molar superior $(\mathrm{CPm})$ à linha vertical pterigóide (PTV). Indica a posição ânteroposterior do primeiro pré-molar. É definido pela comparação entre os valores pós-distalização e pós-nivelamento. Valores finais menores que os iniciais demonstram uma distalização espontânea dos pré-molares, já que a retração mecânica desses ainda não foi realizada.

3- PTV-IS: distância do incisivo superior (Is) à linha vertical pterigóide (PTV). Define a posição ântero-posterior do incisivo superior, sendo constituído pela diferença entre os valores obtidos pós-distalização e pós-nivelamento. Valores finais menores que os iniciais indicam uma retrusão do incisivo e valores finais maiores, uma protrusão.

\section{2 - Grandezas dentárias verticais:}

1- PP-IS: distância linear entre o incisivo central superior (Is) e o plano palatino. É definido pela comparação entre os valores pós-distalização e pós-nivelamento. Demonstra se, durante a mecanoterapia, os incisivos sofreram intrusão ou extrusão. 
2- PP-CM: distância linear entre o primeiro molar superior (CM) e o plano palatino. Define se, durante a mecanoterapia, houve intrusão ou extrusão do primeiro molar superior, pela diferença entre os valores obtidos pós-distalização e pós-nivelamento.

3- PP-CPm: distância linear entre o primeiro pré-molar superior $(\mathrm{CPm})$ e o plano palatino. É determinado pela comparação dos valores pósdistalização e pós-nivelamento. Demonstra o grau de intrusão ou extrusão do primeiro pré-molar durante a mecânica empregada.

\section{3 - Grandezas das inclinações dentárias:}

1- PP.CM: ângulo formado pelo longo eixo do primeiro molar superior com o plano palatino. Determinado por comparação entre os valores pós-distalização e pós-nivelamento, indicando se houve verticalização do primeiro molar superior.

2- PP.CPm: ângulo formado pelo longo eixo do primeiro pré-molar superior com o plano palatino. Indica a verticalização do primeiro pré-molar superior se o valor pós-nivelamento for maior que o pós-distalização.

3- PP.IS: ângulo formado pelo longo eixo do incisivo central superior com o plano palatino. Determinado pela comparação dos valores pós-distalização e pós-nivelamento, representando uma inclinação vestibular ou lingual do incisivo superior. 


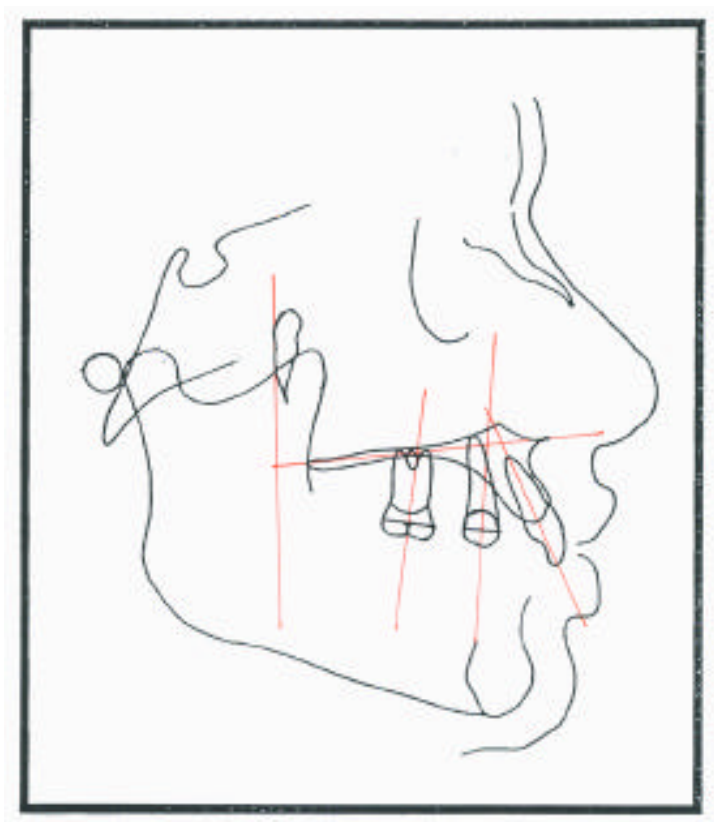

Figura 16: Grandezas dentárias angulares e lineares

\section{d) Grandezas tegumentares: (figura 17)}

1- Ângulo nasolabial: determinado pelo ângulo formado entre a linha que une os pontos subnasal (Sn) e columela nasal (Cn) e outra que se estende do ponto subnasal ao lábio superior (Ls). Um ângulo diminuído representa uma protrusão dentoalveolar superior e aumentado, uma retrusão dentoalveolar superior.

2- E-Li: distância linear entre o lábio inferior $(\mathrm{Li})$ e a linha $\mathrm{E}$. Representa a intercorrência da mecânica no perfil mole do paciente.

3- E-Ls: distância linear entre o lábio superior (Ls) e a linha E. Indica uma protrusão ou retrusão do lábio superior durante a mecânica. 


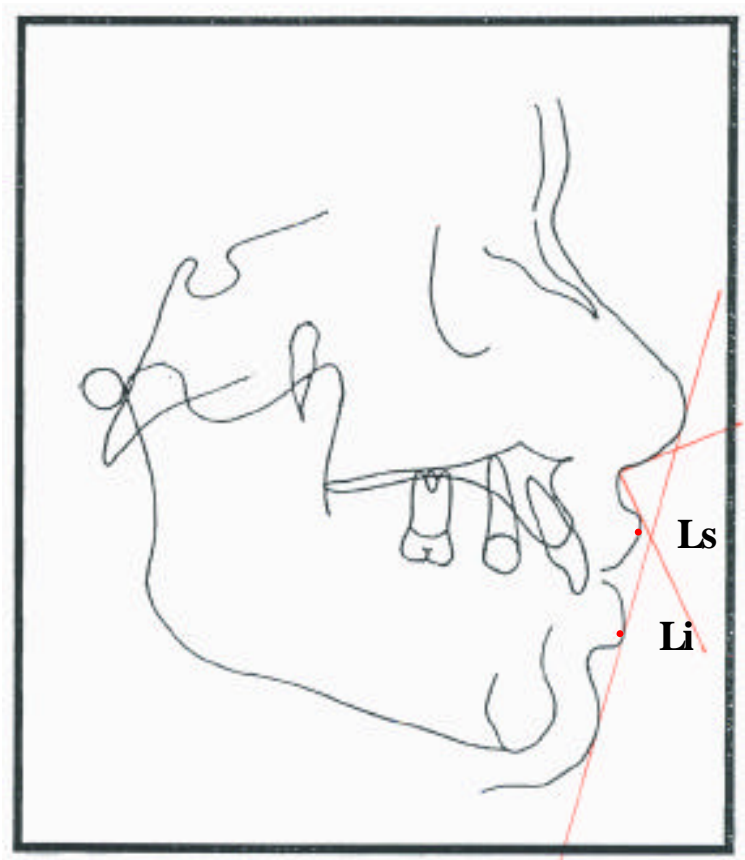

Figura 17 - Grandezas tegumentares

Todas essas medidas foram realizadas nas duas tomadas radiográficas de cada paciente e comparadas entre si.

Os valores obtidos para as medidas angulares e lineares foram dispostos em tabelas no programa Excel e encaminhadas para análise estatística. 


\subsection{4) CONTROLE DO ERRO:}

Inicialmente, os pacientes foram selecionados obedecendo rigorosamente os critérios estabelecidos neste estudo, atentando para o fato de que o procedimento distalizador com o aparelho Pendulum foi realizado somente por um mesmo operador.

Posteriormente, o tratamento ortodôntico com aparelho fixo foi executado apenas por dois profissionais, devidamente calibrados para a realização dos procedimentos de nivelamento e alinhamento dentários obedecendo um mesmo protocolo. Além disto, praticamente quase que a totalidade das tomadas radiográficas foram realizadas num mesmo local, o Centro de Diagnóstico Bucal, utilizando o mesmo aparelho radiográfico e os mesmos métodos de obtenção e revelação das radiografias.

Os cefalogramas foram realizados sempre pelo mesmo operador, utilizando como recurso auxiliar uma sala obscurecida, para visualização mais precisa das estruturas radiográficas.

Em decorrência de todos esses cuidados tomados durante a realização deste estudo, procurou-se uma maior padronização da amostra analisada, minimizando possíveis erros na obtenção dos resultados.

Para avaliação do erro metodológico, casual e sistemático, realizaram-se novamente 20 traçados, selecionados aleatoriamente, ou seja, os cefalogramas iniciais e finais de 10 pacientes, num intervalo de duas semanas entre os traçados. Assim, obtiveram-se dois conjuntos de medidas para os mesmos pacientes, realizados sob as mesmas condições, porém em tempos diferentes. Essas medidas foram comparadas estatisticamente para a verificação da existência de erro significante intra-examinador durante a realização e medição dos cefalogramas. 


\subsection{5) ANÁLISE ESTATÍSTICA:}

Já que os valores obtidos por meio das medições cefalométricas acompanhavam a distribuição normal, representada pela Curva de Gaus, esses foram submetidos ao teste $t$ de Student para dados pareados, por meio do emprego do programa "Statistica for Windows", versão 5.1, produzido por StatSoft Inc. O teste $t$ pareado é o mais indicado para a análise de diferenças ocorridas entre duas ou mais fases do tratamento do mesmo paciente.

Os dados obtidos para todas as medidas cefalométricas relativas às fases pós-Pendulum e pós-nivelamento foram comparadas estatisticamente para a verificação da hipótese de nulidade de que não houve alteração das medidas anteriormente reportadas, em decorrência da mecânica com aparelho ortodôntico fixo e AEB, de uso noturno. O valor crítico foi construído ao nível de significância de 0,05. 
RESULTADOS 


\section{RESULTADOS}

Os efeitos promovidos pela mecanoterapia realizada com 0 aparelho ortodôntico fixo associado ao $\mathrm{AEB}$, de uso noturno, finda a distalização dos molares superiores proporcionada pelo aparelho Pendulum, no esqueleto cefálico, estruturas dentárias e tegumentares, mediante a observação de telerradiografias em norma lateral, constam na tabela a seguir:

TABELA 1: Resultado do teste $t$ de Student para dados pareados

\begin{tabular}{l|c|c|c|c|c|c|c|c} 
& $\mathbf{N}$ & MÉDIA & $\mathbf{D P}$ & $\mathbf{M E ́ D I A}$ & $\mathbf{D P}$ & $\mathbf{D I F}$ & $\mathbf{t}$ & $\mathbf{p}$ \\
& & INICIAL & INICIAL & FINAL & FINAL & & & \\
\hline SNA & 23 & 80,99 & 3,33 & 80,80 & 3,14 & $-0,191$ & $-0,542$ & 0,593 \\
\hline SNB & 23 & 76,22 & 2,77 & 76,53 & 2,80 & 0,317 & 0,901 & 0,377 \\
\hline ANB & 23 & 4,79 & 1,70 & 4,26 & 1,92 & $-0,521$ & $-2,196$ & $0,038^{*}$ \\
\hline E-Li & 23 & $-0,091$ & 3,07 & $-0,004$ & 3,19 & 0,087 & 0,482 & 0,634 \\
\hline NASOL & 23 & 104,03 & 11,57 & 102,18 & 11,92 & $-1,848$ & $-1,647$ & 0,113 \\
\hline SN.GoGn & 23 & 32,08 & 5,92 & 31,90 & 5,61 & $-0,182$ & $-0,52$ & 0,607 \\
\hline E-LS & 20 & $-1,75$ & 1,95 & $-2,57$ & 1,79 & $-0,815$ & $-6,686$ & $0,000002^{*}$ \\
\hline IS.PP & 20 & 68,18 & 7,28 & 66,82 & 7,66 & $-1,36$ & $-0,691$ & 0,497 \\
\hline IS-PP & 20 & 27,66 & 2,66 & 28,17 & 3,03 & 0,51 & 2,223 & $0,038^{*}$ \\
\hline FMA & 23 & 23,93 & 5,67 & 23,41 & 5,48 & $-0,521$ & $-1,873$ & 0,074 \\
\hline SN.Gn & 23 & 68,62 & 3,48 & 68,61 & 3,53 & $-0,0043$ & $-0,014$ & 0,989 \\
\hline AFAI & 23 & 64,23 & 4,81 & 65,12 & 4,69 & 0,887 & 3,066 & $0,0056^{*}$ \\
\hline SND & 23 & 74,08 & 2,72 & 74,42 & 2,78 & 0,339 & 1,05 & 0,304 \\
\hline PTV-CM & 23 & 20,50 & 3,31 & 21,71 & 3,48 & 1,208 & 3,893 & $0,00078^{*}$ \\
\hline PTV-CPm & 20 & 41,91 & 3,82 & 39,05 & 3,82 & $-2,86$ & $-6,503$ & $0,000003^{*}$ \\
\hline PTV-IS & 20 & 57,22 & 4,09 & 58,0 & 4,65 & 0,775 & 1,769 & 0,0929 \\
\hline PP.CM & 23 & 111,23 & 6,12 & 103,60 & 6,17 & $-7,63$ & $-8,983$ & $0,000000^{*}$ \\
\hline PP.CPm & 20 & 87,77 & 5,82 & 98,0 & 5,22 & 10,23 & 5,888 & $0,000011^{*}$ \\
\hline PP-CM & 23 & 17,31 & 2,09 & 18,05 & 2,30 & 0,739 & 3,366 & $0,0027^{*}$ \\
\hline PP-CPm & 20 & 20,83 & 2,57 & 21,14 & 2,62 & 0,31 & 1,498 & 0,1503 \\
$*$ & $*$ & & & & & \\
\hline
\end{tabular}

* significância estatística ao nível de 5\% 
Observa-se que, do total das vinte variáveis, sete delas possuem um número menor de pacientes, em vez do total de 23 pacientes, nestas constam 20 pacientes. Isso ocorreu devido a um atraso na realização da segunda tomada radiográfica em três pacientes que se apresentaram resistentes, talvez devido ao custo financeiro. Desta forma, em ambos os três pacientes, quando da tomada da telerradiografia em norma lateral pósnivelamento, esses já se encontravam na fase de retração dos pré-molares superiores, o que comprometeria os resultados obtidos em relação aos prémolares e incisivos superiores, além de uma possível alteração na posição do lábio superior.

O teste $t$ pareado demonstrou que, das 20 variáveis avaliadas, 9 revelaram alterações estatisticamente significantes ao nível de significância de $5 \%$. Dessas, apenas duas são esqueléticas, o ANB e a AFAI. A alteração no perfil mole foi detectada apenas para a medida E-Ls e as demais 6 alterações consistiram em medidas dentárias, que se seguem: IS-PP, PPCM, PTV-CM, PTV-CPm, PP.CM e PP.CPm.

As alterações esqueléticas foram mínimas. O ângulo SNA sofreu uma discreta diminuição de $0,19^{\circ}$ e o SNB, um pequeno aumento de $0,31^{\circ}$, assim como o SND, que aumentou $0,33^{\circ}$, não significantes estatisticamente. Conclui-se que não foram influenciados pela mecânica empregada. Por outro lado, o ângulo ANB diminuiu significantemente de 4,79em média para $4,26^{\circ}$, significante ao nível de $5 \%$, provavelmente devido ao somatório das alterações no ângulo SNA e SNB.

Já a altura facial ântero-inferior (AFAI) aumentou significantemente ao nível de significância de 1\%, de 64,23mm para 65,12mm. As demais medidas do padrão facial, SN.GoGn, FMA e SN.Gn, não se alteraram significantemente.

As variações tegumentares restringiram-se somente à retrusão significativa do lábio superior em relação à linha $E$, representada pela diminuição da variável E-Ls de $-0,815 \mathrm{~mm}$, ao nível de significância de $1 \%$. 0 
ângulo nasolabial e o lábio inferior não se alteraram significantemente em decorrência da mecânica empregada.

As principais mudanças ocorreram ao nível dentário. Os incisivos superiores extruíram $0,51 \mathrm{~mm}$, significante estatisticamente ao nível de $5 \%$. Contudo, não se observou qualquer outra alteração no que tange ao seu posicionamento ântero-posterior e inclinação vestibulolingual.

Os primeiros pré-molares superiores apresentaram alterações significativas no posicionamento ântero-posterior e inclinação mesiodistal, ao nível de significância de 1\%. Os pré-molares distalizaram significantemente, o que foi demonstrado pela diminuição da medida PTV-CPm em 2,86mm. Isso ocorreu provavelmente devido à ação das fibras transeptais, que promoveram uma retração espontânea desses dentes muito importante para a continuidade do tratamento ortodôntico. Além disso, determinou-se uma verticalização desejável dos primeiros pré-molares, anteriormente inclinados para mesial (pela ação do aparelho Pendulum), observada pelo aumento do ângulo PP.CPm em 10,23․ No sentido vertical, observourse uma pequena extrusão, porém não significativa estatisticamente.

Os primeiros molares superiores alteraram significantemente em todas as medidas analisadas ao nível de significância de 1\%. No posicionamento ântero-posterior, houve uma leve mesialização representada pelo aumento de 1,2mm na variável PTV-CM. Verticalmente, determinourse uma extrusão significativa, com o aumento de $0,73 \mathrm{~mm}$ na medida PP-CM. A variável PP.CM diminuiu significantemente em 7,63ํㅡ, revelando uma verticalização efetiva do molar com o emprego do aparelho ortodôntico fixo e AEB, de uso noturno. 


\section{1 - ANÁLISE DO ERRO METODOLÓGICO:}

Para analisar o erro metodológico, as telerradiografias em norma lateral pós-distalização e pós-nivelamento de 10 pacientes foram retraçadas após o período de duas semanas, totalizando 20 traçados cefalométricos refeitos. Os mesmos critérios pré-estabelecidos foram rigorosamente seguidos. Formaram-se assim dois grupos: um constando dos traçados realizados inicialmente (pós-distalização e pós-nivelamento), comparados com os traçados (pós-distalização e pós-nivelamento) confeccionados transcorridos 15 dias. Assim, compararam-se dois traçados realizados em tempos diferentes da mesma telerradiografia em norma lateral. Os dados foram dispostos em tabelas do programa Excel e encaminhados para a análise estatística para a verificação do erro sistemático e casual intraexaminador.

\section{Erro Casual:}

O erro casual transcreve a demarcação de pontos cefalométricos ou do próprio traçado em locais diferentes entre um traçado e outro. É determinado pelo teste do erro de DAHLBERG, definido pela fórmula:

$$
E^{2}=\frac{d^{2}}{2 n}
$$

Sendo, "d" = diferença entre as mensurações de uma mesma variável.

"n" = número de pares de cefalogramas comparados.

\section{Erro sistemático:}

Pelo erro sistemático, entende-se a demarcação diferente de pontos ou mesmo de todo o traçado sempre para o mesmo local ou direção, 
refletindo uma tendência de erro para mais ou menos do valor inicial. É quantificado pelo teste $t$ de Student para dados pareados empregado nos valores obtidos na primeira medição confrontados com aqueles realizados na segunda medição. Valores de $p$ menores que 0,05 , traduzem diferenças estatisticamente significantes para um nível de significância de 5\%.

\section{Tabela 2 : Resultado do teste $\boldsymbol{t}$ de Student para dados pareadose Dahlberg para análise do erro metodológico}

\begin{tabular}{|c|c|c|c|c|c|c|c|}
\hline & X 1 & DP 1 & X 2 & DP 2 & ERRO & $t$ & p \\
\hline SNA & 81,28 & 2,95 & 81,64 & 3,19 & 0,654 & 1,806 & 0,08 \\
\hline SNB & 76,41 & 3,24 & 76,92 & 3,61 & 0,711 & 2,519 & $0,02^{*}$ \\
\hline ANB & 4,97 & 1,85 & 4,89 & 1,85 & 0,229 & 0,997 & 0,333 \\
\hline E-Linf & 0,06 & 3,52 & $-2,08$ & 3,64 & 0,246 & 0,70 & 0,49 \\
\hline Nasolabial & 104,85 & 10,33 & 104,57 & 9,04 & 2,03 & 0,37 & 0,71 \\
\hline SN.GoGn & 32,94 & 5,24 & 32,59 & 5,20 & 0,582 & 1,81 & 0,08 \\
\hline E-Lsup & $-2,05$ & 1,65 & $-2,17$ & 1,74 & 0,386 & 0,86 & 0,401 \\
\hline IS.PP & 66,81 & 7,21 & 66,8 & 8,01 & 0,903 & 0,018 & 0,985 \\
\hline IS-PP & 28,2 & 1,43 & 28,03 & 1,44 & 0,40 & 1,156 & 0,264 \\
\hline FMA & 24,43 & 4,46 & 24,65 & 4,44 & 0,459 & 1,381 & 0,186 \\
\hline NS.Gn & 69,76 & 3,90 & 69,34 & 4,10 & 0,536 & 2,545 & $0,021^{*}$ \\
\hline AFAI & 66,58 & 3,20 & 66,48 & 3,22 & 0,499 & 0,518 & 0,611 \\
\hline SND & 73,99 & 3,41 & 74,49 & 3,55 & 0,544 & 3,274 & $0,004^{*}$ \\
\hline PTV-CM & 19,50 & 2,973 & 19,57 & 3,45 & 0,646 & 0,291 & 0,774 \\
\hline PTV-CPm & 38,28 & 3,02 & 38,50 & 3,20 & 0,709 & 0,864 & 0,40 \\
\hline PTV-IS & 55,78 & 3,92 & 56,17 & 4,53 & 0,884 & 1,257 & 0,226 \\
\hline PP.CM & 105,25 & 7,18 & 105,39 & 7,04 & 2,169 & 0,173 & 0,864 \\
\hline PP.CPm & 95 & 5,58 & 95,3 & 6,01 & 2,038 & 0,404 & 0,691 \\
\hline PP-CM & 18,43 & 2,10 & 18,42 & 2,04 & 0,438 & 0,078 & 0,938 \\
\hline PP-CPm & 21,71 & 1,278 & 21,94 & 1,58 & 0,508 & 1,311 & 0,208 \\
\hline
\end{tabular}

\footnotetext{
* significante ao nível de significância de 5\%
} 
Após a análise dos resultados anteriores, observa-se que, do total de 20 medidas avaliadas, apenas 3 (SNB, NS.Gn e SND) revelaram uma diferença estatisticamente significante, num nível de significância de $5 \%$. Considerando-se que estas 3 medidas equivalem a $15 \%$ da totalidade das medidas; e principalmente que, a diferença média entre um traçado e outro no erro sistemático dessas medidas compreendeu no máximo $0,5^{\circ}$, conclui-se que essa variação, apesar de estatisticamente significante, não influencia clinicamente nos resultados obtidos. Portanto, o erro metodológico não se apresentou significante. 
DISCUSSÃO 


\section{DISCUSSÃO}

Visando a uma melhor interpretação dos resultados obtidos neste estudo, torna-se de fundamental importância o esclarecimento sobre a metodologia empregada, características da amostra e tratamento ortodôntico realizado. Assim, dividiu-se este capítulo em:

6.1 - Precisão da metodologia;

6.2 - Considerações sobre a amostra;

6.3 - Tratamento ortodôntico;

6.4 - Efeitos esqueléticos pós-distalização com o aparelho Pendulum;

6.5 - Efeitos dentários pós-distalização por meio do aparelho Pendulum;

6.6 - Efeitos pós-distalização no perfil mole;

6.7 - Considerações clínicas.

\section{1 - PRECISÃO DA METODOLOGIA}

Para a obtenção de resultados mais fidedignos, foram utilizados alguns recursos durante a realização deste estudo. Inicialmente, selecionou-se os pacientes seguindo rigorosamente os critérios da seleção previamente descritos. Além disso, cabe salientar que, anteriormente, os pacientes foram submetidos ao tratamento distalizador com 0 aparelho Pendulum realizado por um mesmo operador, incluindo a fase laboratorial. A partir da obtenção da relação molar de Classe I sobrecorrigida, os pacientes passaram a ser tratados por apenas dois profissionais, calibrados para a realização dos procedimentos ortodônticos determinados neste estudo.

Para a padronização da técnica radiográfica, as telerradiografias, em norma lateral, foram obtidas, em sua maioria, em um 
mesmo centro de documentação, conseqüentemente num mesmo aparelho radiográfico, com exceção apenas de uma telerradiografia. Adicionado a isso, os técnicos responsáveis pela realização do procedimento encontravam-se treinados, seguindo um mesmo protocolo ${ }^{60}$.

Nas fases de remoção do aparelho Pendulum e no término do alinhamento e nivelamento do arco dentário superior, requisitaram-se telerradiografias em norma lateral. Devido provavelmente a dificuldades financeiras, três pacientes da amostra realizaram a segunda tomada radiográfica já na fase de retração dos pré-molares superiores. Em decorrência das alterações causadas nos pré-molares e incisivos superiores pela retração mecânica superior em andamento, descartaram-se esses pacientes para as medidas concernentes a esses elementos dentários. Pode-se pensar que os primeiros molares superiores também seriam afetados, face à perda de ancoragem resultante do processo da retração dos pré-molares. Contudo, após a obtenção dos resultados, observourse que as medidas referentes ao primeiro molar superior desses pacientes comportaram-se em total consonância com os demais. Diante disso, com exceção das medidas referentes aos pré-molares e incisivos superiores, todas as outras medições foram realizadas na totalidade da amostra.

A partir da aquisição das telerradiografias em norma lateral, traçaram-se os cefalogramas. Todos os cefalogramas foram realizados por um mesmo profissional, utilizando um só negatoscópio, em sala obscurecida $^{60}$. Os pontos cefalométricos foram demarcados e as medições realizadas pelo programa Dentofacial Planner 7.0. Para comprovar a confiabilidade dos traçados e medições realizadas, decorridos quinze dias, vinte telerradiografias iniciais e finais de dez pacientes (correspondendo a $43 \%$ da amostra) escolhidas aleatoriamente, foram retraçadas para a realização do erro do método. Observa-se pelo erro de Dahlberg que somente em três medidas houve uma variação aleatória maior que 2 . Também, com relação ao erro sistemático e tendencioso quantificado pelo teste $t$ para dados pareados, ocorreu significância estatística para três 
medições, o que corresponde a apenas 15\% da totalidade das medidas realizadas, e em pequena magnitude, de no máximo $0,5^{\circ}$, não significante clinicamente. Portanto, esses dados não comprometem a não-significância geral do erro do método. Desta forma, os dados encontrados neste estudo tornam-se confiáveis e passíveis de reprodutibilidade sem alterações significantes.

As grandezas cefalométricas utilizadas foram determinadas de maneira a minimizar ou mesmo evitar que efeitos simultâneos em outros locais do complexo craniofacial pudessem inviabilizar a veracidade das alterações específicas avaliadas.

As medidas esqueléticas destinavam-se a analisar alterações sagitais na maxila e mandíbula em relação à base do crânio, assim como entre si, por meio dos ângulos SNA, SNB, SND e ANB. Apesar da variação desses ângulos em relação à norma pré-estabelecida decorrente de diferentes angulações da base do crânio, essa não comprometeria significantemente os resultados deste estudo, já que as medições caracterizavam-se por longitudinais, não havendo maior importância na classificação transversal dos pacientes e, sim, nas alterações ocorridas no período observado.

As demais grandezas cefalométricas esqueléticas referiram-se ao padrão facial: SN.GoGn, FMA, NS.Gn e AFAI, amplamente empregadas na literatura. Cabe atentar que a AFAl sofre modificações em decorrência da disposição ântero-posterior da maxila e mandíbula, quando obtida pela distância linear do ponto ENA ao Me. Para minimizar esse efeito, uma das alternativas constitui-se na sobreposição deste pontos à linha $N$ perpendicular ao Plano de Frankfurt. Porém, neste estudo, realizou-se a medição linearmente do ponto ENA ao Me simplesmente, devido ao conhecimento prévio de que não haveria alterações sagitais significativas da maxila e mandíbula ${ }^{99}$, não interferindo significantemente num estudo longitudinal. 
Para a análise do perfil mole, utilizaram-se medidas baseadas na distância perpendicular dos pontos Lábio Superior (Ls) e Lábio Inferior (Li) ao plano referencial da Linha E, proposto por RICKETTS ${ }^{110}$. Preferiu-se essa medida devido à menor subjetividade na demarcação dos pontos, comparada à linha $\mathrm{S}$ para análise do perfil mole e à alta compatibilidade clínica, facilitando a interpretação dos resultados obtidos.

A avaliação dentária deteve-se em alguns pontos cefalométricos empregados para análise dos molares e pré-molares superiores em recentes estudos sobre os aparelhos distalizadores intrabucais. De acordo com GHOSH, NANDA ${ }^{52}$; BYLOFF, DARENDELILER ${ }^{30}$; BYLOFF et al. ${ }^{31}$; NGANTUNG, NANDA, BOWMAN ${ }^{99}$ e CHAQUÉS-ASENSI, KALRA ${ }^{36}$ o ponto do centro da coroa clínica, determinado pelo ponto médio da linha que une a maior convexidade da face mesial e distal, constitui-se no método mais confiável para medir alterações na inclinação dentária dos dentes posteriores. Convencionalmente, se emprega a cúspide mesiovestibular do primeiro molar superior, porém essa movimenta-se demasiadamente quando da inclinação dentária para distal, não refletindo o movimento real do molar superior. Além disso, a cúspide mesiovestibular apresenta maiores dificuldades para visualização, acentuada pela sobreposição de imagens. A fim de padronizar o desenho anatômico dos dentes e, assim, a localização do ponto do centro da coroa clínica, utilizourse o método da sobreposição, minimizando as variações na realização do desenho anatômico dentário, que interfeririam na determinação das alterações ocasionadas nesses elementos dentários.

Realizou-se o método de sobreposição também para a realização do desenho anatômico da fissura pterigomaxilar, quando essa se apresentou em imagem duplicada. Para que não houvesse alterações na localização sagital do desenho anatômico do primeiro para o segundo traçado cefalométrico, sobrepôs-se o desenho realizado na primeira telerradiografia à segunda, na linha $\mathrm{SN}$, no ponto $\mathrm{S}$. Esses cuidados no desenho anatômico da fissura pterigomaxilar deveram-se à importância 
dessa estrutura na determinação de alterações ântero-posteriores no posicionamento dos dentes superiores, verificadas pela distância desses à linha PTV. Como afirmado por ENLOW; KURODA; LEWIS ${ }^{43}$ essa linha representa um referencial bastante confiável, já que não se altera significantemente ântero-posteriormente em decorrência do crescimento craniofacial, sendo por isto amplamente utilizada na literatura como plano de referência sagital ${ }^{30,44,49,52,87,99,115}$.

As alterações dentárias relacionadas à inclinação mesiodistal e ao sentido vertical tiveram como plano de referência o plano palatino, coadunando com vários estudos na literatura ${ }^{23,24,30,31,36,44,52,99}$. Alguns estudos utilizaram-se da linha $\mathrm{SN}^{67,115}$, outros do Plano de Frankfurt ${ }^{49}$. Porém, considerando-se a possibilidade da rotação do plano palatino em decorrência da mecânica empregada, observa-se que a análise dentária, empregando-se referenciais à distância como a linha SN ou o Plano de Frankfurt, não representa somente as alterações ocasionadas nos dentes, mas também está implícita a rotação ocorrida no plano palatino, não traduzindo com fidedignidade as modificações verdadeiramente dentárias. Em decorrência disso, utilizou-se o plano palatino como referencial para as medidas dentárias, por representá-las com maior criteriosidade.

Após o emprego de todos esses cuidados na realização deste estudo, torna-se lícito afirmar que os resultados obtidos traduzem seguramente a veracidade das alterações ocorridas no período avaliado, considerando-se a precisão do instrumento de mensuração utilizado.

\section{2 - CONSIDERAÇÕES SOBRE A AMOSTRA}

A má oclusão de Classe II possui uma alta abrangência dentro da população. Em estudos realizados em crianças americanas brancas, a proporção entre Classe I e Classe II atingia 3:1, respectivamente. ${ }^{93}$ No Brasil, SILVA FILHO; FREITAS; CAVASSAN ${ }^{120}$, em 1989, verificaram a 
prevalência de $42 \%$ da má oclusão de Classe II em crianças naturais da cidade de Bauru-SP, na faixa etária de 7 a 11 anos.

Em decorrência da grande prevalência da má oclusão de Classe II na população e da maior procura por tratamento ortodôntico em detrimento do comprometimento estético bastante significativo, vários autores, no decorrer do tempo, estudaram as características morfológicas da Classe II, como também procuraram estabelecer formas de tratamento mais adequadas.

Com o advento das radiografias cefalométricas, pôde-se comprovar que, além dos comprometimentos dentários, havia também alterações esqueléticas, que poderiam abranger a maxila, a mandíbula ou ambas, em diferentes severidades.

Assim, alguns autores na literatura consideram que existe uma maior prevalência da protrusão maxilar na má oclusão de Classe $\|^{5,114,126}$. Outros, que a maxila se encontra em posição de normalidade ${ }^{95,109,111}$ ou mesmo retruída ${ }^{102}$. No presente estudo, observourse que a maxila encontrava-se em posição de normalidade em relação à base do crânio, representada pelo valor médio do ângulo SNA de 80,99², comparado aos dados da normalidade disponíveis no Atlas de Crescimento Craniofacial ${ }^{91}$ de $81,6^{\circ}$, desvio padrão de $3,2^{\circ}$ para o gênero feminino e $82,3^{\circ}$, desvio padrão de $2,7^{\circ}$ para o masculino, referentes à idade de 15 anos.

Considerando-se os pacientes individualmente, observou-se que em $13 \%$ deles houve suave protrusão maxilar; em outros 13\%, leve retrusão; e, nos demais, 74\%, a maxila encontrou-se bem posicionada em relação à base do crânio.

A grande maioria dos autores considera a retrusão mandibular como fator de maior prevalência na má oclusão de Classe $\|^{69,71,78,95,97,102,}$ 109, 111. Apenas uma minoria afirma que a mandíbula encontra-se normal em relação à base do crânio ${ }^{5,114}$. 
Neste estudo, confirmaram-se os resultados da literatura de que há uma prevalência da retrusão mandibular (em relação à base do crânio) na má oclusão de Classe II, comprovada pela medida angular média do SNB de 76,22을 inferior aos valores da normalidade para a idade de 15 anos de $79,8^{\circ}$, para o gênero feminino e $79,5^{\circ}$, para o masculino, considerando-se inclusive seu desvio padrão ${ }^{91}$. Analisando-se a amostra individualmente, verificou-se que $52,2 \%$ dos pacientes demonstrou retrusão mandibular enquanto $47,8 \%$, um bom posicionamento mandibular em relação à base do crânio, o que foi confirmado pelos dados obtidos utilizando-se a medida angular SND, empregando-se como valor padrão a média proposta por STEINER de 76ㅇ․

A relação maxilomandibular representada pela grandeza angular ANB refletiu uma desarmonia entre as bases ósseas apicais, pois o valor médio do ANB de 4,79 apresentou-se superior aos dados da normalidade de $1,7^{\circ}$ para o gênero feminino e 2,8으. para o masculino, na idade de 15 anos $^{91}$. Individualmente, o ANB demonstrourse dentro dos valores da normalidade em $47,8 \%$ dos pacientes e aumentado, em $52,2 \%$. Este dado revela que além do comprometimento dentário, havia um suave comprometimento esquelético na má oclusão de Classe II apresentada pelos pacientes da amostra avaliada neste estudo, causada por uma leve retrusão mandibular.

Analisou-se o relacionamento vertical pelas medidas SN.GoGn, FMA, NS.Gn e AFAl. Notou-se que os pacientes apresentavam-se com padrão de crescimento com tendências horizontais, determinado pelos

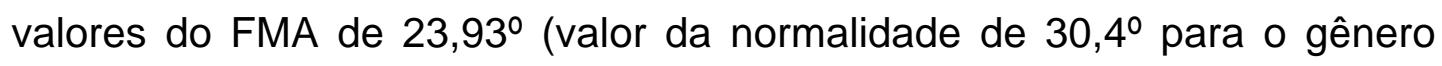
feminino e $28,8^{\circ}$, para o masculino ${ }^{91}$ ) e do SN.GoGn de $32,08^{\circ}$ (dados normais de $31^{\circ}$ para o gênero feminino e $32,9^{\circ}$, para o masculino ${ }^{91}$ ), respectivamente à idade média de 15 anos. Somente $30,4 \%$ da amostra apresentava-se com tendência suave de crescimento vertical. Com isso, comprova-se que esses pacientes apresentavam um padrão de crescimento favorável a um tratamento distalizador sem extrações dentárias ${ }^{70,87,113}$. 
Quanto ao comportamento dos dentes com o osso basal, cabe ressaltar o posicionamento ântero-posterior do primeiro molar superior em relação à linha PTV, determinado por RICKETTS ${ }^{110}$. Segundo esse autor, o primeiro molar superior deve se posicionar na idade de 15 anos a uma distância média de 12 a 18mm da linha PTV, sendo que, nos pacientes em questão, o primeiro molar superior localizava-se previamente ao tratamento distalizador, a 25,33mm da linha PTV, em média, dado obtido em estudo anterior, utilizando a mesma amostra deste trabalho ${ }^{49}$. No presente estudo, em que os primeiros molares superiores já se encontravam distalizados, essa medida diminuiu para $20,5 \mathrm{~mm}$, o que refletiu a melhora proporcionada pelo tratamento distalizador à relação sagital do primeiro molar superior no complexo dentofacial.

Devido aos diferentes comprometimentos esqueléticos existentes na má oclusão de Classe II, diversos tipos de tratamentos são propostos na literatura, na dependência do principal fator acometido. Devese realizar uma avaliação criteriosa dos pacientes, a fim de se determinar o tratamento ortodôntico mais adequado ${ }^{95,96}$.

$\mathrm{Na}$ análise dos pacientes pertencentes à amostra, notourse que houve uma prevalência do posicionamento normal da maxila e uma leve retrusão mandibular em relação à base do crânio, demonstrando suave comprometimento esquelético. Adicionado ao padrão de crescimento horizontal e ao posicionamento inicial dos primeiros molares superiores demasiadamente por mesial, conclui-se que o tratamento distalizador empregado nesses pacientes apresentoutse como uma opção favorável da terapêutica ortodôntica disponível para a correção da má oclusão de Classe II.

\section{3 - TRATAMENTO ORTODÔNTICO}

A tendência atual da Ortodontia consiste no tratamento das más oclusões baseado nas filosofias não extracionistas, evidenciada pela 
proliferação dos expansores maxilares, dos diferentes tipos de aparelhos extrabucais e aparelhos ortopédicos funcionais fixos e removíveis. Estas terapêuticas eliminam alguns dos problemas relacionados às extrações: reabertura dos espaços, perfil facial acentuadamente abandejado, alterações periodontais e tendência ao aprofundamento da sobremordida. ${ }^{32}$

Inicialmente, para o tratamento conservador da Classe II propôs-se o uso dos aparelhos ortopédicos funcionais ${ }^{63}$, seguidos do aparelho extrabucal ${ }^{81,82}$, com a finalidade da distalização dos molares superiores e restrição do crescimento maxilar para anterior.

BISHARA et al. ${ }^{17}$, em 1997, afirmou que a má oclusão de Classe II apresenta-se de diversas formas na população, em consonância às diferentes interações dos tecidos ósseos, dentários e moles. Dessa forma, a Classe II pode caracterizar-se por uma protrusão maxilar e/ou retrusão mandibular, ou mesmo ausência de comprometimentos esqueléticos. A partir do correto diagnóstico, deve-se indicar o tratamento mais adequado. Assim, para a Classe II com suave acometimento esquelético combinada a um padrão facial com predomínio do crescimento horizontal, o tratamento mais indicado consiste na distalização dos molares superiores ${ }^{35,56,96 .}$

As primeiras terapêuticas utilizadas para a distalização dos molares superiores dependiam excessivamente da colaboração do paciente: O aparelho extrabuca ${ }^{32,40,41,42,81,8598}$, O aparelho removível ACCO combinado ao aparelho extrabucal ${ }^{9,35,45,53,75}$, arco de Wilson ${ }^{66,97, ~ 127, ~ 128, ~} 129$, e outros $^{51,112,119}$. Apesar dessas mecânicas proporcionarem a correção da Classe II, o índice de insucesso apresenta-se bastante significativo, principalmente em detrimento da falta de colaboração dos pacientes ${ }^{1,38,45}$. Como JARABAK ${ }^{73}$ afirmou em 1965, a falta de cooperação dos pacientes pode destruir o melhor plano de tratamento e mecânica ortodôntica. Com isso, no decorrer do tempo, vários autores desenvolveram novas técnicas e aparelhos ortodônticos que não dependessem totalmente da cooperação dos pacientes para atingirem sucesso. 
Dessa forma, para a distalização dos molares superiores, independente da colaboração excessiva dos pacientes, surgiram os magnetos repelentes ${ }^{58,59,72}$, as molas abertas de níqueltitânio ${ }^{50,57,104}$, os fios de níquel-titânio superelásticos ${ }^{54,77,86,90,0}$ aparelho de Nance modificado ${ }^{106,} 108$ o Jones Jig 67, 76, 115, 121, 123, o Distal Jet 25, 26, 34, 99, 107, o Pendulum 29, 30, 31, 36, 49, 52, 70, 87 , dentre outros ${ }^{48,64,79}$. Todos esses aparelhos demonstraram bons resultados na correção da relação molar de Classe II. Contudo, os estudos comparativos entre eles são raros, exceto entre as molas níquel-titânio e os magnetos repelentes, o que explicitou a superioridade das molas níqueltitânio ${ }^{24,44}$. Dessa forma, não há atualmente subsídios científicos para a escolha de um distalizador intrabucal em detrimento do outro, a não ser por opção pessoal ou facilidade de manuseio.

Para a realização deste estudo, optourse pelo aparelho Pendulum, proposto por HILGERS ${ }^{70}$, em 1992, que demonstrou resultados bastante promissores na literatura, além de se caracterizar pela facilidade de confecção e manuseio $29,30,31,36,49,52,70,87$. A distalização dos molares superiores dos pacientes deste estudo foi obtida num período médio de 5,85 meses, compreendendo em média $4,83 \mathrm{~mm}^{49}$. Contudo, observaram-se vários efeitos adversos oriundos da distalização por meio do aparelho Pendulum e comuns aos demais distalizadores intrabucais: mesialização e inclinação mesial dos pré-molares superiores, protrusão e vestibularização dos incisivos superiores; inclinação distal dos primeiros molares superiores; extrusão dos pré-molares, protrusão do lábio superior e inferior, aumento da AFAl e da distância intermolares; diminuição do trespasse vertical e aumento do horizontal, rotação horária da mandíbula $29,30,36,49,52, ;$ dentre alguns relatos contraditórios como a intrusão ${ }^{30,36} /$ extrusão $^{49}$ dos primeiros molares superiores e o aumento ${ }^{49} /$ diminuição ${ }^{29}$ do ângulo nasolabial.

O que podemos depreender da literatura é que a maior parte desses efeitos adversos, principalmente no que se refere às alterações dentárias, seriam revertidos na fase posterior do tratamento, no aparelho ortodôntico fixo $70,87,99,106,121,123,130$. Este é um dos objetivos do presente 
estudo e, para tanto, realizou-se o tratamento ortodôntico posterior à distalização dos molares superiores seguindo os critérios propostos por vários autores ${ }^{87,99,106,121,123,130 .}$

Previamente ao início da terapia ortodôntica fixa, cabe ressaltar a importância da obtenção da sobrecorreção da relação molar de Classe I, em aproximadamente $2 \mathrm{~mm}$. De acordo cm GIANELLY ${ }^{56}$, em 1998, a sobrecorreção torna-se imprescindível devido à mesialização dos molares, que ocorrerá às expensas da perda de ancoragem resultante da retração ântero-superior e durante a verticalização das raízes dos molares distalizados, que promove um movimento mesial das suas coroas. Em decorrência disso, todos os pacientes apresentavam inicialmente uma sobrecorreção da relação molar de aproximadamente $2 \mathrm{~mm}$.

Segundo o próprio HILGERS ${ }^{70}$, em 1992, constatada a sobrecorreção, deve-se estabilizar os molares distalizados imediatamente à remoção do aparelho Pendulum, com uma das formas de contenção: aparelho ortodôntico fixo associado a um arco utilidade superior, aparelho ortodôntico fixo combinado a um ômega por mesial do tubo molar e, preferencialmente, o Botão de Nance combinado ou não ao aparelho extrabucal, de uso noturno. Já RONDEAU ${ }^{113}$ propõs a conversão do aparelho Pendulum em Botão de Nance, pela remoção do braço de extensão aos pré-molares superiores e desativação das molas TMA, ou mesmo pela combinação da barra transpalatina ao Botão de Nance.

No presente estudo, a contenção empregada consistiu no Botão de Nance instalado imediatamente à remoção do aparelho Pendulum, por se tratar de uma forma estável e confiável de contenção, como afirmado por HILGERS ${ }^{70}$, além de caracterizar-se pela facilidade de confecção e

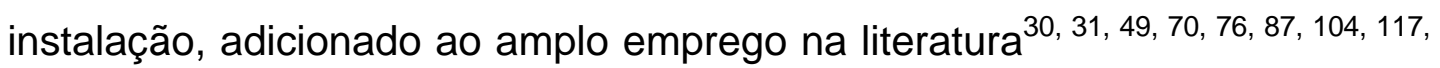
118, 119, 122. 
A seguir, instalou-se um aparelho extrabucal de tração cervical, de uso noturno, com a finalidade de contribuir na contenção e proporcionar a verticalização das raízes dos molares distalizados ${ }^{33,34,36,47,57,67,90,104,115,123 .}$

Devido à necessidade do alinhamento e nivelamento dos arcos dentários e do fechamento do espaço resultante da distalização dos molares, houve a necessidade da instalação do aparelho ortodôntico fixo, que ocorreu transcorridos trinta dias da instalação do aparelho extrabucal, obedecendo o intervalo usual entre as consultas em um consultório particular. $O$ aparelho ortodôntico fixo utilizado constituía-se em préajustado, prescrição ROTH, canaleta 0.022 " x 0.028", escolhido por representar a maior parte dos bráquetes utilizados pelos profissionais de Ortodontia nos consultórios particulares.

O alinhamento e nivelamento do arco dentário superior transcorreu de forma convencional, seguindo-se a seqüência de fios: 0.016 " níquel-titânio, 0.018" e 0.020" aço inoxidável e, finalmente, 0.019" x 0.025" aço inoxidável. Porém, observa-se que o período médio entre uma telerradiografia e outra (pós-remoção do aparelho Pendulum e pósnivelamento e alinhamento) compreendeu 1 ano. Isso se deveu à grande variação do apinhamento ântero-superior inicial, acentuado ainda pela perda

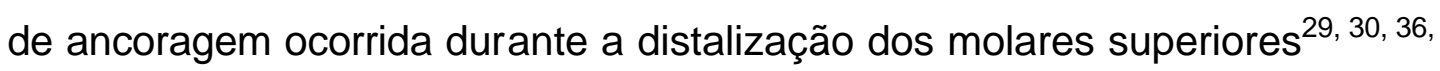
49, 52 Devido a isso, em muitos pacientes, houve a necessidade da instalação inicial do fio 0.014" níquel-titânio e de intervalos maiores que trinta dias para as trocas dos fios, principalmente nos pacientes em que o canino superior encontrava-se em infravestibuloversão. Em decorrência disso, o período entre as duas tomadas radiográficas avaliadas prolongou-se além do esperado, contudo sem afetar contrariamente os resultados, apenas contribuindo na obtenção de dados mais compatíveis com a realidade.

Verificou-se, na literatura, muitos trabalhos sobre os distalizadores intrabucais, porém poucos estudos relatam as alterações ocorridas durante 0 tratamento ortodôntico fixo. ${ }^{99}$ Esses resultados apresentam-se de suma importância para viabilizar o sucesso da terapia 
distalizadora de molares superiores. Com este intuito, propusemo-nos a realizar este estudo e analisar os resultados obtidos.

\section{4 - EFEITOS ESQUELÉtICOS PÓS-DISTALIZAÇÃO COM O APARELHO PENDULUM}

Os efeitos esqueléticos promovidos no período pós-distalização dos molares superiores com o aparelho Pendulum foram divididos em:

6.4.1 - Alterações sagitais na maxila;

6.4.2 - Alterações sagitais na mandíbula;

6.4.3 - Alterações na relação maxilomandibular

6.4.4 - Alterações esqueléticas verticais.

\subsection{1 - Alterações sagitais na maxila}

Durante o período de distalização dos molares superiores por meio do aparelho Pendulum, a maioria dos estudos não encontrou diferença estatística na posição sagital da maxila, quantificada pela grandeza angular SNA $^{30,49,52}$, exceto BUSSICK; Mc NAMARA ${ }^{29}$ que observaram um aumento desse ângulo. Isso reflete que, em geral, a mecanoterapia distalizadora não influencia significantemente o comportamento ântero-posterior da maxila.

O comportamento da maxila permanece semelhante no término do alinhamento e nivelamento do arco dentário superior, em que se verifica que não houve uma diferença estatisticamente significante entre esta fase comparada à remoção do aparelho Pendulum, como demonstrado na figura 18. Este dado coaduna àqueles obtidos por WONG; RABIE; $H_{A} G^{130}$ e MACEDO; AIDAR $^{87}$ que apresentaram casos clínicos finalizados utilizando esta mecânica ortodôntica. 


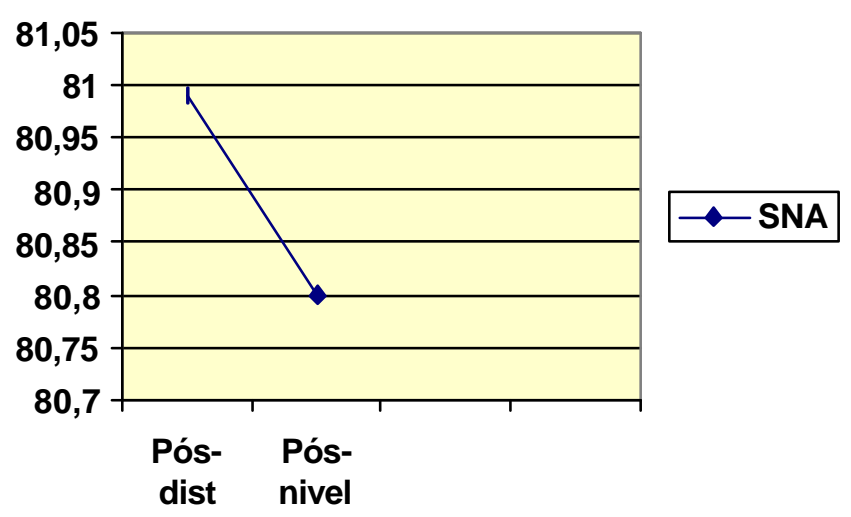

Figura 18 - Alterações sagitais na maxila

Contudo, embora não significante estatisticamente, houve uma diminuição suave do ângulo SNA em $0,191^{\circ}$, o que demonstra uma discreta restrição do crescimento maxilar, que provavelmente ocorreu devido ao uso noturno do aparelho extrabucal, promovendo um discreto efeito ortopédico.

Todavia, em estudo recente, NGANTUNG; NANDA; BOWMAN $^{99}$ ao avaliar pacientes que utilizaram o Distal Jet, afirmaram que a maxila demonstrou um crescimento para anterior de $1 \mathrm{~mm}$, estatisticamente significante, da fase pós-distalização ao final do tratamento ortodôntico com aparelho fixo. A diferença entre os resultados do presente estudo a esse devem-se talvez à idade média mais precoce dos pacientes de 12,8 anos, comparada aos 15 anos e 1 mês deste, o que possibilitou um crescimento maxilar maior nos pacientes mais jovens; aos diferentes tipos de contenção empregados, no presente estudo, o Botão de Nance associado ao aparelho extrabucal e naquele, o Jasper Jumper; ao período de avaliação maior, naquele estudo de 19 meses comparado aos 12 meses deste; e finalmente às diferentes unidades de medida, neste estudo utilizou-se o ângulo SNA e naquele, a distância linear PTV-A, mais expressiva às pequenas alterações e livre das mudanças ocasionadas na base do crânio, principalmente pelo 
ponto $\mathrm{N}$, que também se movimenta para anterior durante o crescimento, mascarando, em alguns casos, o crescimento sagital da maxila ${ }^{32}$.

\subsection{2 - Alterações sagitais na mandíbula}

De forma semelhante, a mandíbula não demonstrou alterações significantes durante a mecânica de distalização dos molares superiores com o aparelho Pendulum, quando avaliada pelos ângulos SNB e $\mathrm{SND}^{30,36,49,52 .}$

No período pós-distalização, já no aparelho ortodôntico fixo, a mandíbula manteve este mesmo comportamento, demonstrando suave aumento dos ângulos SNB e SND, de $0,317^{\circ}$ e 0,339ํㅜㄴ, respectivamente, porém não estatisticamente significantes. (Figura 19) Esse aumento dessas medidas deveu-se estritamente ao crescimento mandibular, que, em decorrência ao curto espaço de tempo analisado e da idade mais avançada dos pacientes, não atingiu significância estatística.

Já NGANTUNG; NANDA BOWMAN ${ }^{99}$, em 2001, obtiveram um aumento ântero-posterior estatisticamente significante da mandíbula, de 2,16mm em média, provavelmente devido ao período de análise maior de 19 meses, comparado aos 12 meses do presente estudo, que proporcionou maior tempo para que o crescimento se expressasse. Além disso, os pacientes se encontravam em uma fase mais precoce, com 12,8 anos, dentro da fase de pico de crescimento puberal, onde há um maior crescimento mandibular; adicionado ainda à unidade de mensuração diferente, a distância PTV-B, que não se altera diante de possíveis variações na base do crânio. 


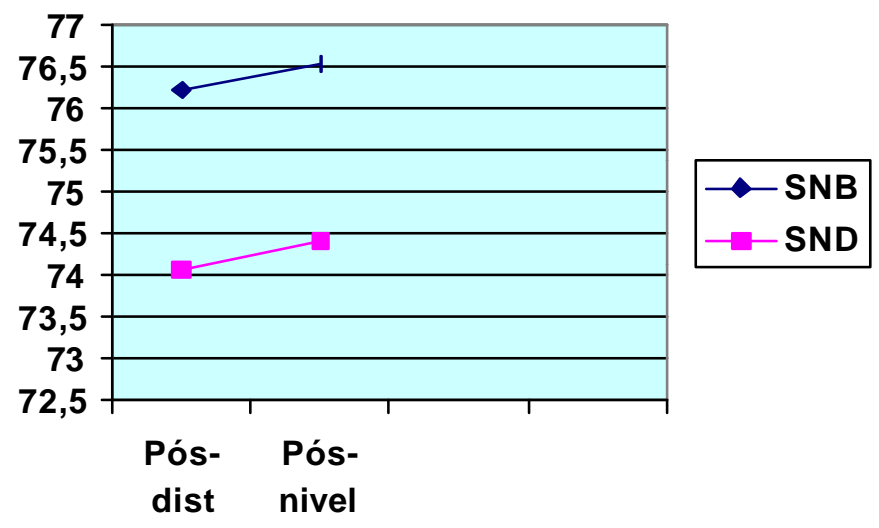

Figura 19 - Alterações sagitais na mandíbula

\subsection{3 - Alterações na relação maxilomandibular}

Em conseqüência do aumento dos ângulos SNB e SND, promovido pelo crescimento mandibular para anterior e da diminuição do SNA, pela restrição do crescimento maxilar, embora individualmente não significantes estatisticamente, quando considerados conjuntamente, determinaram uma melhora estatisticamente significante do ângulo ANB, com uma redução de 0,521ำ, como visto na figura 20 . 


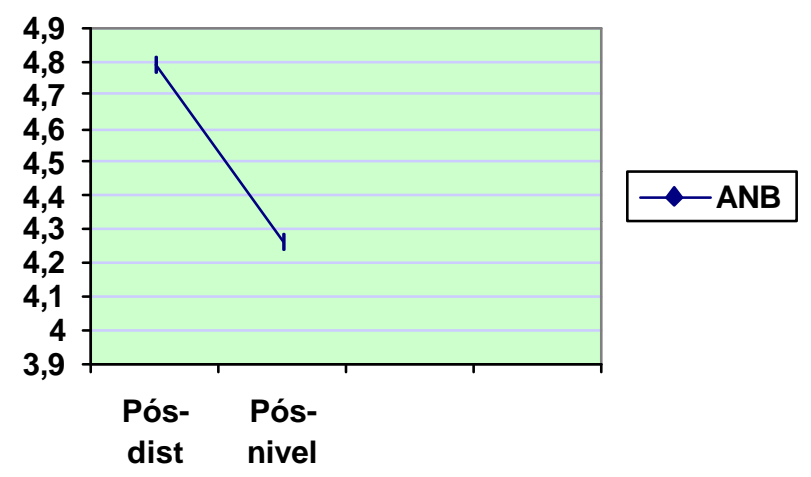

Figura 20 - Alterações na relação maxilomandibular

Isso denota uma melhor relação maxilomandibular resultante do tratamento empregado, proporcionado pelo uso noturno do aparelho extrabucal e pelo crescimento mandibular dos pacientes. Este resultado coaduna com os dados de MACEDO; AIDAR $^{87}$, em 2001, em que o paciente tratado apresentou uma diminuição significativa do ANB ao término do tratamento ortodôntico fixo.

Provavelmente, ao final do tratamento ortodôntico fixo haverá uma melhora do ANB mais expressiva, pois com a realização da retração ântero-superior, ocorrerá uma movimentação posterior do ponto $A, e$, possivelmente, do ponto B para anterior, devido a um crescimento mandibular, promovendo uma redução maior da discrepância existente entre os maxilares.

\subsection{4 - Alterações esqueléticas verticais}

O aparelho Pendulum provoca, no período de distalização dos molares superiores, uma rotação horária da mandíbula, confirmada pelo aumento das medidas SN.GoGn, FMA, NS.Gn e AFAl ${ }^{29,49}$.

No período pós-distalização no aparelho ortodôntico fixo, verificoutse no presente estudo que a mandíbula permanece estável, sem 
qualquer efeito rotacional, representada pelas alterações não significantes estatisticamente das grandezas angulares SN.GoGn, FMA e NS.Gn (figura 21). Assim, observourse que a rotação mandibular no sentido horário ocasionada na fase distalizadora, não se corrigiu com a instalação do aparelho ortodôntico fixo até a fase final de alinhamento e nivelamento do arco dentário superior, permanecendo estável.

Resultado controverso foi encontrado por NGANTUNG; NANDA; BOWMAN ${ }^{99}$, em 2001, em que houve uma redução do FMA estatisticamente significante, devido a uma rotação mandibular no sentido anti-horário, revertendo o efeito ocasionado durante a distalização molar. Provavelmente, isso se deveu ao fato de que a análise desse estudo compreendeu a fase de finalização do tratamento ortodôntico fixo diferente do presente, em que a avaliação aconteceu somente no final do alinhamento e nivelamento do arco dentário superior.

Além disso, verificou-se no presente estudo um aumento significante estatisticamente da altura facial ântero-inferior (AFAl) de $0,887 \mathrm{~mm}$. As causas para esse aumento não podem ser referidas a uma rotação mandibular no sentido horário, pois como visto acima, esta não foi confirmada pelas medidas SN.GoGn, NS.Gn e FMA. Uma possível rotação no sentido anti-horário do plano palatino pode estar associada a esse aumento da AFAl; contudo, o efeito rotacional do plano palatino não foi mensurado neste estudo. Na verdade, o fator principal para explicar esse aumento da AFAl consiste no crescimento vertical normal dos pacientes, como verificado no Atlas de Crescimento Craniofacia ${ }^{91}$, em que entre as idades de 15 e 16 anos observoutse uma variação de 66,7 para 68,3mm, referente ao gênero feminino e de 71,3 para $74,5 \mathrm{~mm}$, para o masculino. Comparando-se o acréscimo ocorrido, para o gênero feminino de $1,6 \mathrm{~mm}$ e para o masculino de $3,2 \mathrm{~mm}^{91}$, observa-se que esses se apresentam bem superiores ao aumento observado no presente estudo de $0,887 \mathrm{~mm}$, o que viabiliza a afirmação de que houve um crescimento vertical significativo no período analisado. 


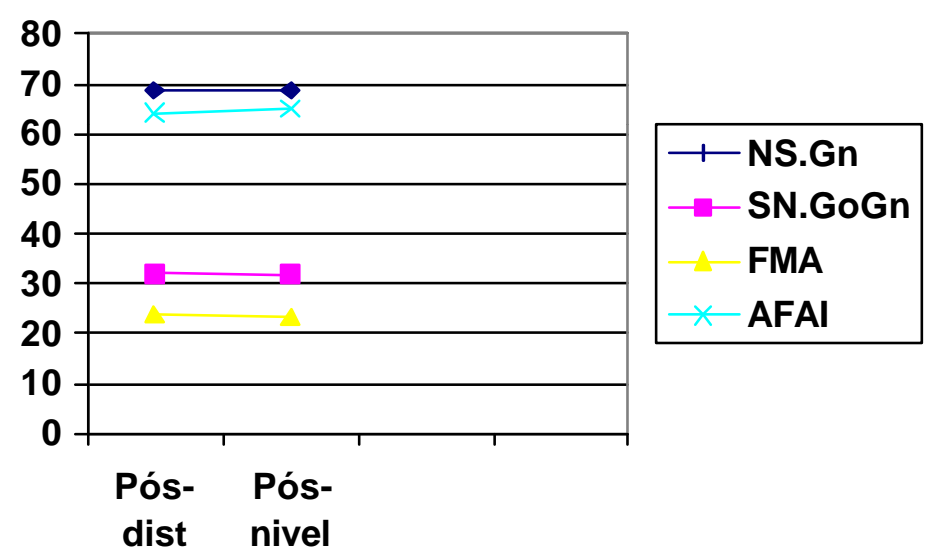

Figura 21 - Alterações esqueléticas verticais

Corroboram deste fato, NGANTUNG; NANDA; BOWMAN $^{99}$ que constataram um aumento da AFAl entre a fases pós-distalização por meio do Distal Jet e na finalização do tratamento ortodôntico com aparelho fixo, determinado pelo crescimento vertical craniofacial normal, comprovado pela diminuição da proporção entre a altura facial ântero-inferior e a altura facial total (AFAI/AFAT) no período avaliado.

\section{5 - EFEITOS DENTÁRIOS PÓS-DISTALIZAÇÃo POR MEIO DO APARELHO PENDULUM}

Para melhor esclarecimento dos efeitos dentários pósdistalização dos molares superiores, durante o tratamento ortodôntico com aparelho fixo, estes serão divididos em:

6.5.1 - Alterações dentárias verticais;

6.5.2 - Alterações nas inclinações dentárias;

6.5.3 - Alterações dentárias sagitais. 


\subsection{1 - Alterações dentárias verticais}

As alterações dentárias verticais foram verificadas, utilizando o plano palatino como linha de referência, medindo-se perpendicularmente ao mesmo. Assim, ainda que houvesse qualquer alteração rotacional do plano palatino durante a mecanoterapia empregada, esta não interferiria nas medições dentárias.

No presente estudo, constatourse uma extrusão estatisticamente significante dos primeiros molares e dos incisivos superiores, respectivamente de 0,739mm e 0,51mm, em média. Já os primeiros pré-molares superiores mantiveram-se estáveis verticalmente no período avaliado (figura 22).

Provavelmente, estes dados correspondem aos resultados a serem obtidos na finalização do tratamento ortodôntico total, visto que coadunam com os achados de NGANTUNG; NANDA; BOWMAN ${ }^{99}$, que analisaram pacientes após a distalização dos molares superiores com 0 Distal Jet, no término do tratamento ortodôntico com aparelho fixo.

A extrusão verificada nos primeiros molares superiores possivelmente foi provocada pelo uso noturno do aparelho extrabucal, tração cervical. Esse efeito extrusivo nos molares superiores devido ao uso do aparelho extrabucal de tração cervical é citado por muitos autores na literatura ${ }^{32,82,14,100}$. Considerando-se que a maior parte dos estudos sobre os efeitos distalizadores do aparelho Pendulum afirma que há uma intrusão dos primeiros molares superiores ${ }^{36,30}$, esta posterior extrusão representa, pelo menos parcialmente, a correção da intrusão anteriormente reportada. 


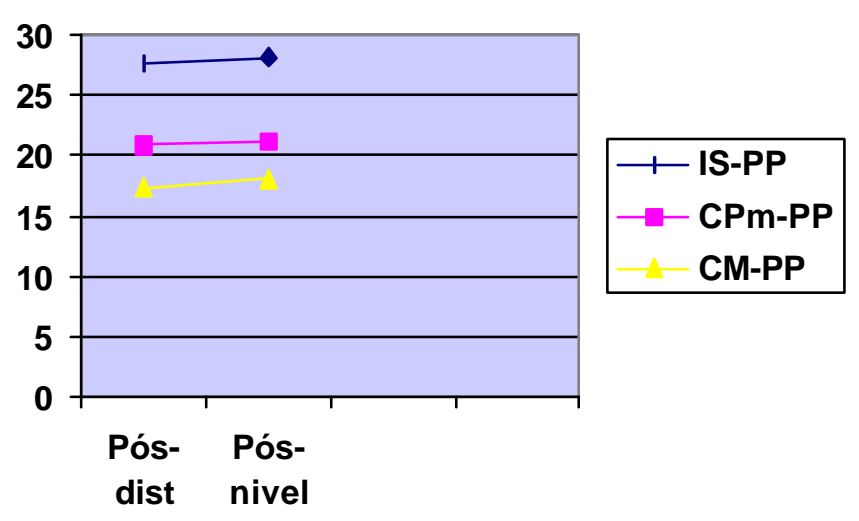

Figura 22 - Alterações dentárias verticais

Verificou-se também que a extrusão dos pré-molares superiores ocorrida durante a distalização dos molares superiores permaneceu estável na fase de tratamento ortodôntico fixo, visto que não houve qualquer alteração vertical entre as fases pós-distalização e pósnivelamento (figura 22).

Apesar da acentuação da Curva de Spee nos arcos superiores instalados na maioria dos pacientes tratados, os incisivos superiores demonstraram uma extrusão estatisticamente significante, contrária ao esperado, talvez em decorrência da própria instalação do aparelho ortodôntico fixo.

\subsection{2 - Alterações nas inclinações dentárias:}

Uma das maiores preocupações relacionadas ao tratamento distalizador de molares superiores diz respeito à significativa inclinação distal verificada nos molares movimentados. Esse movimento para distal promovido principalmente pela inclinação das coroas preocupa diversos autores ${ }^{31,52,56,70}$ que afirmam a característica instável da movimentação, colocando em dúvida a qualidade da finalização do tratamento. 
Vários autores relatam a vantagem da utilização do aparelho extrabucal, de uso noturno, de maneira a contribuir na contenção e

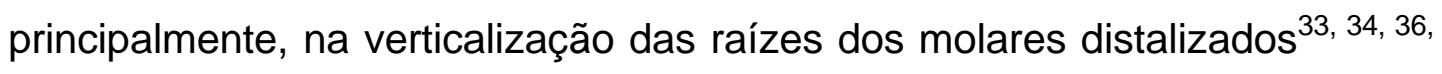
$47,57,67,90,104,115,123$. Baseado nessa premissa, empregoutse esse aparelho no tratamento dos pacientes do presente estudo; contudo, alguns autores não mencionam a necessidade da sua utilização ${ }^{48,76,79,87,99,108 .}$

Tendo-se como referência o plano palatino, observou-se uma inclinação para mesial estatisticamente significante dos primeiros molares superiores de 7,63ํำ entre a fase pós-distalização e pós-nivelamento do arco dentário superior, que se comparada aos resultados provocados pela distalização molar (inclinação distal de $8,36^{051}$ a $14,5^{\circ 30}$ ), traduz-se numa verticalização bastante favorável ao tratamento ortodôntico (figura 23). NGANTUNG; NANDA; BOWMAN ${ }^{99}$, em 2001, também encontraram dado semelhante, com uma verticalização do primeiro molar superior de $6,08^{\circ}$, ao final do tratamento ortodôntico, utilizando como distalizador o Distal Jet. Esse resultado torna a distalização de molares superiores por meio dos aparelhos intrabucais mais confiável, na medida em que, já na finalização do alinhamento e nivelamento do arco dentário superior, o primeiro molar superior assume uma posição mais estável ortodonticamente.

Esse fato confirma a afirmação de GIANELLY ${ }^{56}$, em 1998, em que 0 autor recomenda o início da mecânica de retração somente 4 a 5 meses pós-distalização, visto a natureza instável dos molares imediatamente após a sua distalização. No presente estudo, comprovou-se que, passados 12 meses da finalização da distalização molar, os molares realmente adotaram uma estabilidade maior, representada pela verticalização expressiva de suas raízes.

Porém, como uma conseqüência natural desse movimento de verticalização, tem-se uma maior movimentação para mesial das coroas que das raízes dos molares distalizados ${ }^{56}$, promovendo uma leve perda de ancoragem no sentido ântero-posterior, que será abordada posteriormente. 
A inclinação mesial dos primeiros pré-molares superiores promovida no período distalizador $29,30,36,49,52$ apresentourse completamente corrigida durante o tratamento com aparelho ortodôntico fixo, com a verticalização estatisticamente significante de suas raízes em 10,23을 representada pelo aumento do ângulo CPm.PP de $87,77^{\circ}$ para $98^{\circ}$ (figura 23). Também NGANTUNG; NANDA; BOWMAN ${ }^{99}$, em 2001, observaram essa verticalização dos pré-molares superiores, todavia em menor magnitude de 2,09․ Os pré-molares verticalizaram menos nesse estudo comparado ao presente, devido à natureza diferente da inclinação promovida pelo Distal Jet, em que os pré-molares superiores inclinam-se para distal em decorrência da estrutura do aparelho Distal Jet. Além disso, o alinhamento e nivelamento dentários ocorreram simultaneamente à distalização molar, o que provavelmente reduziu a inclinação inicial para distal dos pré-molares, minimizando conseqüentemente a verticalização posterior.

Este dado contribui bastante para a finalização adequada do tratamento ortodôntico, na medida em que os pré-molares superiores adotam uma posição mais estável clinicamente. Adicionado a isto, esta verticalização das raízes dos pré-molares leva a uma maior movimentação da coroa para distal, contribuindo para a distalização "espontânea' desses dentes em direção ao espaço obtido pela distalização molar, que será reportada posteriormente.

Os incisivos superiores inclinaram para lingual 1,36을 porém não estatisticamente significante (figura 23). A razão para esse fato, consiste na fase do tratamento ortodôntico fixo em que se realizou a segunda tomada radiográfica, em que não havia sido realizada a retração ântero-superior, não modificando por isso a posição e a inclinação dos incisivos superiores significantemente. No estudo de NGANTUNG; NANDA; BOWMAN ${ }^{99}$ em que o tratamento ortodôntico havia finalizado, houve significância estatística na inclinação dos incisivos superiores para lingual de 6,83‥ 


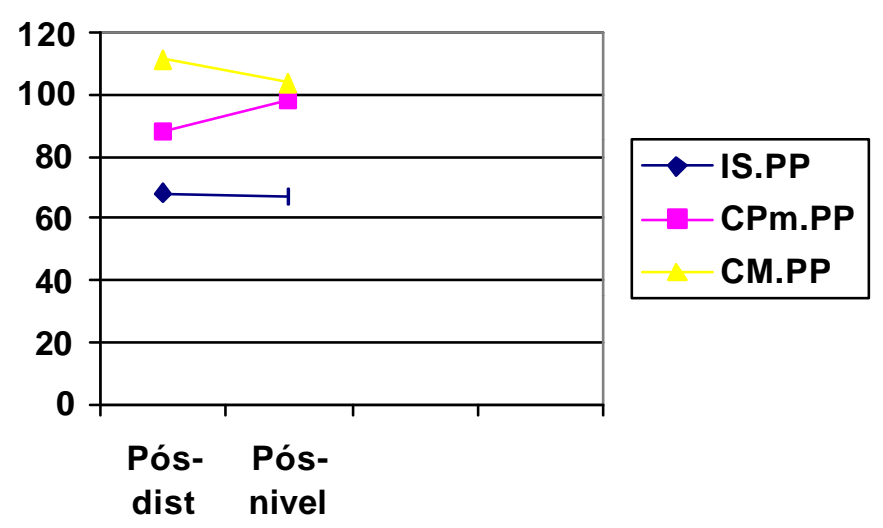

Figura 23 - Alterações nas inclinações dentárias

\subsection{3 - Alterações dentárias sagitais}

O comportamento sagital dos componentes dentários pósdistalização dos molares superiores, durante o tratamento ortodôntico com aparelho fixo, apresenta-se como o principal dentre os demais, já que as alterações almejadas com o emprego do aparelho Pendulum consistem na correção ântero-posterior dos arcos dentários entre si e a permanência desses efeitos é de suma importância.

Dentre os efeitos sagitais provocados pelo aparelho Pendulum durante a distalização dos molares superiores destacam-se: a distalização dos primeiros molares superiores de $3,37^{52}$ a $5,7 \mathrm{~mm}^{29}$, corrigindo a relação molar de Classe II para Classe P9, 30, 49, 70; mesialização dos pré-molares de $1,8{ }^{29}$ a 2,55mm ${ }^{52}$ e protrusão dos incisivos superiores de $0,8^{29}$ a $1,56 \mathrm{~mm}^{49}$.

A situação almejada para a continuidade do tratamento ortodôntico com sucesso corresponde à estabilidade do posicionamento por 
distal dos molares superiores e a distalização/retração dos pré-molares e incisivos superiores em direção ao espaço obtido pela distalização molar.

\section{Incisivos superiores}

Apesar dos incisivos superiores protruírem significantemente em $0,8{ }^{29}$ a $1,08 \mathrm{~mm}^{49}$ no período de distalização dos molares superiores por meio do aparelho Pendulum, esses não apresentaram alterações sagitais estatisticamente significantes na fase do tratamento ortodôntico fixo avaliada neste estudo (no término do alinhamento e nivelamento superiores) (figura $24-p g$ 142).

Espera-se que os incisivos superiores ao final do tratamento apresentem uma retrusão significante estatisticamente ${ }^{99}$, não observada no presente estudo, visto que a retração ântero-superior não foi realizada no momento da segunda tomada radiográfica avaliada.

\section{Primeiro pré-molar superior}

No período compreendido entre a remoção do aparelho distalizador e o término do alinhamento e nivelamento do arco dentário superior, os primeiros pré-molares superiores distalizaram espontaneamente, em média, 2,86mm, dado determinado pela diminuição da medida CPm-PTV, estatisticamente significante ao nível de 1\% (figura 24 - pg 142), fato corroborado por outros autores 10, 26, 30, 54, 90, 117, 130 . Segundo SCUZZO; PISANI; TAKEMOTO ${ }^{117}$, em 1999, o segundo pré-molar superior leva em média de 2 a 3 meses para distalizar completamente. Vale ressaltar que até o momento da segunda tomada radiográfica analisada, não se realizou qualquer tipo de mecânica de retração dos pré-molares ou incisivos, o que possibilita a terminologia de "distalização espontânea" dos prémolares superiores. 
Essa distalização espontânea de ambos os pré-molares superiores representa a reversão total da mesialização ocorrida durante a distalização dos molares superiores com o aparelho Pendulum, que variou de $1,8^{29}$ a $2,55 \mathrm{~mm}^{52}$.

Esta distalização espontânea correlaciona-se à significativa verticalização dos pré-molares superiores de $10,23^{\circ}$, o que promoveu a maior movimentação para distal da coroa comparada à raiz, levando à distalização dos pré-molares observada radiográfica e clinicamente.

Contudo, tratando-se de uma movimentação para distal, em média de 2,86mm, fica claro que essa não se deve somente a uma desinclinação dentária. Houve também uma movimentação de corpo dos pré-molares superiores em direção ao primeiro molar distalizado. Essa distalização espontânea dos pré-molares de corpo explica-se pela ação das fibras transeptais ${ }^{10,26,30,54,90,117,130}$. As fibras transeptais consistem em fibras colágenas que se inserem no cemento de um dente a outro, ligandoos mesiodistalmente. A partir da existência de um espaço entre dois dentes, por exemplo, o espaço obtido pela distalização dos molares superiores, essas fibras são distendidas e tendem a movimentar ambos os dentes adjacentes, de maneira a fechar o espaço interdentário. Como o primeiro molar superior em questão encontrava-se em contenção com o Botão de Nance e o aparelho extrabucal, de uso noturno, a ação dessas fibras concentrou-se apenas nos segundos pré-molares, que foram distalizados em direção ao espaço obtido pela distalização dos molares superiores. Também em decorrência dessas fibras transeptais, os primeiros pré-molares acompanharam o movimento para distal dos segundos pré-molares superiores, verificado no presente estudo.

Observou-se neste estudo que, para alguns pacientes, essa distalização dos primeiros pré-molares superiores aconteceu parcialmente, mas para $43,47 \%$ da amostra notou-se clinicamente a completa distalização espontânea dos pré-molares superiores para uma relação de Classe I de pré-molares de Andrews, tornando desnecessária a realização da retração 
mecânica desses dentes, vindo a facilitar bastante a finalização do tratamento ortodôntico.

Todavia, não existem relatos na literatura explicando quais os determinantes para a ocorrência de uma completa distalização espontânea dos pré-molares, como ocorreu em 43,47\% dos pacientes da amostra analisada. No presente estudo, tentou-se uma correlação entre este fato e o padrão de crescimento facial, mas o número diminuto de pacientes com características verticais impossibilitou a obtenção de uma significância estatística. Apenas a critério de observação, notourse que do total dos 10 pacientes (43,47\% da amostra) em que ocorreu a distalização completa dos pré-molares, $60 \%$ possuíam um padrão de crescimento preponderantemente horizontal e $40 \%$, vertical. Para conclusões mais expressivas, sugere-se a realização de estudos futuros empregando amostras maiores.

\section{Primeiro molar superior}

A partir dos dados obtidos no presente estudo, verificou-se uma mesialização estatisticamente significante do primeiro molar superior de 1,208mm, confirmada pelo aumento da distância linear CM-PTV (figura 24 pg 142), o que nos leva à conclusão imediata da recidiva e do fracasso da mecanoterapia empregada. Entretanto, HILGERS ${ }^{70}$, em 1992, quando introduziu o aparelho Pendulum, atentou para a necessidade da sobrecorreção, pois se tratando de uma distalização obtida em grande parte pelo movimento de inclinação das coroas, deve-se esperar uma recidiva de aproximadamente 20 a $30 \%$ durante a verticalização dos molares distalizados.

Também GIANELLY56, em 1998, preconizou uma sobrecorreção de aproximadamente $2 \mathrm{~mm}$, devido principalmente à maior movimentação para mesial das coroas comparada às raízes durante a verticalização do molar e da perda de ancoragem que invariavelmente 
acontece na retração dos pré-molares (quando necessária), dos caninos e dos incisivos superiores.

Dessa forma, vê-se que uma certa mesialização do primeiro molar superior já era esperada, vista a significativa verticalização de $7,63^{\circ}$ que esses dentes sofreram.

Contudo, NGANTUNG; NANDA; BOWMAN ${ }^{99}$, em 2001, encontraram uma mesialização ainda maior do primeiro molar superior entre o período pós-distalização por meio do Distal Jet e o término do tratamento ortodôntico e, até mesmo, da fase inicial comparada ao final do tratamento. Esses resultados assustam principalmente o clínico, tratando-se de uma terapia distalizadora de molares superiores para o tratamento da Classe II. Considerando-se que todos os pacientes finalizaram o tratamento em uma relação de molares e de caninos em Classe I, os autores afirmaram que, na verdade, essa mesialização ocorreu às expensas do próprio crescimento do paciente, que também promoveu um movimento mesial do primeiro molar inferior. Ou seja, durante a correção da relação molar de Classe II, interrompeu-se a compensação dentoalveolar, permitindo uma nova relação molar. Após a correção, a maxila e a mandíbula continuaram o seu crescimento anterior normal, sendo acompanhadas conseqüentemente pelos molares superiores e inferiores. Resultados semelhantes foram verificados por CANGIALOSI et al. ${ }^{32}$ na comparação do período inicial ao final do tratamento ortodôntico fixo, com a distalização prévia dos molares superiores com o aparelho extrabucal, tração cervical.

Assim, esta mesialização dos molares superiores observada no presente estudo, segundo as observações dos autores acima ${ }^{32,99}$, deveut se ao crescimento anterior da maxila, visto que em todos os pacientes verificourse a permanência da relação molar de Classe I no momento da segunda tomada radiográfica. Todavia, provavelmente este não seja um fato solitário já que o período de tempo analisado neste estudo apresentourse menor (12 meses) comparado aos estudos anteriormente citados (1999 e 32 meses $^{32}$, respectivamente). 
O fato do ângulo SNA haver diminuído neste estudo, porém não estatisticamente significante, não inviabiliza esta possibilidade, pois o crescimento efetivo para anterior da maxila não deve ser avaliado utilizando como referência o ponto Násio, visto que o mesmo se desloca para anterior concomitantemente ao ponto $\mathrm{A}$ durante $\mathrm{o}$ crescimento, mascarando muitas vezes, o crescimento maxilar real ${ }^{32}$. Para avaliar esta alteração ânteroposterior maxilar seria mais adequada uma medida linear como PTV-A, que usa como referencial a fissura pterigomaxilar, utilizada por NGANTUNG; NANDA; BOWMAN ${ }^{99}$, onde detectou-se um movimento anterior significativo da maxila, logicamente acompanhado pelos molares superiores.

Apesar da possibilidade da mesialização dos molares superiores se dever ao crescimento do paciente, não interferindo no sucesso da mecanoterapia; ou pela verticalização das raízes do primeiro molar superior, não há como ignorar a possibilidade da simples perda de ancoragem, ou seja, a recidiva, pela característica altamente instável dos molares distalizados. ${ }^{56,70}$

Os aparelhos de contenção são ressaltados como essenciais na mecânica distalizadora de molares superiores por todos os autores. GIANELL ${ }^{66}$, em 1998, afirmou que os molares distalizados possuem uma alta tendência de recidivar, particularmente na presença dos segundos molares superiores irrompidos. ANDREASEN, NAESSIG ${ }^{6}$ notaram uma recidiva de $90 \%$ em uma semana, em molares superiores distalizados por meio do aparelho extrabucal, sem o uso de qualquer tipo de contenção. Devido a isso, instalourse o Botão de Nance nos pacientes analisados neste estudo. Em decorrência da recomendação de alguns autores para a utilização do aparelho extrabucal, de uso noturno $33,34,36,47,57,67,90,104,115,123$, esse recurso foi empregado também, de maneira a contribuir na contenção.

Verificou-se a característica instável dos molares distalizados e a necessidade da presença do aparelho de contenção naqueles pacientes que fraturaram o Botão de Nance durante o tratamento e que somente procuraram por auxílio do profissional responsável transcorridos 
aproximadamente 15 dias, já que constatou-se uma recidiva parcial da relação molar de Classe II, o que inviabilizou a participação desses pacientes na amostra deste estudo. Assim, deve-se atentar durante 0 tratamento ortodôntico pós-distalização dos molares superiores, para a orientação e conscientização dos pacientes, como também a constante vigilância do profissional nas condições do aparelho de contenção.

A perda de ancoragem observada pode representar uma ineficácia parcial do Botão de Nance para a contenção total dos molares distalizados, como também uma cooperação duvidosa dos pacientes no uso noturno do aparelho extrabucal. Contudo, essa mesialização dos molares não comprometeu o tratamento ortodôntico até o presente, visto que todos os pacientes se encontram com a relação molar de Classe I.

Porém, a problemática da perda de ancoragem torna-se mais preocupante durante a retração dos dentes ântero-superiores ${ }^{56,70,113,99}$, em que pode ser necessária a utilização de reforços de ancoragem como o uso do aparelho extrabuca ${ }^{34,36,47,56,59,67,90,104,108,115,123}$ e/ou dos elásticos de Classe II ${ }^{34,54,104,106 .}$

Portanto, diante da mesialização do primeiro molar superior distalizado seja pelo crescimento maxilar, pela verticalização das suas raízes ou pela recidiva, a melhor forma de tratamento consiste na prevenção dessas intercorrências com a obtenção da sobrecorreção de aproximadamente $2 \mathrm{~mm}$, a fim de garantir a finalização do tratamento ortodôntico com sucesso. 


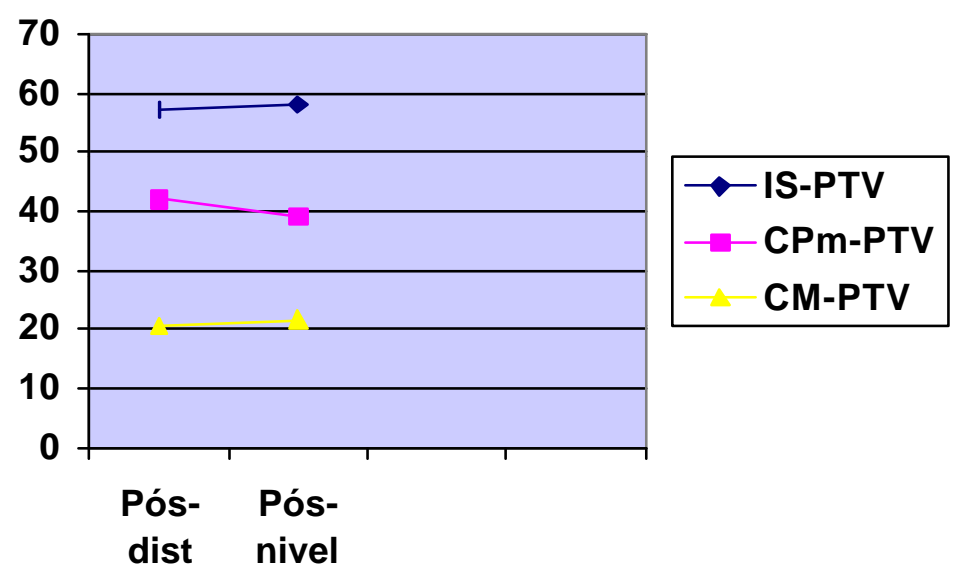

Figura 24 - Alterações dentárias sagitais

\section{6 - EFEITOS PÓS-DISTALIZAÇÃO NO PERFIL MOLE}

A perda de ancoragem ocorrida durante a distalização dos molares superiores promove a protrusão e vestibularização dos incisivos superiores. Conseqüentemente, nota-se uma protrusão estatisticamente significante dos lábios superior e inferior $29,49,52$.

Já no tratamento ortodôntico com aparelho fixo posterior à distalização molar, verificourse neste estudo que houve a reversão parcial deste efeito, com a retrusão estatisticamente significante do lábio superior de $0,815 \mathrm{~mm}$ (figura 25). Este dado apresenta-se concernente ao obtido por NGANTUNG; NANDA; BOWMAN ${ }^{99}$, em 2001, em que se observou uma melhora bastante significativa do perfil facial ao final do tratamento ortodôntico com aparelho fixo.

O aumento obtido no presente estudo da medida E-Ls, que representa a retrusão do lábio superior, provavelmente deveu-se a um crescimento do nariz e/ou mento, provocando um movimento para anterior da linha E. Isso porque não houve a retrusão dos incisivos superiores, 
representada pela medida linear PTV-IS, ocorrendo somente uma suave inclinação lingual $\left(1,36^{\circ}\right)$, não significante estatisticamente.

Um fator que comprovou que esse aumento na medida E-Ls não se deveu a uma retrusão verdadeira do lábio superior, mas sim devido ao crescimento do nariz e mento, constituiu-se na alteração não significante estatisticamente do ângulo nasolabial (figura 25). Como o ângulo nasolabial não se alterou no período avaliado, conclui-se que o lábio superior também não sofreu modificações sagitais no seu posicionamento no período analisado. Este fato vem confirmar a ocorrência do crescimento do nariz e/ou do mento, reponsáveis pelo aumento da grandeza E-Ls.

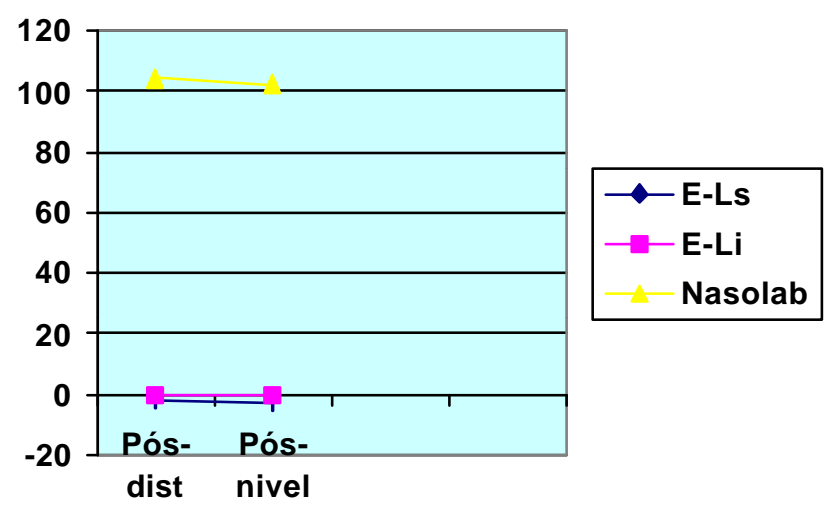

Figura 25 - Alterações no perfil mole

O lábio inferior não apresentou alteração significativa (figura 25), dado já esperado, visto que vários pacientes da amostra não se encontravam com o aparelho ortodôntico fixo instalado no arco dentário inferior no momento da segunda tomada radiográfica. 


\section{7 - CONSIDERAÇÕES CLÍNICAS}

A má oclusão de Classe II apresenta-se de diversas formas na população, podendo possuir comprometimento esquelético (protrusão maxilar e/ou retrusão mandibular) ou não ${ }^{17,96}$. Segundo MOYERS et al ${ }^{96}$; CETLIN; TEN HOEVE ${ }^{35}$ e GIANELLY ${ }^{56}$ para a Classe II dentária, sem comprometimentos esqueléticos significativos, o tratamento mais indicado consiste na distalização dos molares superiores, com a posterior retração dos pré-molares, dos caninos e dos incisivos superiores para uma relação oclusal normal.

Para a realização do tratamento distalizador de molares superiores há na literatura muitos aparelhos disponíveis, alguns que requerem uma alta cooperação dos pacientes, como: o aparelho extrabucal ${ }^{40,82,83}$, o arco de Wilson $67,98,128$, a placa removível $A C C O^{35,53,76}$, dentre outros.

Contudo, a cooperação dos pacientes em Ortodontia apresenta-se incerta e imprevisíve ${ }^{38,94}$. Em decorrência disso, vários autores procuraram desenvolver mecânicas e aparelhos intrabucais (sem acometimento estético) que independem da colaboração dos pacientes, como: os magnetos repelentes ${ }^{58,59,72}$, as molas de $\mathrm{NiTi}^{50,57,104}$, os fios de $\mathrm{NiTi}^{54,77,86,90}$, o Distal Jet $\mathrm{t}^{25,26,34,99,107}$, o aparelho de Nance modificado ${ }^{106,108}$, o Jones Jig 67,76,115,121,121,123, o aparelho Pendulum 29,30,31,36,49,52,70,87, etc.

O aparelho Pendulum destaca-se por sua facilidade de confecção e instalação, além da sua eficiência na correção da relação molar de Classe $\|^{29,30,31,36,49,52,70,87}$. Porém, devido a sua introdução relativamente recente na literatura, não há estudos analisando o comportamento das estruturas dentárias, esqueléticas e tegumentares durante o tratamento ortodôntico fixo, fato que nos impulsionou a realizar o presente trabalho.

Os resultados obtidos apresentaram-se bastante promissores, com uma verticalização significativa dos primeiros molares e primeiros prémolares superiores, que refletiu uma estabilidade dos seus posicionamentos; 
adicionada a uma distalização espontânea dos pré-molares superiores, completa em $43,47 \%$ da amostra, que veio a facilitar muito a continuidade da terapia ortodôntica fixa.

Vale ressaltar que os procedimentos realizados até o momento caracterizam-se como de fácil confecção, visto que apenas foram instalados o Botão de Nance e o aparelho extrabucal, ambos de uso corriqueiro em Ortodontia, além do aparelho ortodôntico fixo, numa fase sem qualquer dificuldade para realização clínica, ou seja, durante o alinhamento e nivelamento do arco dentário superior.

Outra observação importante consiste na conscientização dos pacientes da necessidade da rápida procura do profissional responsável na ocorrência de qualquer fratura do Botão de Nance, utilizado como forma de contenção. Dos pacientes em tratamento, três fraturaram o Botão de Nance e somente informaram o profissional transcorridos pelo menos 15 dias, o que levou à recidiva parcial da relação molar de Classe II. Dessa forma, observourse que uma pequena colaboração dos pacientes ainda faz-se necessária, como também no uso noturno do aparelho extrabucal.

Apesar da discreta mesialização dos primeiros molares superiores avaliada neste estudo, essa não comprometeu os resultados da terapia distalizadora por meio do aparelho Pendulum, já que os pacientes encontravam-se, no momento da segunda tomada radiográfica analisada, com uma relação molar de Classe I.

Todavia, o sucesso da terapêutica distalizadora de molares superiores correlaciona-se fundamentalmente a uma finalização satisfatória do tratamento ortodôntico fixo. Devido a isso, torna-se de suma importância a realização de estudos futuros para a análise do comportamento do complexo craniofacial na finalização do tratamento ortodôntico, principalmente com relação ao posicionamento ântero-posterior do primeiro molar superior após a realização da retração ântero-superior que, 
provavelmente, necessitará de um reforço de ancoragem como o aparelho extrabucal e/ou o uso de elásticos de Classe II. 


\section{CONCLUSÕES}




\section{CONCLUSÕES}

Com base nos resultados obtidos no período compreendido entre a remoção do aparelho Pendulum e o término do alinhamento e nivelmento do arco dentário superior, torna-se lícito concluir que:

\section{1) Com relação aos aspectos esqueléticos:}

1.1) não houve alteração estatisticamente significante do posicionamento ântero-posterior da maxila e da mandíbula, ou seja, a mecanoterapia empregada não afetou significantemente ambos os maxilares,

1.2) notoutse a melhora da relação sagital intermaxilares, representada pela grandeza angular ANB, que diminuiu 0,521ํ, estatisticamente significante, devido a uma restrição do crescimento anterior da maxila, provocado pelo uso noturno do aparelho extrabucal e, pelo crescimento mandibular simultâneo, que juntos alcançaram significância estatística;

1.3) o padrão de crescimento facial permaneceu estável, como também a mandíbula não apresentou qualquer alteração rotacional;

1.4) a altura facial ântero-inferior aumentou em $0,887 \mathrm{~mm}$, estatisticamente significante, em decorrência do crescimento vertical facial normal. 


\section{2) Com relação aos aspectos dentários:}

2.1)os incisivos superiores extruíram 0,51mm, estatisticamente significante;

2.2) apesar de não extruírem, os primeiros pré-molares superiores verticalizaram $10,23^{\circ}$ e distalizaram espontaneamente 2,86mm, ambos com significância estatística, em conseqüência da verticalização das suas raízes e da ação das fibras transeptais;

2.3) verificourse, em $43,47 \%$ dos pacientes, uma completa distalização espontânea dos pré-molares superiores para uma relação de Classe I de Andrews;

2.4) os primeiros molares superiores extruíram 0,739mm, verticalizaram $7,63^{\circ}$ e mesializaram 1,208mm. Esta mesialização ocorreu devido à associação dos seguintes fatores: verticalização das suas raízes, provável crescimento maxilar para anterior e a uma suave recidiva do movimento distalizador;

2.5) até o presente, essa mesialização dos primeiros molares superiores não inviabilizou o procedimento, visto que todos os pacientes se encontram numa relação molar de Classe I.

\section{3) Com relação aos efeitos tegumentares:}

3.1) o perfil mole permaneceu relativamente estável, sendo que apenas observourse uma retrusão estatisticamente significante do lábio superior em $0,81 \mathrm{~mm}$. 


\section{4) Com relação aos efeitos adversos e seu controle:}

4.1) a melhor forma de prevenir o fracasso da terapêutica distalizadora, pela mesialização dos molares distalizados durante 0 tratamento ortodôntico fixo, consiste no emprego de aparelhos de contenção e na obtenção prévia de sobrecorreção aproximada de 2mm;

4.2) a grande maioria dos efeitos adversos promovidos pelo aparelho Pendulum, ou seja, inclinação por distal dos primeiros molares superiores; mesialização e inclinação por mesial dos prémolares; intrusão dos primeiros molares superiores e protrusão do lábio superior; foi corrigida durante a terapia ortodôntica fixa. 


\section{REFERÊNCIAS BIBLIOGRÁFICAS}




\section{REFERÊNCIAS BIBLIOGRÁFICAS*}

1 - ALLAN, T.K.; HODGSON, E. W. The use fo personality measurements as a determinant of patient cooperation in na orthodontic practice. Amer. J. Orthodont., v.54, n. 6, p.433-40, June 1968.

2 - ALMEIDA, R.R.; ALMEIDA, M.R.; INSABRALDE, C.M.B. Um método alternativo de tratamento para a correção da Classe II de Angle utilizando o aparelho Jones Jig. Relato de um caso clínico. Rev. dent. Press Ortod. Ortop. Facial, v.4, n.4, jul./ago. 1999.

3 - ALMEIDA, R.R. et al. Modificação do aparelho Pendulum/Pend-X. Descrição do aparelho e técnica de construção. Rev. dent. Press Ortod. Ortop. Facial, v.4, n.6, p.12-9, nov./dez. 1999.

4 - ANDERSON, D.L.; POPOVICH, F. Lower cranial heigh vs craniofacial dimension in Angle class II malocclusion. Angle Orthodont., v.53, n.3, p.253-60, July 1983.

5 - ANDERSON, G.M. On the diagnosis and treatment of "distocclusion". Amer. J. Orthodont. oral Surg., v.32, n.2, p.88-94, Feb. 1946.

6 - ANDREASEN, G.; NAESSIG, C. Experimental findings on mesial relapse of maxillary first molars. Angle Orthodont., v.38, n.1, p.51-5, Jan. 1968.

7 - ANGLE, E. H. Classification of malocclusion. Dent. Cosmos, v.41, p.24664, 1899.

\footnotetext{
* Normas recomendadas para uso no âmbito da Universidade de São Paulo, com base no documento "Referências Bibliográficas: exemplos", emanado do Conselho Supervisor do Sistema Integrado de Bibliotecas da USP, em reunião de 20 de setembro de 1990.
} 
8 - ANGLE, E.H. Treatment of malocclusion of the teeth and fractures of the maxilla, Angle"s system. $7^{\text {th }}$ ed. Philadelphia: SS White Dental Mfg. Co., 1907. apud PROFFIT, W.R. Forty-year review of extraction frequencies at a university orthodontic clinic. Angle Orthodont., v.64, n.6, p.407-14, June 1994.

9 - ARAS, A. Class II correction with the modified sagittal appliance and maxillary second molar extraction. Angle Orthodont., v.70, n.4, p.332-8, Aug. 2000.

10 - ARMSTRONG, N.M. Controlling the magnitude, duration and direction of extra oral force. Amer. J. Orthodont., v.59, n.3, p.217-43, Mar. 1971.

11 - ARVYSTAS, M.G. Nonextraction treatment of Class II, division 1 malocclusions. Amer. J. Orthodont., v.88, n.5, p.380-95, Nov. 1985.

12 - BASDRA, E. K.; STELLZIG, A..; KOMPOSCH, G. A clinical report for distalizing maxillary molars by using superelastic. J. Orofac. Orthop., v.57, n.2, p.118-23, Apr. 1996.

13 - BATTSTRÖM, V.; INGELSSON, M.; ABERG, E. Treatment co-operation in orthodontic patients. Brit. J. Orthodont., v.18, n.1, p.37-41, Feb. 1991.

14 - BAUMRIND, S. et al. Quantitative analysis of the orthodontic and orthopedic effects of maxillary traction. Amer. J. Orthodont. , v.84, n.5, p.384-98, Nov. 1983.

15 - BERNSTEIN, L. Treatment of Class II, division 1 maximum anchorage cases with the ACCO appliance. J. clin. Orthodont., v.4, n.7. p.374-83, July 1970 . 
16 - BISHARA, S. E. et al. Dentofacial and soft tissue changes in Class II, division 1 cases treated with and without extractions. Amer. J. Orthodont. Dentofac. Orthop., v.107, n.1, p.28-37, Jan. 1995.

17 - BISHARA, S.E. et al. Changes in dentofacial structures in untreated Class II division 1 and normal subjects: a longitudinal study. Angle Orthodont., v.67, n.1, p.55-66, Jan. 1997.

18 - BLECHMAN, A.M. Magnetic force systems in orthodontics. Amer. J. Orthodont., v.87, n.3, p.201-10, Mar. 1985.

19 - BLECHMAN, A.M. Pain-free and mobility-free orthodontics? Amer. J. Orthodont. Dentofac. Orthop. , v.113, n.4, p.379-83, Apr. 1998.

20 - BLECHMAN, A.M.; SMILEY, H. Magnetic force in orthodontics. Amer. J. Orthodont., v.74, n.4, p.435-43, 1978.

21 - BLECHMAN, A.M.; STEGER, E.R. A possible mechanism of action of repelling, molar distalizing magnets. Amer. J. Orthodont. Dentofac. Orthop., v.108, n.4, p.428-31, Oct. 1995.

22 - BONDEMARCK. L. et al. Author"s response: repelling magnets versus superelastic nickel-titanium coils. Angle Orthodont.,v.65, n.1, p.810, Jan. 1995.

23 - BONDEMARCK, L., KUROL, J. Distalization of maxillary first and second molars simultaneously with repelling magnets. Europ. J. Orthodont., v.14, n.4, p.264-72, Aug. 1992.

24 - BONDEMARCK, L.; KUROL, J.; BERNHOLD, M. Reppeling magnets versus superelastic nickel-titanium coils in simultaneous distal movement of maxillary first and second molars. Angle Orthodont., v.64, n.3, p.189-98, Mar. 1994. 
25 - BOWMAN, S. J. Modifications of the Distal Jet. J. clin. Orthodont., v.32, n.9, p.549-56, Sept. 1998.

26 - BOWMAN, S.J. Class II combination therapy. J. clin. Orthodont., v.32, n.10, p.611-20, Oct. 1998.

27 - BROEKMAN, R. W. The cooperation of patients in orthodontic treatment. Oral Res., v.4, p.432, 1969. /Abstract/

28 - BURSTONE, C.J. Beta titanium: a new orthodontic alloy. Amer. J. Orthodont., v.77, n.2, p.121-32, Feb. 1980.

29 - BUSSICK, T.J.; Mc NAMARA JUNIOR, J.A. Dentoalveolar and skeletal changes associated with the pendulum appliance. Amer. J. Orthodont. Dentofac. Orthop., v.117, n.3, p.333-43, Mar. 2000.

30 - BYLOFF, F. K.; DARENDELILER, M. A. Distal molar movement using the pendulum appliance. Part 1: clinical and radiological evaluation. Angle Orthodont., v.67, n.4, p.249-60, Apr. 1997.

31 - BYLOFF, F. K. et al. Distal molar movement using the pendulum appliance. Part 2: The effects of maxillary molar root uprighting bends. Angle Orthodont., v.67, n.4, p.261-70, Apr. 1997.

32 - CANGIALOSI, T.J. et al. A cephalometric appraisal of edgewise Class II nonextraction treatment with extraoral force. Amer. J. Orthodont. Dentofac. Orthop., v.93, n.4, p.315-24, Apr. 1988.

33 - CARANO, A.; TESTA, M.; SICILIANI, G. The lingual distalizer system. Europ. J. Orthodont., v.18, n.5, p.445-8, Oct. 1996.

34 - CARANO, A.; TESTA, M. The distal jet for upper molar distalization. J. clin. Orthodont., v.30, n.7, p.374-80, July 1996.

35 - CETLIN, N. M., TEN HOEVE, A. Nonextraction treatment. J. clin. Orthodont., v.17, n.6, p.396-413, June 1983. 
36 - CHAQUÉS-ASENSI, J.; KALRA, V. Effects of the pendulum appliance on the dentofacial complex. J. clin. Orthodont., v.35, n.4, p.254-7, Apr. 2001.

37 - CHUA, A.; LIM, J.Y.S.; LUBIT, E.C. The effects of extraction versus nonextraction orthodontic treatment on the growth of the lower anterior face height. Amer. J. Orthodont. Dentofac. Orthop., v.104, n.4, p.361-8, Oct. 1993.

38 - ClEMMER, E.J.; HAYES, E.W. Patient cooperation in wearing orthodontic headgear. Amer. J. Orthodont., v.75, n.5, p.517-24, May 1979.

39 - DORSEY, J.; KORABIK, K. Social and psychological motivations for orthodontic treatment. Amer. J. Orthodont., v.72, n.4, p.460, Oct. 1977.

40 - DUGONI, S. A.; CHEE, S.O.L.; HARNICK, D.J. Mixed-dentition treatment. Amer. J. Orthodont. Dentofac. Orthop., v.101, n.6, p.501-8, June 1992.

41 - ELMS, T.N.; BUSCHANG, P.H.; ALEXANDER, R.G. Long-term stability of Class II, division 1, nonextraction cervical face-bow therapy: I . Model analysis. Amer. J. Orthodont. Dentofac. Orthop., v.109, n.3, p.271-6, Mar. 1996.

42 - ELMS, T.N.; BUSCHANG, P.H.; ALEXANDER, R.G. Long-term stability of Class II, division 1, nonextraction cervical face-bow therapy: II. Cephalometric analysis. Amer. J. Orthodont. Dentofac. Orthop., v.109, n.4, p.386-92, Apr. 1996.

43- ENLOW, D.H.; KURODA, T.; LEWIS, A.B. The morphological and morphogenetic basis for craniofacial form and pattern. Angle Orthodont., v.41, n.3, p.161-88, July 1971. 
44 - ERVERDI, N., KOYUTÜRK, Ö., KÜÇÜKKELES, N. Nickel-titanium coil springs and repelling magnets: a comparison of two different intraoral molar distalization techniques. Brit. J. Orthodont., v.24, n.1, p.47-53, Feb. 1997.

45 - FERRO, F.; MONSURRÓ, A.; PERILLO, L. Sagittal and vertical changes after treatment of Class II division 1 malocclusion according to the Cetlin method. Amer. J. Orthodont. Dentofac. Orthop., v.118, n.2, p.150-8, Aug. 2000.

46 - FIDLER, B.C. et al. Long-term stability of Angle Class II, division 1 malocclusions with successful occlusal results at end of active treatment. Amer. J. Orthodont. Dentofac. Orthop., v.107, n.3, p.276-85, Mar. 1995.

47 - Figueiredo, C. T. P., Figueiredo, M. A., NOBUyASU, M. Distalização de molares superiores com 0 aparelho Pendulum/Pendex. Rev. Ass. paul. cirurg. Dent., v.53, n.1, p.2730, jan./fev. 1999.

48 - FORTINI, A.; LUPOLI, M.; PARRI, M. The first class appliance for rapid molar distalization. J. clin. Orthodont., v.33, n.6, p.322-8, June 1999.

49 - FUZIY, A. Estudo das alterações sagitais, verticais e transversais decorrentes da distalização dos molares superiores com 0 aparelho Pendulum. Bauru, 2001. 255p. Tese (Doutorado) Faculdade de Odontologia de Bauru, Universidade de São Paulo.

50 - GHAFARI, J. Modified nance and lingual appliances for unilateral tooth movement. J. clin. Orthodont., v.19, n.1, p.30-3, Jan. 1985.

51 - GHOSH, J.; NANDA, R. S. Class II, division 1 malocclusion treated with molar distalization therapy. Amer. J. Orthodont. Dentofac. Orthop., v.110, n.6, p.672-7, Dec. 1996. 
52 - GHOSH, J.; NANDA, R. S. Evaluation of na intraoral maxillary molar distalization technique. Amer. J. Orthodont. Dentofac. Orthop., v.110, n.6, p.639-46, Dec. 1996.

53 - GIANCOTTI, A. Nonextraction treatment of a high-angle class II malocclusion: a case report. Amer. J. Orthodont. Dentofac. Orthop., v.117, n.6, p.721-7, June 2000.

54 - GIANCOTTI, A.; COZZA, P. Nickel titanium double-loop system for simultaneous distalization of first and second molars. J. clin. Orthodont., v.32, n.4, p.255-60, Apr. 1998.

55 - GIANELLY, A. A. JCO Interviews. J. clin. Orthodont., v.30, n.8, p.43946, Aug. 1996.

56 - GIANELLY, A.A. Distal movement of the maxillary molars. Amer. J. Orthodont. Dentofac. Orthop., v.114, n.1, p.66-72, July 1998.

57 - GIANELLY, A. A.; BEDNAR, J.; DIETZ, V. Japanese NiTi coils used to move molars distally. Amer. J. Orthodont. Dentofac. Orthop., v.99, n.6, p.564-6, June 1991.

58 - GIANELLY, A. A., VAITAS, A. S., THOMAS, W. M. The use of magnets to move molars distally. Amer. J. Orthodont. Dentofac. Orthop., v.96, n.2, p.161-7, Aug. 1989.

59 - GIANELLY, A. A. et al. Distalization of molars with repelling magnets. J. clin. Orthodont., v.22, n.1, p.40-4, Jan. 1988.

60 - GOLDREICH, H.N. et al. Considerações sobre os erros em cefalometria. Rev. dent. Press Ortod. Ortop. Facial., v.3, n.1, p.81-90, jan./fev. 1998.

61 - GRABER, T.M. The role of upper second molar extraction in orthodontics. Amer. J. Orthodont., v.41, n.5, p.354-61, May 1955. 
62 - GRABER, T.M. Maxillary second molar extraction in Class II malocclusion. Amer. J. Orthodont., v.56, n.4, p.331-53, Oct. 1969.

63 - GRABER, T.M.; NEUMANN, B. Aparelhos ortodônticos removíveis combinados. In: Aparelhos ortodônticos removíveis. 2.ed. São Paulo, Medica Panamericana, 1987. Cap. 17, p.613-58.

64 - GREENFIELD, R.L. Fixed piston appliance for rapid Class II correction. J. clin. Orthodont., v.29, n.3, p.174-85, Mar. 1995.

65 - GULATI, S.; KHARBANDA, O.P.; PARKASH, H. Dental and skeletal changes after intraoral molar distalization with sectional jig assembly. Amer. J. Orthodont. Dentofac. Orthop., v.114, n.3, p.319-27, Sept. 1998.

66 - HARNICK, D.J. Case report: class II correction using modified Wilson bimetric distalizing arch and maxillary second molar extraction. Angle Orthodont., v.68, n.3, p.275-80, June 1998.

67 - HAYDAR, S.; ÜNER, O. Comparison of Jones Jig molar distalization appliance with extraoral traction. Amer. J. Orthodont. Dentofac. Orthop., v.117, n.1, p.49-53, Jan. 2000.

68 - HENRIQUES, J.F.C. et al. Estudo longitudinal das características da má oclusão de Classe II, divisão 1 sem tratamento, em jovens brasileiros, leucodermas, por um período médio de 3 anos e 4 meses. Rev. dent. Press Ortod. Ortop. Facial, v.3, n.3, p.52-66, maio/jun. 1998.

69 - HILGERS, J. J. A palatal expansion appliance for non-compliance therapy. J. clin. Orthodont., v.25, n.8, p.491-7, Aug. 1991.

70 - HILGERS, J. J. The Pendulum appliance for class II non-compliance therapy. J. Clin. Orthodont., v.26, n.11, p.706-14, Nov. 1992. 
71 - HITCHCOCK, H. P. A cephalometric description of class II, division 1 malocclusion. Amer. J. Orthodont., v.63, n.4, p.414-23, Apr. 1973.

72 - ITOH, T. et al. Molar distalization with repelling magnets. J. clin. Orthodont., v.25, n.10, p.611-7, Oct. 1991.

73 - JARABAK, J.R. Management of an orthodontic practice, St. Louis, 1965, The C. V. Mosby Company, chapter 7, p. 150-81. apud CLEMMER, E.J.; HAYES, E.W. Patient cooperation in wearing orthodontic headgear. Amer. J. Orthodont. Dentofac. Orthop., v.75, n.5, p.517-24, May 1979.

74 - JECKEL, N.; RAKOSI, T. Molar distalization by intra-oral force application. Europ. J. Orthodont., v.13, n.1, p.43-6, Feb. 1991.

75 - JOHNSON, B.E. Distal movement of the maxillary molar using na active removable appliance and extraoral force: a case report. Quintessence Int., v.25, n.1, p.43-8, Jan. 1994.

76 - JONES, R. D.; WHITE, J. M. Rapid Class II molar correction with an open-coil Jig. J. clin. Orthodont., v.26, n.10, p.661-4, Oct. 1992.

77 - KALRA, V. The K-loop molar distalizing appliance. J. clin. Orthodont., v.29, n.5, p.298-301, May 1995.

78 - KARLSEN, A.T. Craniofacial morphology in children with angle Class II-1 malocclusion with and without deepbite. Angle Orthodont., v.64, n.6, p.437-46, June 1994.

79 - KELES, A.; SAYINSU, K. A new approach in maxillary molar distalization: intraoral bodily molar distalizer. Amer. J. Orthodont. Dentofac. Orthop., v.117, n.1, p.39-48, Jan. 2000. 
79A - KINGSLEY, N.W.M. Orthodontics: na historical review of this origin and evolution. S. 1, Mosby, 1875, v.2, p.492. apud MALTAGLIATI, L.A. et al. Avaliação cefalométrica comparativa da má oclusão de classe II, divisão 1, tratada com ortopedia mecânica e com terapia ortodôntica fixa sem extrações. Ortodontia, v.31, n.1, p.30-44, jan./abr. 1998.

80 - KIRJAVAINEN, M.; KIRJAVAINEN, T.; HAAVIKKO, K. Changes in dental arch dimensions by use of na orthopedic cervical headgear in Class II correction. Amer. J. Orthodont. Dentofac. Orthop., v.111, n.1, p.59-66, Jan. 1997.

81 - KLEIN, P.L. An evaluation of cervical traction on the maxilla and the upper first permanent molar. Angle Orthodont., v.27, n.1, p.61-8, Jan. 1957.

82 - KLOEHN, S. Orthodontics - force or persuasion. Angle Orthodont., v.23, n.1, p.56-66, Jan. 1953.

83 - KREIT, L.H.; BURSTONE, C.; DELMAN, L. Patient cooperation in orthodontic treatment. J. Amer. Coll. Dent., v.35, n.4, p.327-32, Oct. 1968. apud CLEMMER, E.J.; HAYES, E.W. Patient cooperation in wearing orthodontic headgear. Amer. J. Orthodont. Dentofac. Orthop., v.75, n.5, p.517-24, May 1979.

84 - LANGFORD, S.R.; SIMS, M.R. Upper molar root resorption because of distal movement. Report of a case. Amer. J. Orthodont., v.79, n.6, p.669-79, June 1981.

85 - LIMA, R.M.A.; LIMA, A.L. Case report: long-term outcome of Class II division 1 malocclusion treated with rapid palatal expansion and cervical traction. Angle Orthodont., v.70, n.1, p.89-94, Feb. 2000.

86 - LOCATELLI, R. et al. Molar distalization with superelastic NiTi wire. J. clin. Orthodont., v.26, n.5, p.277-9, May 1992. 
87 - MACEDO, D.M.; AIDAR, L.A.A. Uso do Pêndulo de Hilgers: apresentação de um caso clínico. Rev. dent. Press Ortod. Ortop. Facial, v.6, n.1, p.63-71, jan./fev. 2001.

88 - MAGNESS, W.B. Extraction of second molars. J. clin. Orthodont., v.20, n.8, p.519-22, Aug. 1986.

89 - MALTAGLIATI, L.A. et al. Avaliação cefalométrica comparativa da má oclusão de classe II, divisão 1, tratada com ortopedia mecânica e com terapia ortodôntica fixa sem extrações. Ortodontia, v.31, n.1, p.30-44, jan./abr. 1998.

90 - MANDURINO,M.; BALDUCCI, L. Asymmetric distalization with a TMA transpalatal Arch. J. clin. Orthodont., v.35, n.3, p.174-8, Mar. 2001.

91 - MARTINS, D.R. et al. Atlas de Crescimento Craniofacial. São Paulo, Ed. Santos, 1998.

92 - MARTINS, J. C. R.; MelO, A. C. M.; MARTINS, L. P. "Pendex" modificado: um novo aparelho para distalização dos molares superiores no tratamento da má oclusão de Classe II. J. bras. Ortod., v.1, n.4, p.37-43, jul./ago. 1996.

93 - MASSLER, M.; FRANKELL, J.M. Prevalence of malocclusion in children aged 14-18 years. Amer. J. Orthodont., v.37, n.10, p.751-68, Oct. 1951.

94 - Mc DONALD, F.T. The influence of age on patient cooperation in orthodontic treatment. Dent. Abstr., v.18, p.52, 1973.

95 - Mc NAMARA JUNIOR, J. A. Components of class II malocclusion in children 8-10 years of age. Angle Orthodont., v.51, n.3, p.177-202, July 1981. 
96 - MOYERS, R. E. et al. Differential diagnosis of class II malocclusions.

Part 1: Facial types associated with class II malocclusions. Amer. J. Orthodont., v.78, n.5, p.477-94, Nov. 1980.

97 - MUSE, D.S. et al. Molar and incisor changes with Wilson rapid molar distalization. Amer. J. Orthodont. Dentofac. Orthop., v.104, n.6, p.556-65, Dec. 1993.

98 - NACHBAR, A.S. Nonextraction treatment started in the mixed dentition. Amer. J. Orthodont., v.77, n.1, p.98-105, Jan. 1980.

99 - NGANTUNG, V.; NANDA, R.S.; BOWMAN, S.J. Posttreatment evaluation of the distal jet appliance. Amer. J. Orthodont. Dentofac. Orthop., v.120, n.2, p.178-85, Aug. 2001.

100 - O"REILLY, M.T.; NANDA, S.K.; CLOSE, J. Cervical and oblique headgear: a comparison of treatment effects. Amer. J. Orthodont. Dentofac. Orthop., v.103, n.6, p.504-9, June 1993.

101 - OLIVER, B.M. The influence of lip thickness and strain on upper lip response to incisor retraction. Amer. J. Orthodont., v.82, n.2, p.141-8, Aug. 1982.

102 - OPPENHEIM, A. Prognathism from the anthropological and orthodontic viewpoints. Dent. Cosmos, v.70, n.12, p.1170-84, Dec. 1928 apud MALTAGLIATI, L.A. et al. Avaliação cefalométrica comparativa da má oclusão de classe II, divisão 1, tratada com ortopedia mecânica e com terapia ortodôntica fixa sem extrações. Ortodontia, v.31, n.1, p.30-44, jan./abr. 1998.

103 - PANCHERZ,H.; ZIEBER,K.; HOYER, B. Cephalometric characteristics of Class II division 1 and Class II division 2 malocclusions: a comparative study in children. Angle Orthodont., v.67, n.2, p.11120, Feb. 1997. 
104 - PIERINGER, M.; DROSCHL, H.; PERMANN, R. Distalization with a Nance appliance and coil springs. J. clin. Orthodont., v.31, n.5, p.321-6, May 1997.

105 - PROFFIT, W.R. Forty-year review of extraction frequencies at a university orthodontic clinic. Angle Orthodont., v.64, n.6, p.407-14, June 1994.

106 - PUENTE, M. Class II correction with na Edgewise-modified Nance appliance. J. clin. Orthodont., v.31, n.3, p.178-82, Mar. 1997.

107 - QUICK, A.N.; HARRIS, A.M.P. Molar distalization with a modified Distal Jet appliance. J. clin. Orthodont., v.34, n.7, p.419-23, July 2000.

108- REINER, T.J. Modified Nance appliance for unilateral molar distalization. J. clin. Orthodont., v.26, n.7, p.402-4, July 1992.

109 - RENFROE, E. W. A study of the facial patterns associated with Class I, Class II, division 1 and Class II, division 2 malocclusions. Angle Orthodont., v.18, n.1/2, p.12-5, Apr. 1948.

110 - RICKETTS, R. M. Cephalometric synthesis. Amer. J. Orthodont., v.46, n.9, p.647-73, Sept. 1960.

111 - RIEDEL, R.A. The relation of maxillary structures to cranium in malocclusion and in normal occlusion. Angle Orthodont., v.22, n.3, p.142-5, July 1952.

112 - RITTO, A.K. Removable molar distalization splint. J. clin. Orthodont., v.29, n.6, p.396-7, June 1995.

113 - RONDEAU, B. H. M. The pendulum appliance. J. Gen. Orthodont., v.6, n.1, p.22-30, Mar. 1995. 
114 - ROSEMBLUM, R.E. Class II malocclusion: mandibular retrusion or maxillary protrusion? Angle Orthodont., v.65, n.1, p.49-62, Jan. 1995.

115 - RUNGE, M. E.; MARTIN, J. T.; BUKAI, F. Analysis of rapid maxillary molar distal movement without patient cooperation. Amer. J. Orthodont. Dentofac. Orthop., v.115, n.2, p.153-7, Feb. 1999.

116 - SASSOUNI, V.; NANDA, S. Analysis of dentofacial vertical proportions. Amer. J. Orthodont., v.50, n.10, p.801-23, Oct. 1964.

117 - SCUZZO, G.; PISANI, F.; TAKEMOTO, K. Maxillary molar distalization with a modified Pendulum appliance. J. clin. Orthodont., v.33, n.11, p.645-50, Nov. 1999.

118 - SCUZZO, G. et al. The modified Pendulum appliance with removable arms. J. clin. Orthodont., v.34, n.4, p.244-6, Apr. 2000.

119 - SEGURA, A.; FULL, C. A. An alternative approach to distalizing a maxillary molar: case report. J. clin. pediat. Dent., v.21, n.2, p.1057, Winter 1997.

120 - SILVA FILHO, O. G.; FREITAS, S. F.; CAVASSAN, A. O. Prevalência de oclusão normal e má oclusão na dentadura mista em escolares da cidade de Bauru (São Paulo). Rev. Ass. paul. cirurg. Dent., v.43, n.6, p.287-90, nov./dez. 1989.

121 - SILVA FILHO, O.G. et al. Distalizador "Jones Jig": um método alternativo para a distalização de molares superiores. Rev. dent. Press Ortod. Ortop. Facial, v.5, n.4, p.18-26, jul./ago. 2000.

122 - SNODGRASS, D. J. A fixed appliance for maxillary expansion, molar rotation and molar distalization. J. clin. Orthodont., v.30, n.3, p.156-9, Mar. 1996. 
123 - SUGUINO, R.; FURQUIM, L.Z; RAMOS, A.L. O aparelho Jones-Jig. Rev. dent. Press Ortod. Ortop. Facial, v.5, n.3, p.83-116, maio/jun. 2000.

124 - TEnNenbaum, M.; GABRIEL, R. Orthodontic treatment with removable plates and extraoral forces. Trans. Eur. Orthod. Soc., p.199-205, 1973 apud JOHNSON, B.E. Distal movement of the maxillary molar using na active removable appliance and extraoral force: a case report. Quintessence Int., v.25, n.1, p.43-8, Jan. 1994.

125 - TWEED, C.H. A philosophy of orthodontic treatment. Amer. J. Orthodont. oral Surg., v.31, n.2, p.74-103, Feb. 1945.

126 - VALE, D. M. V., MARTINS, D. R. Avaliação cefalométrica das estruturas dento-esqueléticas em jovens portadores de Classe II, div. 1, brasileiros, leucodermas e de origem mediterrânea. Ortodontia, v.20, n.1/2. p.5-17, jan./fev. 1987.

127 - WILSON, R.C. Comment on rapid molar distalization (letter). Amer. J. Orthodont. Dentofac. Orthop., v.107, n.3, p.20A, Mar. 1995.

128 - WILSON, R.C.; WILSON, W.L. Enhanced orthodontics, book 1, concept, treatment and case histories. Denver, Colorado: Rocky Mountain Orthodontics, 1988 apud MUSE, D.S. et al. Molar and incisor changes with Wilson rapid molar distalization. Amer. J. Orthodont. Dentofac. Orthop., v.104, n.6, p.556-65, Dec.. 1993.

129 - WILSON, R.C.; WILSON, W.L. Enhanced orthodontics, book 2, force systems mechanotherapy manual. Denver, Colorado: Rocky Mountain Orthodontics, 1988 apud MUSE, D.S. et al. Molar and incisor changes with Wilson rapid molar distalization. Amer. J. Orthodont. Dentofac. Orthop., v.104, n.6, p.556-65, Dec. 1993. 
130 - WONG, A.M.K.; RABIE, A.B.M.; HÄGG, U. The use of Pendulum appliance in the treatment of Class II malocclusion . Brit. dent. J., v.187, n.7, p.367-70, Oct. 1999. 
ABSTRACT 


\section{ABSTRACT}

\section{Cephalometric evaluation after the Pendulum appliance distalization in patients under fixed orthodontic treatment.}

The Pendulum appliance has been shown to be very effective in maxillary molar distalization for the Class II molar relationship correction. However, many side-effects were observed: upper premolars mesial tipping and mesial movement; lower anterior face height increase and considerable distal tipping of the first molars, turning molar distalization to be instable. The purpose of this study was to determine the correction of this side-effects in 23 patients ( 7 males and 16 females), with an initial mean age of 15 years and 1 month, treated with fixed orthodontic appliance associated with the Nance Button and the headgear appliance for night use. After the removal of the Pendulum appliance and at the refinement of the alignment/levelling (previous to the premolars retraction) cephalometric radiographs were obtained, in the mean period of 1 year. The resulted changes were determined by the Student's $t$ test, for paired data. The ANB angle decreased $0,52^{\circ}$ and the lower anterior face height increased by $0,88 \mathrm{~mm}$. The upper incisors extruded $0,51 \mathrm{~mm}$. The first premolars uprighted $10,23^{\circ}$ and distalized 2,86mm, spontaneously. The first molars extruded $0,73 \mathrm{~mm}$, mesialized $1,2 \mathrm{~mm}$ and uprighted $7,63^{\circ}$. The primary conclusion was the correction of the main side-effects produced by Pendulum appliance on the fixed orthodontic appliance, contributing to the satisfactory finalization of the orthodontic treatment. 
APÊNDICE 


\section{APÊNDICE}

Tabela 3 - Pacientes da amostra - gêneros e idades cronológicas

\begin{tabular}{|c|c|c|c|c|}
\hline Pacientes & Gêneros & $\begin{array}{c}\text { Classificação } \\
\text { da Classe II } \\
\text { (Angle) }\end{array}$ & $\begin{array}{c}\text { Idade ao } \\
\text { final do } \\
\text { Pendulum }\end{array}$ & $\begin{array}{c}\text { Idade no } \\
\text { término } \\
\text { nivelamento } \\
\text { superior }\end{array}$ \\
\hline A.C.V. & $\mathrm{F}$ & Divisão 1 & 14 anos & 15 anos \\
\hline AO. & $\mathrm{F}$ & Divisão 1 & $14 \mathrm{a} 10 \mathrm{~m}$ & $15 a 7 m$ \\
\hline A.L.B. & $\mathrm{F}$ & Divisão 1 & $15 a 9 m$ & $17 a 3 m$ \\
\hline A.F.G. & $\mathrm{F}$ & Divisão 1 & 16anos & $16 \mathrm{a} 11 \mathrm{~m}$ \\
\hline B.H.B. & $\mathrm{F}$ & Divisão 1 & $12 \mathrm{a} 6 \mathrm{~m}$ & $13 a 5 m$ \\
\hline B.D.F. & $M$ & Divisão 1 & $15 a 3 m$ & $15 \mathrm{a} 11 \mathrm{~m}$ \\
\hline C.D. & $\mathrm{F}$ & Divisão 1 & $17 \mathrm{a} 5 \mathrm{~m}$ & $17 \mathrm{a} 11 \mathrm{~m}$ \\
\hline C.P.G. & $\mathrm{F}$ & Divisão 1 & 18 anos & $18 \mathrm{a} 10 \mathrm{~m}$ \\
\hline C.P.R. & $M$ & Divisão 1 & $15 \mathrm{a} 11 \mathrm{~m}$ & $16 \mathrm{a} 10 \mathrm{~m}$ \\
\hline F.N.O. & $M$ & Divisão 1 & $18 \mathrm{a} 1 \mathrm{~m}$ & $18 \mathrm{a} 9 \mathrm{~m}$ \\
\hline F.P.G. & $\mathrm{M}$ & Divisão 1 & $15 a 8 m$ & $16 \mathrm{a} 7 \mathrm{~m}$ \\
\hline H.A.C.P. & $M$ & Divisão 1 & $12 \mathrm{a} 11 \mathrm{~m}$ & $13 a 7 m$ \\
\hline H.M.C. & $\mathrm{M}$ & Divisão 1 & $12 \mathrm{a} 3 \mathrm{~m}$ & $13 a 4 m$ \\
\hline J.C.D. & $\mathrm{F}$ & Divisão 1 & $15 a 10 m$ & 17a 3m \\
\hline L.P. & $\mathrm{F}$ & Divisão 1 & $15 \mathrm{a} 11 \mathrm{~m}$ & $16 a 6 m$ \\
\hline L.Z.I. & $\mathrm{F}$ & Divisão 1 & $13 a 11 m$ & 15anos \\
\hline M.O. & $\mathrm{F}$ & Divisão 1 & $15 a 8 m$ & $16 a 8 m$ \\
\hline N.O. & $\mathrm{F}$ & Divisão 1 & $12 \mathrm{a} 7 \mathrm{~m}$ & $13 a 5 m$ \\
\hline R.O. & $\mathrm{F}$ & Divisão 1 & $14 a 3 m$ & $15 a 3 m$ \\
\hline R.Z.I. & $\mathrm{F}$ & Divisão 1 & $12 \mathrm{a} 2 \mathrm{~m}$ & $13 \mathrm{a} 2 \mathrm{~m}$ \\
\hline S.H. & $\mathrm{F}$ & Divisão 1 & $14 \mathrm{a} 5 \mathrm{~m}$ & $15 \mathrm{a} 4 \mathrm{~m}$ \\
\hline T.G.Q. & $F$ & Divisão 1 & $16 a \mathrm{~mm}$ & 18 anos \\
\hline V.A.S.B. & $M$ & Divisão 2 & $16 a 10 m$ & $17 \mathrm{a} 5 \mathrm{~m}$ \\
\hline
\end{tabular}


Tabela 4 - Grandezas angulares esqueléticas dos pacientes da amostra

\begin{tabular}{|c|c|c|c|c|c|c|c|c|}
\hline $\begin{array}{c}\text { Pacien- } \\
\text { tes }\end{array}$ & $\begin{array}{c}\text { SNA } \\
\text { inicial }\end{array}$ & $\begin{array}{l}\text { SNA } \\
\text { final }\end{array}$ & $\begin{array}{l}\text { SNB } \\
\text { inicial }\end{array}$ & $\begin{array}{l}\text { SNB } \\
\text { final }\end{array}$ & $\begin{array}{c}\text { ANB } \\
\text { inicial }\end{array}$ & $\begin{array}{l}\text { ANB } \\
\text { final }\end{array}$ & $\begin{array}{l}\text { SND } \\
\text { inicial }\end{array}$ & $\begin{array}{l}\text { SND } \\
\text { final }\end{array}$ \\
\hline A.C.V. & 85.5 & 86.9 & 80.2 & 83.2 & 5.3 & 3.7 & 77.1 & 79.4 \\
\hline A 0. & 74.4 & 74.4 & 72.7 & 73.3 & 1.7 & 1.1 & 69.7 & 70.4 \\
\hline A.L.B. & 78.9 & 78.2 & 75.3 & 75.3 & 3.5 & 2.9 & 72.9 & 72.9 \\
\hline A.F.G. & 82.4 & 80.0 & 79.9 & 77.8 & 2.5 & 2.2 & 77.9 & 75.9 \\
\hline B.H.B. & 84.6 & 86.2 & 80.2 & 81.5 & 4.5 & 4.7 & 77.4 & 78.7 \\
\hline B.D.F. & 80.3 & 79.7 & 76.5 & 77.5 & 3.8 & 2.2 & 74.2 & 75.1 \\
\hline C.D. & 82.0 & 78.0 & 77.4 & 73.4 & 4.7 & 4.6 & 75.2 & 71.6 \\
\hline C.P.G. & 80.5 & 81.0 & 75.7 & 75.5 & 4.8 & 5.5 & 74.0 & 73.9 \\
\hline C.P.R. & 80.9 & 81.9 & 74.2 & 74.8 & 6.7 & 7.1 & 72.8 & 73.3 \\
\hline F.N.O. & 83.3 & 82.4 & 76.4 & 76.9 & 6.9 & 5.6 & 74.2 & 74.8 \\
\hline F.P.G. & 82.6 & 83.4 & 78.6 & 79.4 & 4.1 & 4.0 & 78.4 & 79.4 \\
\hline H.A.P. & 78.8 & 77.7 & 73.6 & 76.6 & 5.2 & 1.1 & 72.3 & 75.0 \\
\hline H.M.C. & 81.7 & 83.2 & 78.4 & 79.6 & 3.3 & 3.6 & 75.2 & 76.9 \\
\hline J.C.D. & 79.1 & 79.0 & 75.6 & 76.9 & 3.5 & 2.1 & 75.0 & 76.0 \\
\hline L.P. & 71.5 & 75.4 & 69.4 & 72.7 & 2.1 & 2.7 & 68.0 & 71.2 \\
\hline L.Z.I. & 82.8 & 81.2 & 77.4 & 75.3 & 5.4 & 5.8 & 74.3 & 72.5 \\
\hline M.O. & 79.4 & 80.6 & 75.1 & 75.8 & 4.4 & 4.8 & 73.2 & 73.9 \\
\hline N.O. & 78.3 & 78.6 & 71.0 & 71.4 & 7.3 & 7.3 & 68.4 & 68.8 \\
\hline R.O. & 85.0 & 84.8 & 77.9 & 76.7 & 7.1 & 8.1 & 75.1 & 74.0 \\
\hline R.Z.I. & 84.1 & 82.0 & 77.0 & 76.3 & 7.1 & 5.8 & 74.7 & 74.2 \\
\hline S.H. & 83.5 & 81.0 & 75.9 & 75.3 & 7.6 & 5.7 & 74.2 & 73.4 \\
\hline T.G.Q. & 79.7 & 79.0 & 75.7 & 75.3 & 4.0 & 3.6 & 72.8 & 72.5 \\
\hline V.A.B. & 83.6 & 83.9 & 79.0 & 79.9 & 4.7 & 4.0 & 76.9 & 77.9 \\
\hline
\end{tabular}


Tabela 5 - Grandezas do padrão facial dos pacientes deste estudo

\begin{tabular}{|c|c|c|c|c|c|c|c|c|}
\hline $\begin{array}{c}\text { Pacien- } \\
\text { tes }\end{array}$ & $\begin{array}{l}\text { SN.Go } \\
\text { Gn inic }\end{array}$ & $\left|\begin{array}{c}\text { SN.Go } \\
\text { Gn final }\end{array}\right|$ & $\begin{array}{c}\text { FMA } \\
\text { inicial }\end{array}$ & $\begin{array}{l}\text { FMA } \\
\text { final }\end{array}$ & $\begin{array}{l}\text { SN.Gn } \\
\text { inicial }\end{array}$ & $\begin{array}{c}\text { SN.Gn } \\
\text { final }\end{array}$ & $\begin{array}{c}\text { AFAl } \\
\text { inicial }\end{array}$ & $\begin{array}{l}\text { AFAl } \\
\text { final }\end{array}$ \\
\hline A.C.V. & 32.3 & 29.2 & 26.8 & 24.5 & 67.9 & 65.5 & 65.1 & 67.6 \\
\hline AO. & 40.4 & 40.2 & 32.0 & 33.1 & 70.8 & 70.2 & 62.2 & 62.4 \\
\hline A.L.B. & 34.2 & 33.2 & 24.0 & 20.9 & 68.4 & 68.2 & 61.4 & 59.9 \\
\hline A.F.G. & 27.6 & 30.0 & 23.0 & 22.9 & 65.9 & 67.8 & 62.3 & 62.6 \\
\hline B.H.B. & 29.7 & 28.4 & 18.5 & 18.9 & 65.3 & 64.4 & 62.7 & 63.5 \\
\hline B.D.F. & 28.9 & 29.4 & 16.8 & 17.5 & 65.8 & 66.2 & 58.6 & 60.9 \\
\hline C.D. & 24.8 & 28.0 & 17.8 & 17.3 & 68.8 & 72.5 & 64.0 & 63.4 \\
\hline C.P.G. & 28.7 & 28.6 & 17.5 & 18.3 & 66.8 & 67.4 & 63.3 & 63.4 \\
\hline C.P.R. & 34.0 & 33.3 & 28.7 & 27.3 & 70.8 & 70.7 & 66.6 & 68.8 \\
\hline F.N.O. & 34.9 & 34.1 & 28.5 & 28.4 & 68.4 & 67.8 & 70.8 & 70.9 \\
\hline F.P.G. & 23.9 & 22.7 & 20.7 & 19.0 & 64.6 & 64.3 & 70.9 & 70.6 \\
\hline H.A.P. & 40.0 & 37.6 & 31.3 & 30.7 & 71.5 & 69.0 & 70.7 & 71.0 \\
\hline H.M.C. & 31.1 & 29.1 & 23.2 & 21.2 & 67.4 & 66.1 & 60.4 & 61.3 \\
\hline J.C.D. & 29.0 & 29.0 & 21.3 & 18.6 & 66.8 & 66.9 & 56.5 & 60.7 \\
\hline L.P. & 38.6 & 35.1 & 25.8 & 25.0 & 75.7 & 72.8 & 63.2 & 63.3 \\
\hline L.Z.I. & 31.2 & 33.2 & 23.4 & 24.1 & 67.8 & 70.2 & 60.0 & 59.5 \\
\hline M.O. & 26.2 & 28.3 & 18.3 & 21.0 & 66.2 & 66.7 & 65.5 & 67.1 \\
\hline N.O. & 39.3 & 39.5 & 29.3 & 28.6 & 76.7 & 76.9 & 65.8 & 66.8 \\
\hline R.O. & 37.6 & 38.6 & 31.5 & 31.0 & 70.0 & 70.4 & 76.0 & 76.6 \\
\hline R.Z.I. & 39.4 & 40.0 & 33.0 & 32.1 & 71.6 & 72.6 & 66.6 & 70.4 \\
\hline S.H. & 34.8 & 34.8 & 24.7 & 24.0 & 68.3 & 69.2 & 65.3 & 65.7 \\
\hline T.G.Q. & 34.1 & 34.3 & 22.9 & 22.1 & 71.7 & 71.9 & 64.3 & 64.4 \\
\hline V.A.B. & 17.2 & 17.1 & 11.5 & 12.0 & 61.1 & 60.5 & 55.3 & 57.1 \\
\hline
\end{tabular}


Tabela 6 - Grandezas referentes ao perfil mole dos pacientes da amostra

\begin{tabular}{|c|c|c|c|c|c|c|}
\hline Pacientes & $\begin{array}{c}\text { E-Li } \\
\text { inicial }\end{array}$ & $\begin{array}{l}\text { E-Li } \\
\text { final }\end{array}$ & $\begin{array}{c}\text { nasolabial } \\
\text { inicial }\end{array}$ & $\begin{array}{l}\text { nasolabial } \\
\text { final }\end{array}$ & $\begin{array}{c}\text { E-Ls } \\
\text { inicial }\end{array}$ & $\begin{array}{l}\text { E-Ls } \\
\text { final }\end{array}$ \\
\hline A.C.V. & 3.0 & 3.9 & 95.0 & 97.4 & 0.8 & 0.1 \\
\hline A 0. & 2.8 & 2.8 & 112.9 & 114.1 & 0.3 & "-0.6" \\
\hline A.L.B. & 0.7 & 1.9 & 104.5 & 105.5 & -0.2 & -1.2 \\
\hline A.F.G. & 0.5 & -0.3 & 99.3 & 92.9 & -2.5 & -3.4 \\
\hline B.H.B. & -3.3 & -3.3 & 92.7 & 92.2 & -3.1 & -3.0 \\
\hline B.D.F. & 0.3 & 0.9 & 98.0 & 91.8 & -1.9 & -4.1 \\
\hline C.D. & -1.8 & -0.9 & 91.8 & 85.4 & -3.2 & -3.4 \\
\hline C.P.G. & -1.8 & -2.2 & 122.9 & 120.5 & -1.4 & -2.5 \\
\hline C.P.R. & 3.3 & 3.8 & 98.8 & 97.5 & 0.1 & -1.0 \\
\hline F.N.O. & 0.6 & -0.4 & 94.0 & 90.8 & -0.8 & -1.4 \\
\hline F.P.G. & -4.5 & -5.2 & 113.1 & 117.1 & -3.1 & -3.7 \\
\hline H.A.C.P. & -3.3 & -2.6 & 99.9 & 93.9 & -3.2 & -4.3 \\
\hline H.M.C. & 1.4 & 2.0 & 106.1 & 94.1 & 0.9 & -0.2 \\
\hline J.C.D. & -0.9 & -1.2 & 104.4 & 113.7 & & \\
\hline L.P. & -1.4 & -2.1 & 122.6 & 121.1 & -3.8 & -5.1 \\
\hline L.Z.I. & 1.4 & 0.7 & 92.6 & 100.5 & & \\
\hline M.O. & -3.7 & -3.8 & 101.1 & 98.0 & -3.6 & -4.5 \\
\hline N.O. & 5.1 & 5.7 & 119.9 & 116.7 & 0.5 & -0.6 \\
\hline R.O. & 2.8 & 1.5 & 79.5 & 77.0 & -0.1 & -1.1 \\
\hline R.Z.I. & 5.4 & 5.6 & 97.2 & 102.4 & & \\
\hline S.H. & 0.3 & -0.3 & 117.7 & 106.8 & -0.8 & -1.6 \\
\hline T.G.Q. & -2.7 & -0.2 & 108.3 & 107.4 & -3.9 & -3.8 \\
\hline V.A.S.B. & "-6.3 & "-6.4 & 120.5 & 113.5 & "-6.1 & "-6.0 \\
\hline
\end{tabular}


Tabela 7 - Grandezas verticais, sagitais e das inclinações dos incisivos superiores dos pacientes deste estudo

\begin{tabular}{|c|c|c|c|c|c|c|}
\hline Pacientes & $\begin{array}{l}\text { IS.PP } \\
\text { inicial }\end{array}$ & $\begin{array}{l}\text { IS.PP } \\
\text { final }\end{array}$ & $\begin{array}{l}\text { IS-PP } \\
\text { Inicial }\end{array}$ & $\begin{array}{l}\text { IS-PP } \\
\text { final }\end{array}$ & $\begin{array}{l}\text { PTV-IS } \\
\text { inicial }\end{array}$ & $\begin{array}{c}\text { PTV-IS } \\
\text { final }\end{array}$ \\
\hline A.C.V. & 58.7 & 67.1 & 29.8 & 31.4 & 61.1 & 60.7 \\
\hline AO. & 57.6 & 68.5 & 23.1 & 23.9 & 58.0 & 55.4 \\
\hline A.L.B. & 63.3 & 63.7 & 27.4 & 27.3 & 56.2 & 56.7 \\
\hline A.F.G. & 63.0 & 66.7 & 27.7 & 28.2 & 61.8 & 61.9 \\
\hline B.H.B. & 66.0 & 60.8 & 26.2 & 26.0 & 61.1 & 63.3 \\
\hline B.D.F. & 60.1 & 53.2 & 24.3 & 24.8 & 63.5 & 65.3 \\
\hline C.D. & 69.2 & 57.6 & 29.3 & 28.0 & 55.2 & 57.4 \\
\hline C.P.G. & 72.9 & 75.9 & 27.1 & 26.9 & 56.7 & 55.1 \\
\hline C.P.R. & 63.3 & 70.2 & 29.4 & 29.9 & 54.3 & 54.4 \\
\hline F.N.O. & 76.4 & 66.8 & 31.0 & 30.3 & 61.7 & 64.4 \\
\hline F.P.G. & 71.7 & 69.1 & 27.6 & 27.6 & 54.8 & 55.2 \\
\hline H.A.C.P. & 67.0 & 70.0 & 27.6 & 29.9 & 57.4 & 56.9 \\
\hline H.M.C. & 64.5 & 68.0 & 24.7 & 26.3 & 58.0 & 59.0 \\
\hline \multicolumn{7}{|l|}{ J.C.D. } \\
\hline L.P. & 73.1 & 69.3 & 29.2 & 29.5 & 48.1 & 50.0 \\
\hline \multicolumn{7}{|l|}{ L.Z.I. } \\
\hline M.O. & 70.7 & 71.0 & 29.1 & 29.7 & 57.8 & 57.2 \\
\hline N.O. & 77.1 & 82.3 & 28.2 & 28.3 & 48.3 & 47.3 \\
\hline R.O. & 75.8 & 78.4 & 34.4 & 36.8 & 61.0 & 60.7 \\
\hline \multicolumn{7}{|l|}{ R.Z.I. } \\
\hline S.H. & 68.5 & 67.9 & 27.5 & 29.2 & 56.6 & 56.5 \\
\hline T.G.Q. & 59.3 & 53.4 & 26.2 & 27.1 & 54.4 & 58.4 \\
\hline V.A.S.B. & 85.4 & 56.5 & 23.5 & 22.4 & 58.5 & 64.2 \\
\hline
\end{tabular}


Tabela 8 - Grandezas sagitais, verticais e das inclinações dos primeiros pré-molares superiores dos pacientes desta amostra

\begin{tabular}{c|c|c|c|c|c|c} 
Pacientes & $\begin{array}{c}\text { PP.CPm } \\
\text { inicial }\end{array}$ & $\begin{array}{c}\text { PP.CPm } \\
\text { final }\end{array}$ & $\begin{array}{c}\text { PP-CPm } \\
\text { inicial }\end{array}$ & $\begin{array}{c}\text { PP-CPm } \\
\text { final }\end{array}$ & $\begin{array}{c}\text { PTV-CPm } \\
\text { inicial }\end{array}$ & $\begin{array}{c}\text { PTV-CPm } \\
\text { final }\end{array}$ \\
\hline A.C.V. & 77.2 & 99.1 & 23.6 & 23.6 & 44.6 & 42.7 \\
\hline A O. & 76.0 & 99.6 & 19.8 & 18.2 & 45.1 & 38.4 \\
\hline A.L.B. & 87.5 & 103.8 & 20.0 & 18.4 & 39.6 & 37.5 \\
\hline A.F.G. & 83.1 & 98.8 & 18.9 & 18.8 & 45.5 & 40.0 \\
\hline B.H.B. & 86.3 & 95.5 & 18.9 & 19.6 & 44.9 & 43.1 \\
\hline B.D.F. & 83.6 & 94.0 & 17.9 & 18.7 & 47.3 & 43.1 \\
\hline C.D. & 89.6 & 93.2 & 21.1 & 21.8 & 37.8 & 36.0 \\
\hline C.P.G. & 85.6 & 102.6 & 17.3 & 18.7 & 42.5 & 38.1 \\
\hline C.P.R. & 92.9 & 97.7 & 22.3 & 22.8 & 38.0 & 38.1 \\
\hline F.N.O. & 87.3 & 87.8 & 21.3 & 23.2 & 47.7 & 47.1 \\
\hline F.P.G. & 94.0 & 91.6 & 22.3 & 22.8 & 38.4 & 37.8 \\
\hline H.A.C.P. & 88.8 & 102.2 & 21.7 & 21.4 & 40.7 & 36.2 \\
\hline H.M.C. & 83.0 & 97.4 & 19.1 & 18.5 & 42.8 & 38.6 \\
\hline J.C.D. & & & & & & \\
\hline L.P. & 95.3 & 104.4 & 21.8 & 22.0 & 34.3 & 33.0 \\
\hline L.Z.I. & & & & & & \\
\hline M.O. & 98.0 & 101.1 & 22.3 & 22.5 & 42.6 & 37.9 \\
\hline N.O. & 87.7 & 105.0 & 21.6 & 21.9 & 36.0 & 30.9 \\
\hline R.O. & 92.4 & 106.2 & 27.7 & 28.5 & 44.5 & 42.5 \\
\hline R.Z.I. & & & & & & \\
\hline S.H. & 95.7 & 90.3 & 22.5 & 22.6 & 40.8 & 40.9 \\
\hline T.G.Q. & 86.2 & 96.3 & 20.9 & 21.2 & 39.3 & 36.2 \\
\hline V.A.S.B. & 85.2 & 93.4 & 15.7 & 17.7 & 45.8 & 42.9 \\
\hline & & & & & & \\
\hline
\end{tabular}


Tabela 9 - Grandezas verticais, sagitais e das inclinações dos primeiros molares superiores dos pacientes deste estudo

\begin{tabular}{|c|c|c|c|c|c|c|}
\hline Pacientes & $\begin{array}{l}\text { PP-CM } \\
\text { Inicial }\end{array}$ & $\begin{array}{c}\text { PP-CM } \\
\text { final }\end{array}$ & $\begin{array}{l}\text { PP.CM } \\
\text { inicial }\end{array}$ & $\begin{array}{c}\text { PP.CM } \\
\text { final }\end{array}$ & $\begin{array}{c}\text { PTV-CM } \\
\text { inicial }\end{array}$ & $\begin{array}{c}\text { PTV-CM } \\
\text { final }\end{array}$ \\
\hline A.C.V. & 19.5 & 20.6 & 117.8 & 104.4 & 22.4 & 25.6 \\
\hline A 0. & 16.9 & 15.8 & 116.6 & 104.9 & 22.5 & 23.4 \\
\hline A.L.B. & 15.2 & 15.2 & 112.0 & 102.7 & 18.0 & 21.2 \\
\hline A.F.G. & 13.6 & 14.5 & 117.0 & 110.7 & 23.5 & 25.7 \\
\hline B.H.B. & 17.0 & 17.3 & 105.5 & 100.8 & 22.9 & 24.4 \\
\hline B.D.F. & 14.7 & 15.7 & 113.9 & 102.4 & 25.6 & 26.4 \\
\hline C.D. & 20.1 & 20.2 & 103.4 & 101.2 & 18.8 & 17.3 \\
\hline C.P.G. & 16.2 & 16.4 & 111.4 & 101.8 & 23.0 & 21.9 \\
\hline C.P.R. & 18.5 & 18.8 & 112.2 & 103.2 & 18.3 & 20.1 \\
\hline F.N.O. & 18.2 & 19.9 & 109.9 & 103.5 & 27.3 & 27.5 \\
\hline F.P.G. & 20.1 & 21.2 & 101.3 & 94.0 & 19.2 & 20.5 \\
\hline H.A.C.P. & 15.0 & 17.0 & 116.6 & 113.6 & 17.6 & 19.5 \\
\hline H.M.C. & 15.1 & 15.6 & 116.5 & 110.4 & 20.7 & 22.6 \\
\hline J.C.D. & 15.9 & 16.1 & 112.0 & 102.0 & 18.3 & 21.5 \\
\hline L.P. & 18.5 & 18.8 & 100.7 & 102.2 & 17.0 & 16.5 \\
\hline L.Z.I. & 15.7 & 16.6 & 116.5 & 104.9 & 19.7 & 19.7 \\
\hline M.O. & 19.6 & 17.8 & 116.8 & 116.6 & 17.6 & 16.7 \\
\hline N.O. & 15.7 & 16.8 & 114.8 & 107.9 & 14.5 & 16.0 \\
\hline R.O. & 20.7 & 22.7 & 117.3 & 106.4 & 23.1 & 26.9 \\
\hline R.Z.I. & 17.5 & 21.0 & 112.2 & 105.0 & 18.5 & 20.4 \\
\hline S.H. & 20.4 & 21.3 & 106.1 & 91.3 & 20.7 & 22.4 \\
\hline T.G.Q. & 18.1 & 18.8 & 111.4 & 102.6 & 16.6 & 18.2 \\
\hline V.A.S.B. & 16.1 & 17.2 & 96.6 & 90.5 & 25.8 & 25.0 \\
\hline
\end{tabular}

